\title{
Documentation of Computer Program INFIL3.0 - A Distributed-Parameter Watershed Model to Estimate Net Infiltration Below the Root Zone
}

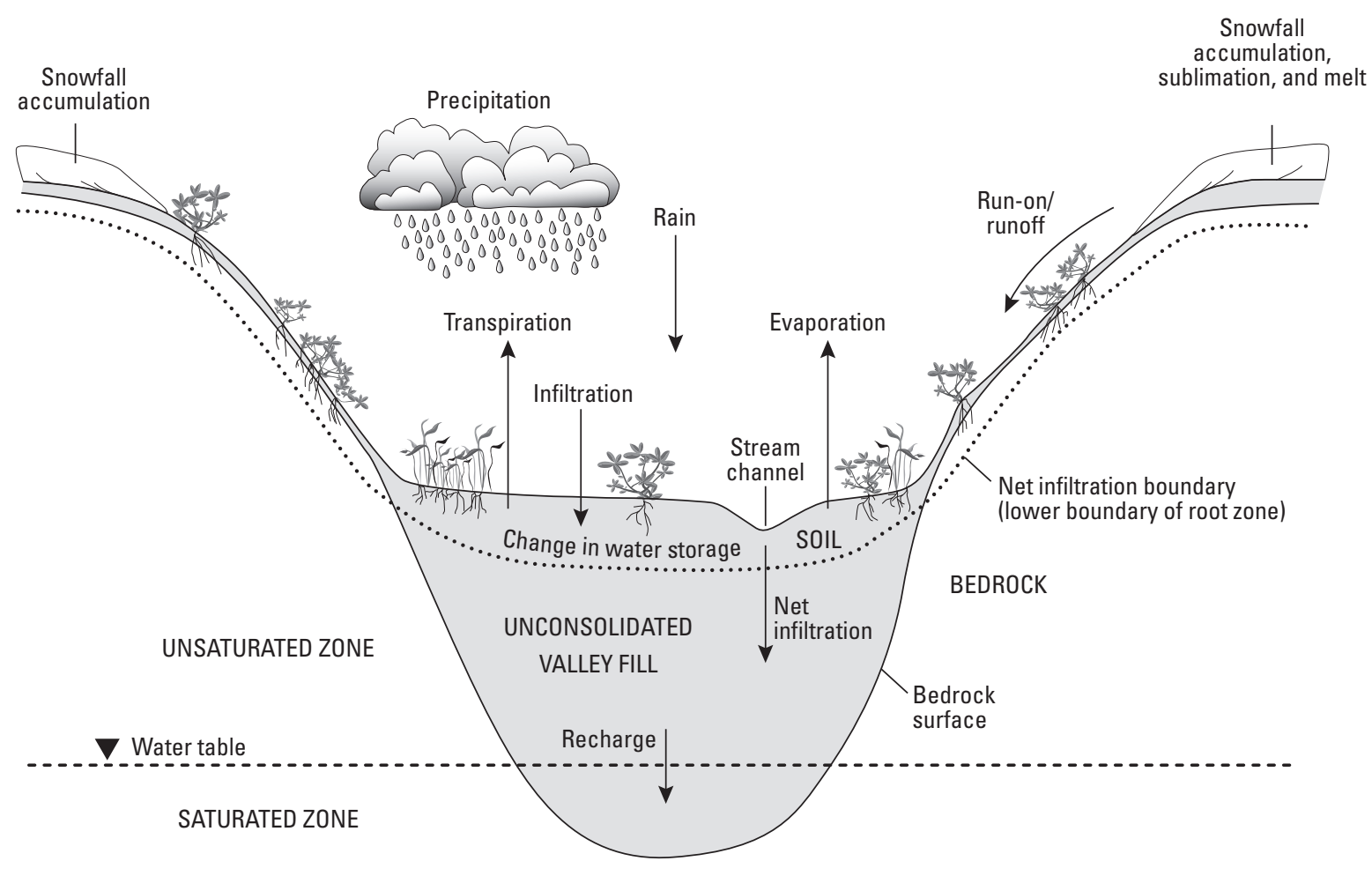

Scientific Investigations Report 2008-5006 
Cover. Schematic illustration showing some of the water-balance processes controlling net infiltration as simulated in the INFIL3.0 model. 


\section{Documentation of Computer Program INFIL3.0-A Distributed-Parameter Watershed Model to Estimate Net Infiltration Below the Root Zone}

Scientific Investigations Report 2008-5006 


\title{
U.S. Department of the Interior DIRK KEMPTHORNE, Secretary
}

\author{
U.S. Geological Survey \\ Mark D. Myers, Director
}

U.S. Geological Survey, Reston, Virginia: 2008

For more information on the USGS - the Federal source for science about the Earth, its natural and living resources, natural hazards, and the environment:

World Wide Web: http://www.usgs.gov

Telephone: 1-888-ASK-USGS

Any use of trade, product, or firm names is for descriptive purposes only and does not imply endorsement by the U.S. Government.

Although this report is in the public domain, permission must be secured from the individual copyright owners to reproduce any copyrighted materials contained within this report.

Suggested citation:

U.S. Geological Survey, 2008, Documentation of computer program INFIL3.0—A distributed-parameter watershed model to estimate net infiltration below the root zone: U.S. Geological Survey Scientific Investigations Report 2008-5006, 98 p. ONLINE ONLY 


\section{Preface}

This report describes the computer program INFIL3.0, which is a grid-based, distributedparameter, deterministic water-balance watershed model that calculates the temporal and spatial distribution of daily net infiltration of water across the lower boundary of the root zone. The bottom of the root zone is the estimated maximum depth below ground surface affected by evapotranspiration. In many field applications, net infiltration can be assumed to equal net recharge to an underlying water-table aquifer.

Earlier versions of the INFIL code were developed by the U.S. Geological Survey in cooperation with the Department of Energy to estimate net infiltration and ground-water recharge at the proposed Yucca Mountain high-level nuclear-waste repository site in Nevada. The version of the code described in this report (INFIL3.0) is a modification of these earlier versions. This version of the code was modified and tested by U.S. Geological Survey staff in the Office of Ground Water.

The code can be obtained using the Internet at address http://water.usgs.gov/software/ground_ water.html. Instructions for running the program can be found at the same Internet address.

The performance of the program has been tested in a variety of applications. Future applications, however, might reveal errors that were not detected in the test simulations. Users are requested to send notification of any errors found in this report or the model program to:

Office of Ground Water

U.S. Geological Survey

411 National Center

Reston, VA 20192

(703) 648-5001

Updates might be made to both the report and to the model program. Users can check for updates at the Internet address above. 



\section{Contents}

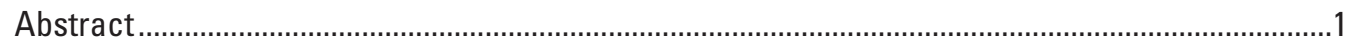

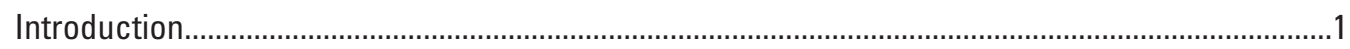

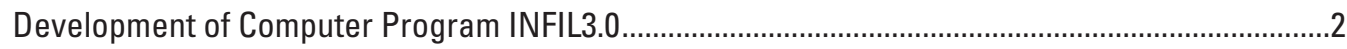

Conceptual Model of Net Infiltration ....................................................................................

Simulation of Net Infiltration ..............................................................................................

Net-Infiltration Water-Balance Model and Overview of INFIL3.0 Program......................6

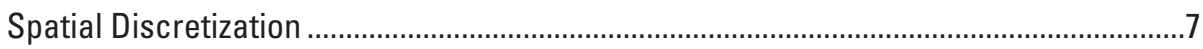

Horizontal Discretization .............................................................................

Vertical Discretization .........................................................................................

Time Steps and Initial Conditions ...................................................................................

Downstream Ordering of Grid Cells .......................................................................... 10

Surface-Water Inflows from Upstream Tributary Subbasins ...........................................10

Spatial Distribution of Daily Climate Data (Subroutine DAYDIST) .....................................11

Potential Evapotranspiration (Subroutine POTEVAP) ...................................................13

Snowfall, Snow Accumulation, Snowmelt, and Sublimation (Subroutine SNOW) .........15

Infiltration, Drainage, Evapotranspiration, and Runoff (Subroutine ETINFIL)..................16

(1) Infiltration and Initial Calculation of Runoff ...................................................16

(2) Drainage and Redistribution in the Root Zone and Initial Calculation of Change in Soil-Water Storage ......................................................................17

(3) Evapotranspiration from Each Layer of the Root Zone .....................................17

(4) Final Calculations of Net Infiltration, Change in Water Storage in Each Layer of the Root Zone, and Runoff from the Grid Cell ......................19

Surface-Water Routing (Subroutine SWINFIL) ...........................................................19

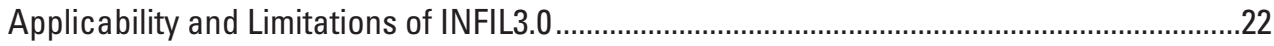

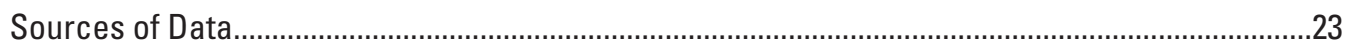

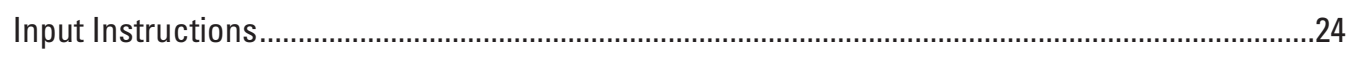

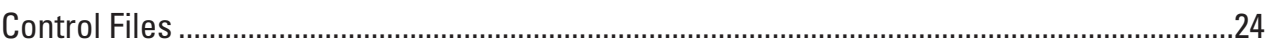

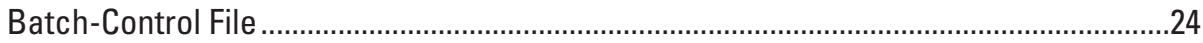

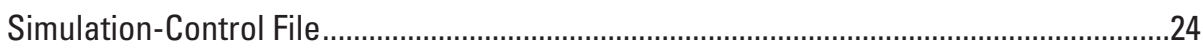

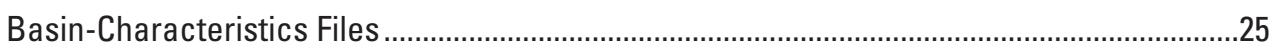

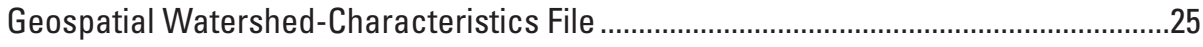

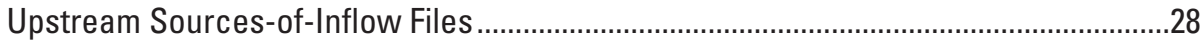

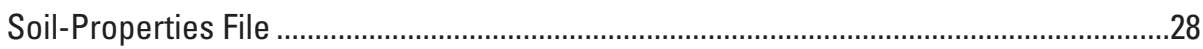

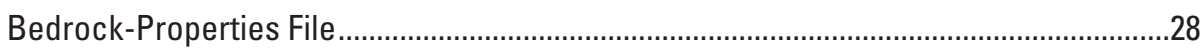

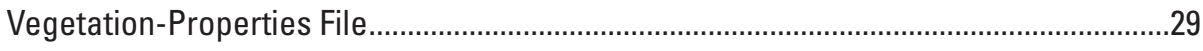

Water-Budget Components for a Simulation Restart (Restart File) ................................29

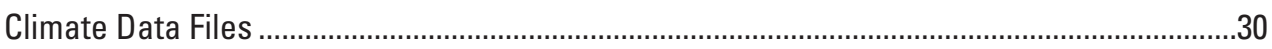

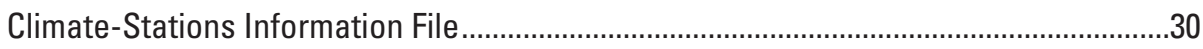

Monthly Climate-Regression Models File......................................................................30

Monthly Atmospheric-Parameters File .......................................................................

Daily Climate Files_Precipitation and Maximum and Minimum Air Temperatures ......31

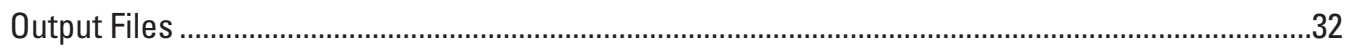

Summary Output File ...................................................................................................... 
Grid-Cell Properties Output File .............................................................................................

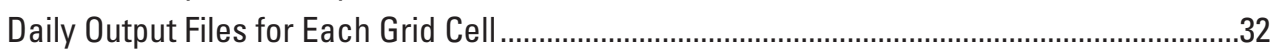

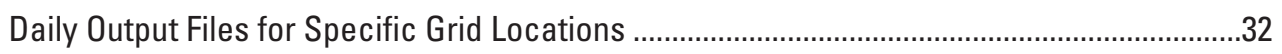

Annual and Average Annual Output Files for All Grid Cells.....................................................32

Daily and Cumulative Output File for All Grid Cells for the Last Successful Day of a Simulation (Crash File) .................................................................................................33

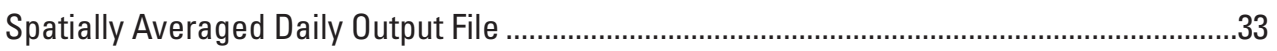

Monthly and Annual Output Files for All Grid Cells .................................................................33

Average Annual Output File for All Grid Cells for a Specified Averaging Period .....................33

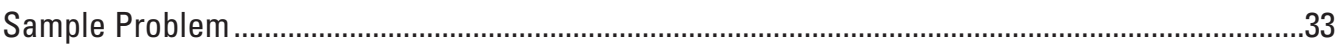



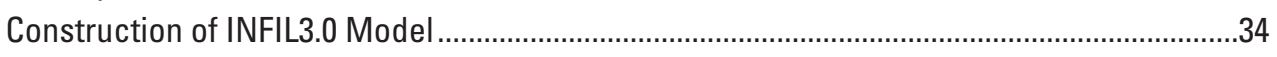

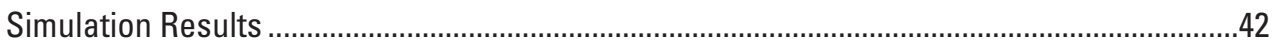

Summary.

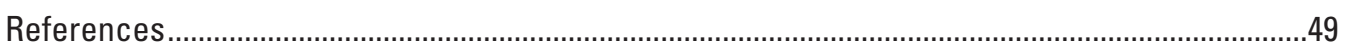



Appendix 2. Programmers' Documentation ..........................................................................65

\section{Figures}

1-2. Schematic illustrations showing-

1. Some of the water-balance processes controlling net infiltration as

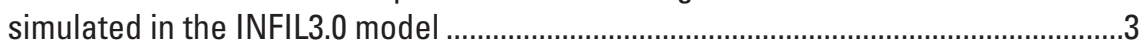

2. Vertical discretization of the root zone as a series of model layers ..........................4

3. Flowchart of the primary components of the INFIL3.0 model algorithm for simulating net infiltration

4-5. Schematic illustrations showing-

4. Horizontal discretization of a regional basin with five subbasins. . .8

5. Two upstream tributary subbasins ( 2 and 3 ) that drain into simulated subbasin 1

6-15. Input and output files showing-

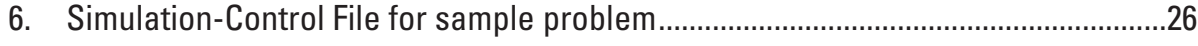

7. Climate-Stations Information File for sample problem............................................36

8. Part of Daily Precipitation File for sample problem ……………...............................37

9. Monthly Atmospheric-Parameters File for sample problem .....................................37

10. Monthly Climate-Regression Models File for sample problem.................................38

11. Geospatial Watershed-Characteristics File for sample problem .............................38

12. Soil-Properties File for sample problem .............................................................40

13. Bedrock-Properties File for sample problem .....................................................41

14. Vegetation-Properties File for sample problem ......................................................

15. Summary Output File for sample problem ............................................................4

16. Graphs showing selected model-calculated daily water-budget terms for a model cell in the sample-problem simulation: $(A)$ rain and snowmelt, $(B)$ actual evapotranspiration from the soil zone and change in water content within the soil zone, and $(C)$ net infiltration.

17. Map showing model-calculated net infiltration for sample-problem simulation ............48 


\section{Table}

1. Names of input and output files for the sample problem.

\section{Conversion Factors and Datum}

\begin{tabular}{|c|c|c|}
\hline Multiply & By & To obtain \\
\hline \multicolumn{3}{|c|}{ Length } \\
\hline centimeter $(\mathrm{cm})$ & 0.3937 & inch (in.) \\
\hline millimeter $(\mathrm{mm})$ & 0.03937 & inch (in.) \\
\hline meter $(\mathrm{m})$ & 3.281 & foot $(\mathrm{ft})$ \\
\hline kilometer $(\mathrm{km})$ & 0.6214 & mile (mi) \\
\hline \multicolumn{3}{|c|}{ Area } \\
\hline square meter $\left(\mathrm{m}^{2}\right)$ & 10.76 & square foot $\left(\mathrm{ft}^{2}\right)$ \\
\hline square kilometer $\left(\mathrm{km}^{2}\right)$ & 0.3861 & square mile $\left(\mathrm{mi}^{2}\right)$ \\
\hline \multicolumn{3}{|c|}{ Volume } \\
\hline cubic meter $\left(\mathrm{m}^{3}\right)$ & 0.0002642 & million gallons (Mgal) \\
\hline cubic meter $\left(\mathrm{m}^{3}\right)$ & 35.31 & cubic foot $\left(\mathrm{ft}^{3}\right)$ \\
\hline \multicolumn{3}{|c|}{ Flow rate } \\
\hline meter per second $(\mathrm{m} / \mathrm{s})$ & 3.281 & foot per second $(\mathrm{ft} / \mathrm{s})$ \\
\hline meter per day $(\mathrm{m} / \mathrm{d})$ & 3.281 & foot per day (ft/d) \\
\hline meter per year $(\mathrm{m} / \mathrm{yr})$ & 3.281 & foot per year $(\mathrm{ft} / \mathrm{yr})$ \\
\hline cubic meter per second $\left(\mathrm{m}^{3} / \mathrm{s}\right)$ & 35.31 & cubic foot per second $\left(\mathrm{ft}^{3} / \mathrm{s}\right)$ \\
\hline cubic meter per day $\left(\mathrm{m}^{3} / \mathrm{d}\right)$ & 35.31 & cubic foot per day $\left(\mathrm{ft}^{3} / \mathrm{d}\right)$ \\
\hline cubic meter per second $\left(\mathrm{m}^{3} / \mathrm{s}\right)$ & 22.83 & million gallons per day (Mgal/d) \\
\hline millimeters per day (mm/d) & 0.03937 & inch per day (in/d) \\
\hline millimeter per year $(\mathrm{mm} / \mathrm{yr})$ & 0.03937 & inch per year (in/yr) \\
\hline \multicolumn{3}{|c|}{ Pressure } \\
\hline kilopascal (kPa) & 0.009869 & atmosphere, standard (atm) \\
\hline kilopascal (kPa) & 0.01 & bar \\
\hline kilopascal $(\mathrm{kPa})$ & 20.88 & pound per square foot $\left(\mathrm{lb} / \mathrm{ft}^{2}\right)$ \\
\hline kilopascal (kPa) & 0.1450 & pound per square inch $\left(\mathrm{lb} / \mathrm{in}^{2}\right)$ \\
\hline \multicolumn{3}{|c|}{ Density } \\
\hline kilogram per cubic meter $\left(\mathrm{kg} / \mathrm{m}^{3}\right)$ & 0.06242 & pound per cubic foot $\left(\mathrm{lb} / \mathrm{ft}^{3}\right)$ \\
\hline \multicolumn{3}{|c|}{ Energy } \\
\hline joule $(\mathrm{J})$ & 0.0000002 & kilowatthour (kWh) \\
\hline \multicolumn{3}{|c|}{ Gravitational acceleration } \\
\hline meter per square second $\left(\mathrm{m} / \mathrm{s}^{2}\right)$ & 3.281 & foot per square second $\left(\mathrm{ft} / \mathrm{s}^{2}\right)$ \\
\hline
\end{tabular}


Temperature in degrees Celsius $\left({ }^{\circ} \mathrm{C}\right)$ may be converted to degrees Fahrenheit $\left({ }^{\circ} \mathrm{F}\right)$ as follows:

$$
{ }^{\circ} \mathrm{F}=\left(1.8 \times{ }^{\circ} \mathrm{C}\right)+32
$$

Temperature in degrees Fahrenheit $\left({ }^{\circ} \mathrm{F}\right)$ may be converted to degrees Celsius $\left({ }^{\circ} \mathrm{C}\right)$ as follows:

$$
{ }^{\circ} \mathrm{C}=\left({ }^{\circ} \mathrm{F}-32\right) / 1.8
$$

Temperature in degrees Celsius $\left({ }^{\circ} \mathrm{C}\right)$ may be converted to degrees Kelvin $\left({ }^{\circ} \mathrm{K}\right)$ as follows:

$$
{ }^{\circ} \mathrm{K}={ }^{\circ} \mathrm{C}+273.15
$$

Vertical coordinate information is referenced to the North American Vertical Datum of 1988 (NAVD 88).

Horizontal coordinate information is referenced to the North American Datum of 1983 (NAD 83).

Elevation, as used in this report, refers to distance above the vertical datum.

The latent heat of vaporization of water is measured in megajoules per kilogram $(\mathrm{MJ} / \mathrm{kg})$, which can be converted to megacalories per pound by multiplying $\mathrm{MJ} / \mathrm{kg}$ by 0.1083 . Energy units are reported in megajoules per square meter per day $\left(\mathrm{MJ} / \mathrm{m}^{2} / \mathrm{d}\right)$, which can be converted to megacalories per square foot per day by multiplying $\mathrm{MJ} / \mathrm{m}^{2} / \mathrm{d}$ by 0.0222 . 


\section{Documentation of Computer Program INFIL3.0- A Distributed-Parameter Watershed Model to Estimate Net Infiltration Below the Root Zone}

\section{Abstract}

This report documents the computer program INFIL3.0, which is a grid-based, distributed-parameter, deterministic water-balance watershed model that calculates the temporal and spatial distribution of daily net infiltration of water across the lower boundary of the root zone. The bottom of the root zone is the estimated maximum depth below ground surface affected by evapotranspiration. In many field applications, net infiltration below the bottom of the root zone can be assumed to equal net recharge to an underlying water-table aquifer. The daily water balance simulated by INFIL3.0 includes precipitation as either rain or snow; snowfall accumulation, sublimation, and snowmelt; infiltration into the root zone; evapotranspiration from the root zone; drainage and watercontent redistribution within the root-zone profile; surfacewater runoff from, and run-on to, adjacent grid cells; and net infiltration across the bottom of the root zone.

The water-balance model uses daily climate records of precipitation and air temperature and a spatially distributed representation of drainage-basin characteristics defined by topography, geology, soils, and vegetation to simulate daily net infiltration at all locations, including stream channels with intermittent streamflow in response to runoff from rain and snowmelt. The model does not simulate streamflow originating as ground-water discharge. Drainage-basin characteristics are represented in the model by a set of spatially distributed input variables uniquely assigned to each grid cell of a model grid.

The report provides a description of the conceptual model of net infiltration on which the INFIL3.0 computer code is based and a detailed discussion of the methods by which INFIL3.0 simulates the net-infiltration process. The report also includes instructions for preparing input files necessary for an INFIL3.0 simulation, a description of the output files that are created as part of an INFIL3.0 simulation, and a sample problem that illustrates application of the code to a field setting. Brief descriptions of the main program routine and of each of the modules and subroutines of the INFIL3.0 code, as well as definitions of the variables used in each subroutine, are provided in an appendix.

\section{Introduction}

The estimation of net infiltration of water below the root zone is important for quantifying the potential recharge to an underlying water-table aquifer. Although many methods are available to estimate net infiltration and (or) ground-water recharge, one of the most technically advanced is watershed modeling, which allows for the determination of temporally distributed net infiltration and recharge at locations distributed throughout a watershed. One such watershed model is the INFIL computer code. INFIL is a grid-based, distributedparameter, deterministic precipitation-runoff and netinfiltration water-balance simulation model. Net infiltration is defined as the downward drainage of water across the lower boundary of the root zone, in which the bottom of the root zone is the estimated maximum depth below ground surface affected by evapotranspiration. Net infiltration consists of three possible water sources-rain, snowmelt, and surfacewater run-on (runoff and streamflow) to each grid cell within the simulation domain.

INFIL uses a daily simulation time step to estimate the water balance, an hourly simulation time step to estimate the solar-radiation energy balance used to define potential evapotranspiration, and a multilayered root zone for simulating the processes of net infiltration and actual evapotranspiration from the root zone. The primary climatic inputs to the model are daily precipitation and maximum and minimum air temperature. These data from one or more climatic stations represent climate within the simulation domain, even if the stations are not located within the simulation domain. The INFIL model provides a detailed representation of spatially distributed drainage-basin characteristics such as vegetation, soil, and bedrock types; topographic variables such as landsurface elevation, slope, and aspect; and hydrologic processes including calculation of potential evapotranspiration, actual soil-zone evapotranspiration, and snowfall accumulation, sublimation, and snowmelt. Simulation results include a continuous time series of the daily water balance for the root zone (and for the individual root-zone layers). The daily time-series output includes simulated runoff (streamflow for channel locations), which can be compared to measured streamflow for model calibration. A primary benefit of the 
INFIL modeling approach is the generation of spatially detailed daily, annual, and average annual values representing all components of the water-balance model; these simulated results help to provide an understanding of the mechanisms responsible for net infiltration, runoff, and potential recharge. Model results can be mapped and subsequently used to evaluate the integrated effect of spatially distributed climate, terrain, and watershed characteristics (for example, vegetation, soils, and geology) on the spatial distribution of runoff and potential recharge.

INFIL was initially developed for application to the Yucca Mountain area of Nevada (Flint and others, 2001) and was subsequently extended for application to the larger Death Valley region of Nevada and California within which Yucca Mountain is located (Hevesi and others, 2002; 2003). The model also has been applied to estimate recharge for the area near Joshua Tree, California, by Nishikawa and others (2004), the San Gorgonio Pass area, Riverside County, California, by Rewis and others (2006), and the Big Bear Lake area, California (L.E. Flint, U.S. Geological Survey, written commun., April 2007).

The purpose of this report is to document a new version of the INFIL code, which is called INFIL3.0. The report describes the conceptual model of net infiltration on which the computer code is based and discusses the methods by which INFIL3.0 simulates the net-infiltration process. The report includes instructions for preparing the input files for an INFIL3.0 simulation, a description of the output files that are created as part of an INFIL3.0 simulation, and a sample problem that illustrates application of the code to a field setting. Brief descriptions of the main program routine and of each of the modules and subroutines of the INFIL3.0 code, as well as definitions of the variables used in each subroutine, are provided in appendix 2 .

\section{Development of Computer Program INFIL3.0}

\section{Conceptual Model of Net Infiltration}

The INFIL3.0 model is based on a conceptual model of the physical processes that control net infiltration. The conceptual model was developed to represent the major components of the water balance for arid to semiarid environments, but may be applicable to more humid regions as well. The components of the water balance considered in the conceptual model include precipitation; snowfall accumulation, sublimation, and snowmelt; infiltration of rain, snowmelt, and surface-water run-on into soil or bedrock; runoff; surface-water run-on; bare-soil evaporation; transpiration from the root zone; redistribution, or changes in water content, in the root zone; and net infiltration across the lower boundary of the root zone. Many of these water-balance components are illustrated in figure 1 . The conceptual model defines net infiltration as downward drainage, or flux, across the lower boundary of the root zone, or the depth at which the seasonal effects of evapotranspiration become insignificant. The conceptual model provides a framework for applying a water-balance modeling approach to develop a numerical netinfiltration model that uses a horizontal grid of model nodes (cells) and a vertical discretization representing the root zone as a series of layers having variable thicknesses (fig. 2).

The conceptual model defines rain, snowmelt, and surface-water run-on as inputs to a layered root-zone waterbalance model with one to five soil layers and a lower bedrock layer (fig. 2). Rain, snowmelt, or surface-water run-on infiltrates the soil or bedrock across the air-soil or air-bedrock interface, and then drains downward through the root zone. For each model cell, the number and thickness of layers is dependent on soil thickness, with the thickness of the lower bedrock layer increasing with decreasing soil thickness. The layers define storage components for the root zone, where root density decreases from the top to the bottom layer, and where the processes of evapotranspiration and downward drainage are dependent on the quantity of water stored in each layer and variables estimated on the basis of the vegetation, soil, and geology at each grid-cell location.

Evapotranspiration is dependent on both the water content of the root zone and potential evapotranspiration, and is separated into a bare-soil evaporation component and a transpiration component. The transpiration component is dependent on estimated root densities for each root-zone layer. Downward drainage is constrained by the saturated vertical hydraulic conductivity of the layers, the relative saturation of the layers, and the available storage capacity of the underlying layer. When the input of water to the root zone exceeds the available storage or conductance capacity of the surface layer, runoff is generated as an output component of the root-zone water balance. Runoff is routed to downstream grid cells as surface-water run-on.

During the surface-water routing process, run-on may infiltrate back into the root zone, depending on the vertical hydraulic conductivity and available storage capacity of the top layer; thus, run-on becomes an input component to the root-zone water balance. In the conceptual model, all runoff originates as excess rain, snowmelt, or surface-water run-on, and all run-on to downslope grid cells originates as runoff. Streamflow is modeled as runoff that is routed downstream from the side slopes and interchannel areas and concentrated into the channels defined by the topography. Streamflow originating as discharge from springs or as streambank seepage along gaining streams is not included in the conceptual model of net infiltration.

Redistribution of water in the root zone occurs through the combined effects of downward drainage through soil or rock and evapotranspiration after water has stopped infiltrating at the ground surface. In the conceptual model, redistribution owing to lateral flow in the root zone is assumed to be 


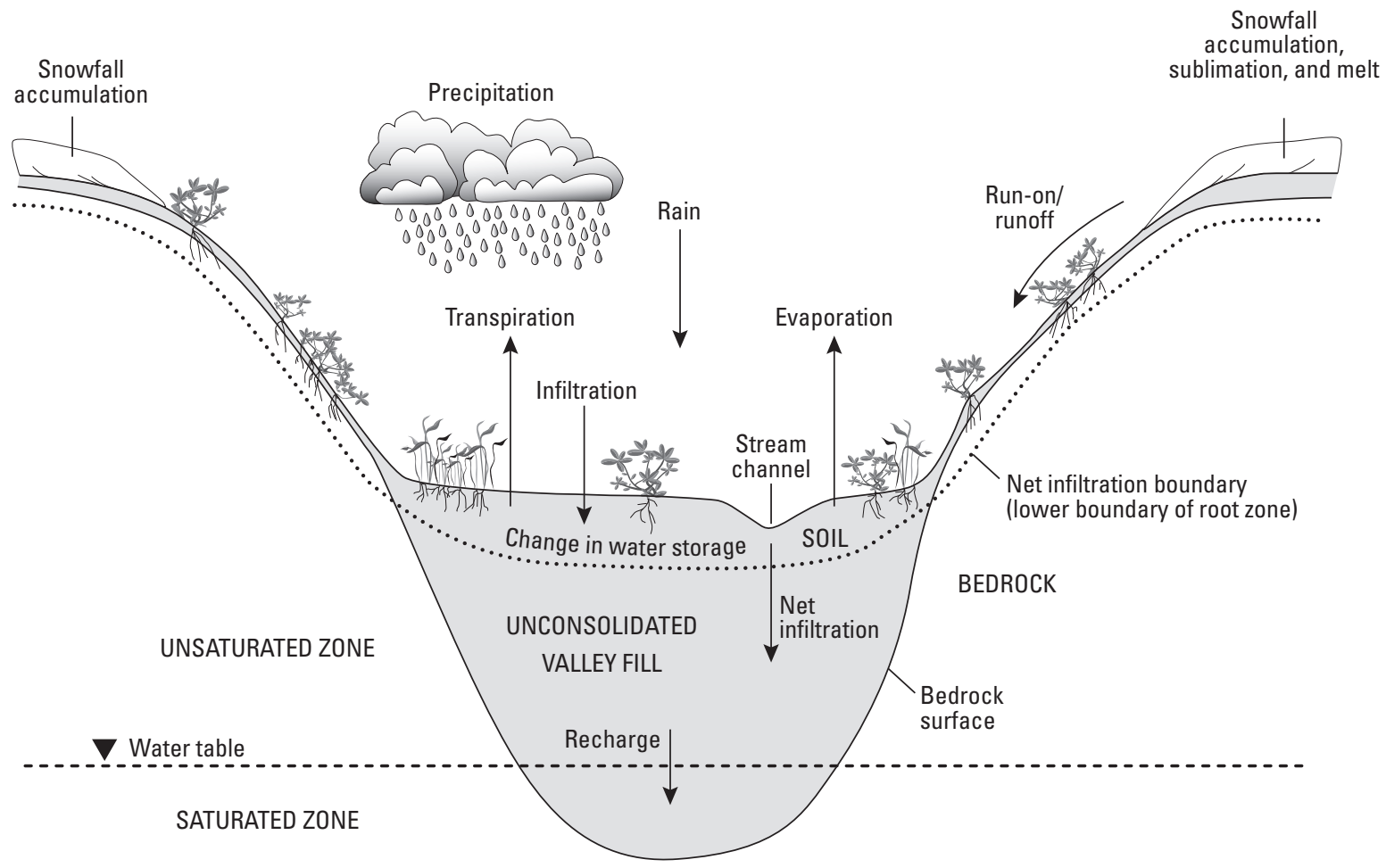

Figure 1. Some of the water-balance processes controlling net infiltration as simulated in the INFIL3.0 model.

negligible. Downward drainage through the root-zone layers can eventually result in drainage through the bottom layer (either bedrock or soil); drainage through the bottom layer is the net-infiltration output component from the root-zone water balance. Net infiltration is the drainage flux, or flow rate, at the shallowest depth beneath the ground surface where evapotranspiration no longer affects the downward drainage of infiltrated water (Flint and others 2001; Hevesi and others, 2002). In the conceptual model, the approximate depth of net infiltration is variable in both space and time. The INFIL3.0 model, however, is based on the assumption that the temporal variability in the depth of net infiltration is insignificant relative to the spatial variability in the depth of net infiltration as defined by the variable thickness of the root zone.

\section{Simulation of Net Infiltration}

The conceptual model of net infiltration forms the basis for development of a daily water-balance model that simulates the processes that affect net infiltration of water across the lower boundary of the root zone. The lower boundary of the root zone is taken to be the maximum depth below ground surface at which plant roots can extract water and soil water can be evaporated - that is, the maximum depth affected by evapotranspiration. In the remainder of the report, the term "net infiltration" is used to refer to the movement of water across the lower boundary of the root zone.

This section describes the several components of INFIL3.0. A flowchart showing the major components of the INFIL3.0 code is provided in figure 3 . In the discussion that follows, variables used in mathematical equations are written in upper- and lower-case plain italics (such as $N I_{d}^{i}$, which is the net infiltration for day $d$ and grid location $i$, in millimeters), whereas variables used in the computer program are written in lower-case plain bold text (such as celsize, which is the length of each side of each model grid cell, in meters). Also, references are made to several input files that are required for an INFIL3.0 simulation. Each of these files is described in detail in the "Input Instructions" section of the report, and sample files are provided for many of the input files in the "Sample Problem" section of the report. 


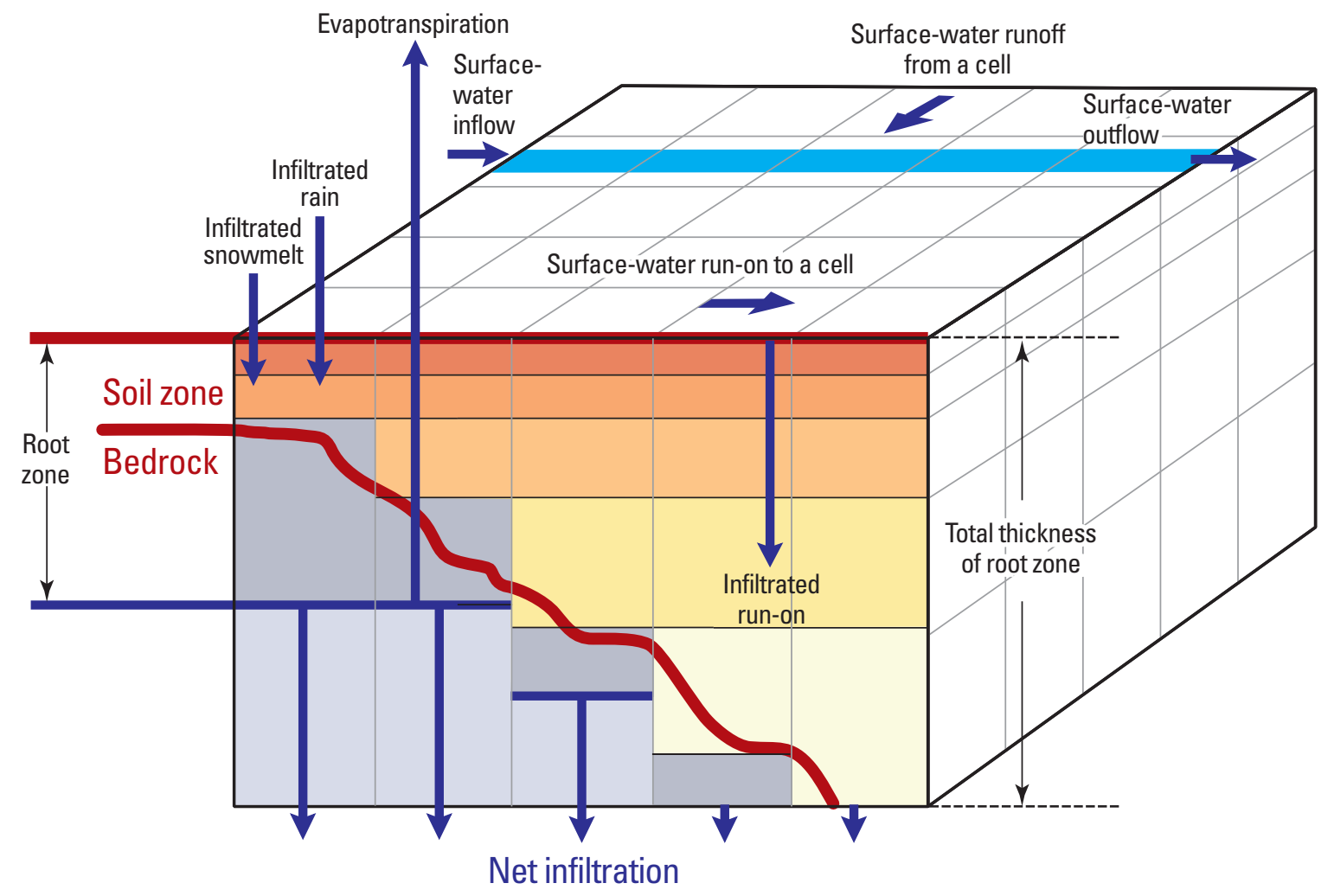

EXPLANATION

Simulated layer

Soil layer 1

$\square$ Soil layer 2

Soil layer 3

Soil layer 4

Soil layer 5

Bedrock layer (model layer 6)

Unsimulated area below root zone

Figure 2. Vertical discretization of the root zone as a series of model layers. 

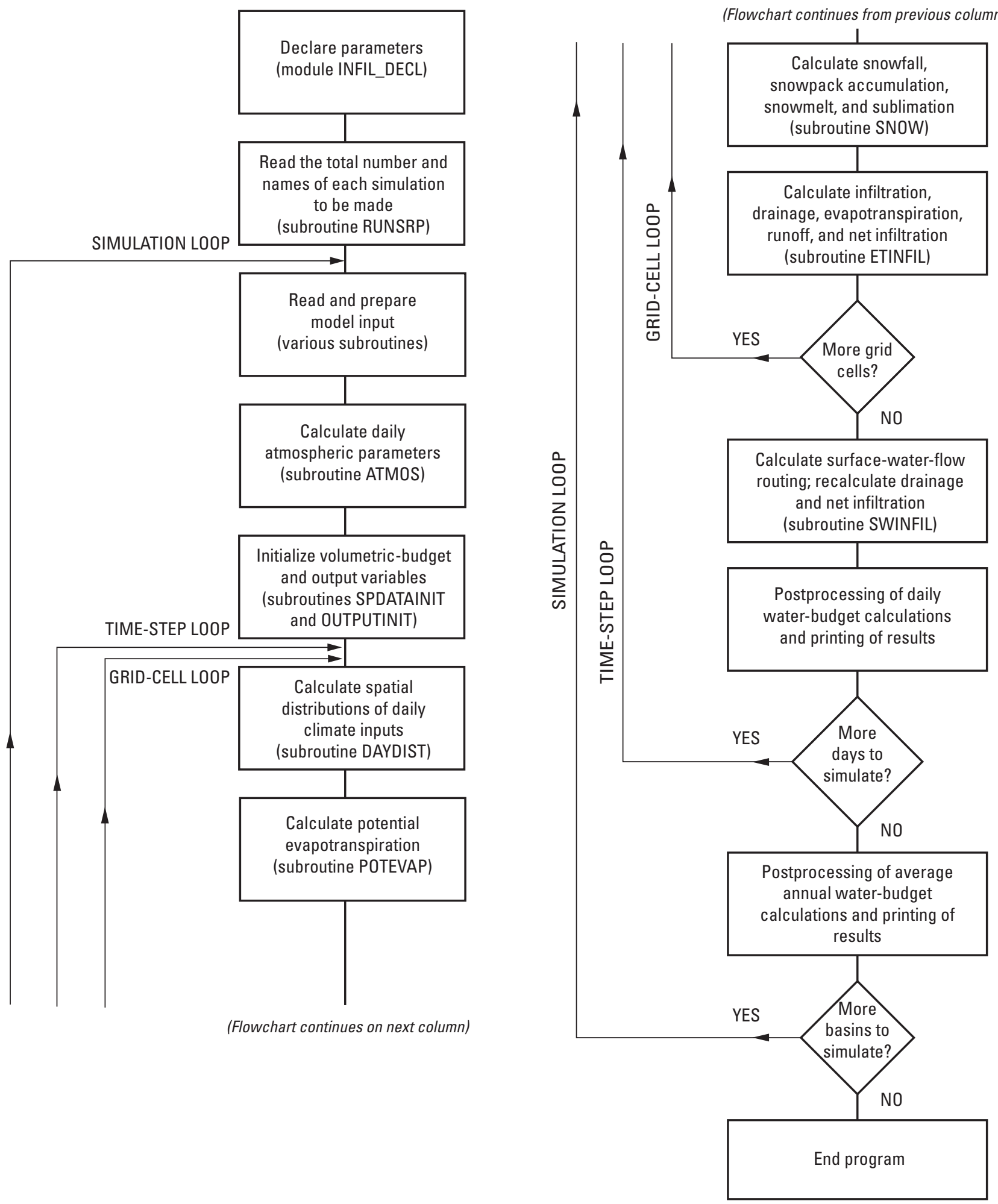

Figure 3. Flowchart of the primary components of the INFIL3.0 model algorithm for simulating net infiltration. (Code subroutines and modules associated with each component are shown in parentheses.) 


\section{Net-Infiltration Water-Balance Model and Overview of INFIL3.0 Program}

The daily root-zone water-balance simulation model is based on the governing equation

$$
\begin{aligned}
& N I_{d}^{i}=\operatorname{RAIN}_{d}^{i}+M E L T_{d}^{i}+\operatorname{Ron}_{d}^{i}-\operatorname{Roff}_{d}^{i} \\
& -\sum_{j=1}^{6}\left(\Delta W_{d}^{i}\right)_{j}-E T_{d}^{i},
\end{aligned}
$$

where

$$
\begin{aligned}
& N I_{d}^{i} \quad \text { is the net infiltration for day } d \text { and grid } \\
& \text { location } i \text {, in millimeters; } \\
& R A I N_{d}^{i} \quad \text { is precipitation occurring as rain for day } d \text { and } \\
& \text { grid location } i \text {, in millimeters; } \\
& M E L T_{d}^{i} \quad \text { is snowmelt for day } d \text { and grid location } i, \\
& \text { in millimeters; } \\
& \operatorname{Ron}_{d}^{i} \quad \text { is infiltration to the root zone due to surface- } \\
& \text { water run-on for day } d \text { to grid location } i \text {, } \\
& \text { in millimeters; } \\
& \operatorname{Roff}_{d}^{i} \quad \text { is surface-water runoff for day } d \text { from grid } \\
& \text { location } i \text {, in millimeters; } \\
& \sum_{j=1}^{6}\left(\Delta W_{d}^{i}\right)_{j} \quad \text { is the total change in root-zone water storage } \\
& \text { for all six model layers }(j=1-6) \text { for day } d \\
& \text { and grid location } i \text {, in millimeters; and } \\
& E T_{d}^{i} \quad \text { is the total bare-soil evaporation and root-zone } \\
& \text { transpiration for all six root-zone layers for } \\
& \text { day } d \text { and grid location } i \text {, in millimeters. }
\end{aligned}
$$

Water-balance calculations are based on water volumes under the assumption that temperature effects on water density are negligible. The water-balance calculations are done using water-equivalent depths, defined as the depth of water in millimeters over the area of each root-zone layer for each grid cell, because the model discretization uses equal-area grid cells. The simulation is done for a continuous time series of daily water-balance calculations. Secondary governing equations are used to represent other components of the daily water balance that are not directly defined by equation 1 , such as the hourly energy-balance calculation used for potential evapotranspiration. These secondary equations are described in detail in the sections that follow.

INFIL3.0 requires several types of input information, including (1) an estimate of initial root-zone water contents; (2) a daily time-series input consisting of total daily precipitation and maximum and minimum air temperatures; and (3) a set of model input variables that define drainage-basin characteristics, model coefficients for simulating evapotranspiration, drainage, and the spatial distribution of daily precipitation and air temperature, average monthly atmospheric conditions, and user-defined run-time options. For a multiyear simulation period, the components of the daily water balance calculated by the model are used to calculate total monthly and annual quantities and average annual rates.
An INFIL3.0 simulation consists of (1) a set of preprocessing steps for developing model inputs, (2) model initialization, (3) a simulation loop used for multiple simulations of a single watershed domain or for simulating a drainage network consisting of multiple watershed domains, (4) a daily waterbalance loop, and (5) postprocessing of the daily results for developing daily, monthly, annual, and average annual values for all water-balance terms. The daily water-balance loop includes subroutines that provide estimates of the components of the water balance, such as potential evapotranspiration, snowmelt, and sublimation. The potential evapotranspiration subroutine includes an hourly solar-radiation loop for calculating the net radiation-energy balance.

The primary computational subroutines are (fig. 3):

1. DAYDIST, a spatial-interpolation algorithm for estimating daily precipitation and air temperature at each grid cell;

2. POTEVAP, a potential-evapotranspiration model that uses incoming solar radiation calculated on an hourly basis;

3. SNOW, a snowfall, snow accumulation, snowmelt, and sublimation model;

4. ETINFIL, a root-zone infiltration and evapotranspiration routine; and

5. SWINFIL, a surface-water flow-routing and root-zoneinfiltration algorithm.

Total daily net infiltration, which is based on a root-zone drainage function, is the sum of net infiltration calculated by the ETINFIL and SWINFIL routines.

For each daily time step, the application of the SWINFIL routine is dependent on whether runoff is generated at any model grid location following an initial water-balance calculation for the root zone by the ETINFIL routine. For the initial calculation, infiltration into the root zone, evapotranspiration, changes in the root-zone water content, and net infiltration in direct response to rainfall and snowmelt are calculated by ETINFIL to determine runoff generation. If runoff is not generated, the simulation is continued to the next day. If runoff is generated (as excess rainfall or snowmelt), the surface-water-routing algorithm is activated (subroutine SWINFIL). Although infiltration to and drainage through the root zone is simulated during the flow-routing algorithm (subroutine SWINFIL), evapotranspiration is not calculated during the algorithm. During the routing process, surfacewater run-on may infiltrate into the root zone depending on the soil and bedrock vertical hydraulic conductivity and the available storage capacity of the root zone. The new value for root-zone water content is then used as the initial condition for the next day's water-balance calculations. Water that infiltrates into the root zone during the surface-water-routing process is subject to evapotranspiration the next day. Surface-water flow that does not infiltrate into the root zone becomes surfacewater discharge from the drainage basin (watershed) being modeled. In closed basins, surface water is routed to a single grid cell at the lowest elevation of the basin and is assumed 
to evaporate. Real-time streamflow is not simulated by the SWINFIL routine; all outflow is assumed to occur within a daily time step. For this reason, the INFIL3.0 model may not calculate accurate streamflow values for large watersheds characterized by a delayed response to runoff generated in upstream parts of the watershed.

The daily water balance is simulated as a continuous time series for multiyear periods, and an average net-infiltration rate is calculated on the basis of the daily results. Average annual water-balance calculations are made for each waterbalance term, which allows for an overall water-balance check for each grid cell and for the entire model domain. The waterbalance check for each grid cell is

$$
\begin{aligned}
& M B^{i}=R A I N^{i}+M E L T^{i}+\operatorname{Ron}^{i}-\operatorname{Roff}^{i} \\
& -\sum_{j=1}^{6}\left(\Delta W^{i}\right)_{j}-E T^{i}-N I^{i},
\end{aligned}
$$

\begin{tabular}{|c|c|}
\hline$M B^{i}$ & $\begin{array}{l}\text { the water-balance check at grid location } i \text {, } \\
\text { in millimeters; }\end{array}$ \\
\hline$R A I N^{i}$ & $\begin{array}{l}\text { is precipitation occurring as rain at grid } \\
\text { location } i \text {, in millimeters; }\end{array}$ \\
\hline$M E L T^{i}$ & is snowmelt at grid location $i$, in millimeters; \\
\hline $\operatorname{Ron}^{i}$ & $\begin{array}{l}\text { is infiltration to the root zone from } \\
\text { surface-water run-on at grid location } i \text {, } \\
\text { in millimeters; }\end{array}$ \\
\hline $\operatorname{Roff}^{i}$ & $\begin{array}{l}\text { is surface-water runoff from grid location } i \text {, } \\
\text { in millimeters; }\end{array}$ \\
\hline$\sum\left(\Delta W^{i}\right)_{j}$ & $\begin{array}{l}\text { is the total change in root-zone water storage } \\
\text { for all six model layers at grid location } i, \\
\text { in millimeters; }\end{array}$ \\
\hline$E T^{i}$ & $\begin{array}{l}\text { is the total bare-soil evaporation and root-zone } \\
\text { transpiration for all six root-zone layers at } \\
\text { grid location } i \text {, in millimeters; and }\end{array}$ \\
\hline$N I^{i}$ & $\begin{array}{l}\text { is the net infiltration at grid location } i \text {, } \\
\text { in millimeters. }\end{array}$ \\
\hline
\end{tabular}

where

The water-balance check $\left(M B^{i}\right)$ should be close to a value of 0 .

\section{Spatial Discretization}

Water-budget calculations in the INFIL3.0 model are based on a three-dimensional grid-based representation of the drainage basin being simulated (figs. 2 and 4). The horizontal and vertical discretization methods used for an INFIL3.0 grid are described below.

\section{Horizontal Discretization}

All grid cells are square and of equal size in the horizontal plane. The length of each side of each grid cell (in meters) is specified by using the variable celsize in the SimulationControl File. A grid of cells consisting of a set of rows and columns is superimposed over the basin of interest with the origin of the grid (that is, row 1, column 1) positioned in the upper right-hand corner (fig. 4). The grid then serves as the basis for generating spatially distributed drainage-basin characteristics, including soil types, soil depth, hydrogeologic unit, vegetation type, elevation, slope, aspect, terrain variables (blocking-ridge values), and flow-routing variables. Information for a maximum of 60,005 grid cells and 3,350 row or column grid indices can be specified for each simulation in the current version of INFIL3.0.

Previous authors (for example, Hevesi and others, 2003) have used digital elevation models (DEMs) of study basins as a template grid, or base grid, from which other basin-characteristic data can be derived by using standard Geographical Information Systems (GIS) applications. Elevation, slope, aspect, and flow-routing variables are calculated in GIS, which uses the DEM as input. Terrain variables used as input for simulating potential evapotranspiration include blocking-ridge variables (discussed in more detail below) and are calculated by preprocessing routines (Hevesi and others, 2003). Identifiers for vegetation type, soil type, and bedrock type can be assigned to model-grid cells from digital maps of vegetation, soils, and surface geology by standard vector-to-raster or overlay GIS techniques.

Each model cell is assigned row and column numbers, which are specified by integer variables row and col in the Geospatial Watershed-Characteristics File. The row and col identifiers are used in postprocessing routines to reconstruct the raster grids for each simulated water-balance term, and the grids are imported into GIS to develop the map images. In addition to the row and col identifiers, the spatial location of the centroid of each grid cell is specified by defining an eastwest (variable easting) and north-south (variable northing) spatial location and a latitude (variable lat) and longitude (variable lon) for each grid cell in the Geospatial WatershedCharacteristics file. In practice, the easting and northing location variables are based on standard map projections as defined in GIS. The easting and northing location variables are used for spatially interpolating the daily climate inputs across the model domain and thus must be consistent with the projections used to define the locations of the climate stations. The unit of horizontal distance is meters. The lat and lon location variables are used in the POTEVAP subroutine for simulating solar position for the day of the year and the hour of the day.

For efficiency, the preprocessing and parameterization is done by using the full extent of the base grid, which generally includes peripheral areas outside the area of interest. The base grid must extend over the entire basin or area of interest. The base grid is segmented into smaller watershed or catchment areas by using the developed flow-routing variables and standard GIS techniques for defining drainage networks (for example, Arc Hydro (Maidment, 2002)). The area of interest can be modeled using a single model domain or a series of subbasins, the only requirement being that any model domain or subbasin have a single outflow location, known as the pour 


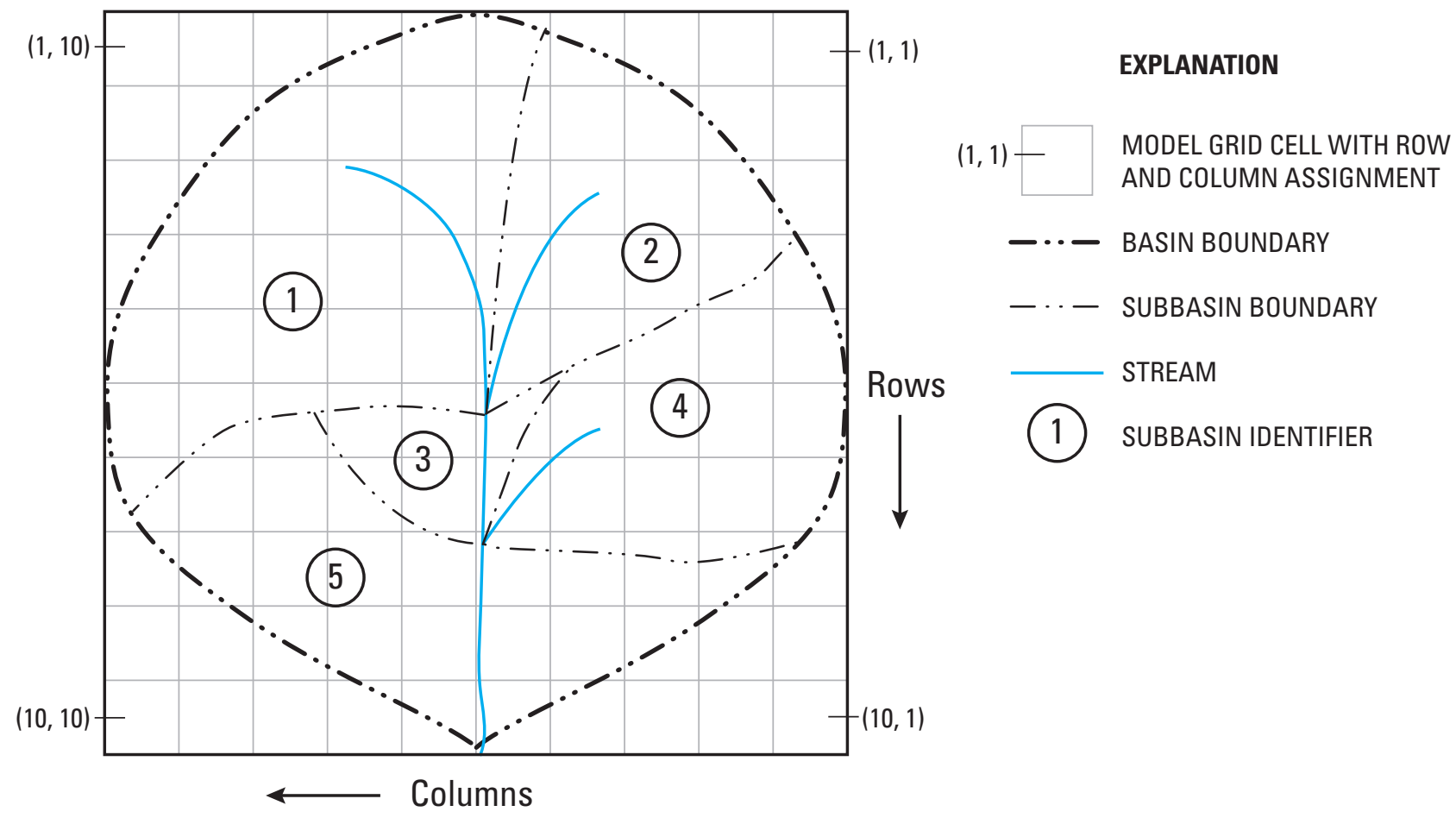

Figure 4. Horizontal discretization of a regional basin with five subbasins.

point. In the case of a closed basin or watershed, the pour point is defined as the grid cell at the lowest elevation within the basin or watershed.

The INFIL3.0 simulations are done separately for each of the individual subbasins within the larger watershed or basin area. The subbasins are defined by the modeler. Figure 4, for example, illustrates a grid of 10 rows and 10 columns that overlies the entire watershed of interest. The watershed consists of five subbasins that are simulated in five separate runs of the INFIL3.0 program. Simulations for the five separate basins are represented schematically on the INFIL3.0 flowchart (fig. 3) by the outer "Simulation Loop." Although the subbasins are simulated separately, the row and col identifiers assigned to each cell within each subbasin are referenced to the watershed-wide grid. This allows the simulation results for each subbasin to be integrated into the full extent of the base grid during postprocessing of model results.

It should be noted that the segmentation of the model domain into smaller subbasins that are simulated separately and then recombined is not a requirement for INFIL3.0. Segmentation generally improves run-time efficiency; for example, each subbasin can be simulated on separate processors, if the upstream subbasins are simulated prior to the downstream subbasins. Segmentation also can be helpful for model calibration and testing or if there is a need to identify results for separate subbasins contributing to a specific area of interest, such as a water body (L.E. Flint, U.S. Geological Survey, written commun., April 2007) or a ground-water basin (Nishikawa and others, 2004; Rewis and others, 2006).

\section{Vertical Discretization}

Vertical discretization of the root zone of each grid cell is defined by using one to five soil layers and one underlying bedrock layer; the number and thickness of soil layers and the thickness of the bedrock layer are dependent on the estimated total soil and root-zone thickness at each grid-cell location (fig. 2). The unit of vertical discretization is meters. The root zone has multiple layers to account for spatially variable estimates of the maximum depth of bare-soil evaporation and for spatial differences in root density and root-zone water content as functions of depth and variables defined by vegetation type and canopy cover. The upper five layers of the model are used to define root-zone characteristics in soil. The bottom layer (layer 6) can be used to define either (1) root-zone characteristics in consolidated bedrock where roots may extend into fractures and other openings in the bedrock or (2) a sixth soil layer for locations with thick soils. In practice, layer 6 is used only to represent bedrock, and the variables defining layer thicknesses are set such that the thickness of layer 6 is zero at locations with thick soils. However, even when the thickness of layer 6 is zero, a hydraulic conductivity value must 
be assigned to layer 6 because it will affect the calculation of net infiltration through soil layers 1 through 5 . In general, the layering can be used to represent decreases in root density with increased depth in the root zone. All six layers of the model need not be active in each cell, and the total thickness of the root zone can differ from cell to cell. Root-zone layers are deactivated when assigned a thickness of zero.

INFIL3.0 calculates the thickness of each root-zone layer for each cell on the basis of several variables specified by the user in the program input files: total soil depth for each cell (variable depth, which is specified in either the SimulationControl File or the Geospatial Watershed-Characteristics File); a soil-depth multiplication factor for the entire modeled area (variable sdfact, which is specified in the Simulation-Control File); root-zone depths for each soil layer for each vegetation type and the bedrock-layer thickness for each vegetation type (variable rzdpth, which is an array of six values that are specified in the Vegetation-Properties File); and a root-zone depth factor (variable rzdpthf, which is specified for each vegetation type in the Vegetation-Properties File). Note that the first five values of array rzdpth are depths below land surface and the sixth value is an actual thickness. Soil depths can be specified for each grid location by using the variable depth in the Geospatial Watershed-Characteristics File. For this alternative, variable isdepthval is set to a value other than 1 in the Simulation-Control File. Alternatively, the user can specify a constant soil depth for all grid cells by setting isdepthval equal to 1 and using variable sdepthval in the Simulation-Control File to specify the constant soil depth (in meters). When a constant soil depth is used, values entered for depth in the Geospatial Watershed-Characteristics File are ignored.

The first step done by INFIL3.0 to calculate root-zone layer thicknesses is to multiply the soil depth (depth) specified for each grid cell by the soil-depth factor sdfact. This multiplication factor was introduced because experience with the STATSGO database, which was the source of soil-depth values in previous studies that have used previous versions of the code, indicates that the values of soil depth reported in the STATSGO database can have considerable uncertainty, particularly when projected across mountainous watersheds. In addition, the increased soil thickness is used to account indirectly for surface-retention storage, which is not explicitly defined in INFIL3.0. Therefore, a user can use sdfact as a multiplication factor for the STATSGO-derived soil depths during the model-calibration process. For example, a user can specify an initial value of sdfact as 1.0 and then modify sdfact as necessary to improve simulation results during the modelcalibration process. The use of sdfact in model calibration preserves the relative differences in estimated soil thickness across the model domain, but allows the absolute soil thickness to vary. In addition, model sensitivity to the estimated soil thickness, which in previous applications of the code has been observed to be high, can easily be evaluated by using the sdfact multiplier because this does not require repeating any of the preprocessing steps needed for the initial development of model inputs (Rewis and others, 2006).
The second step in the root-zone layer calculations sets the maximum root-zone depth equal to the bottom of the fifth root-zone layer for those cells in which total soil depth (depth) is greater than the root-zone depth for layer 5. This step prevents the soil-zone depth, which may have been increased by the multiplication factor sdfact, from extending beneath the root zone for the vegetation type. Thus, the sdfact multiplier generally affects only those grid cells that represent thin soils.

In the next step, INFIL3.0 calculates the thickness of each of the five soil root-zone layers by first identifying which layer is the bottom soil-zone layer for the cell and then subtracting the depths between intervening root-zone depths to determine the thickness of each layer. For example, if the user specifies root-zone depths for the five layers of a particular vegetation type as $0.1,0.3,1.0,3.0$, and $8.0 \mathrm{~m}$ below land surface, respectively, and the soil depth (depth) for the grid cell of interest is $1.3 \mathrm{~m}$ (and sdfact equals 1.0), then the resulting thicknesses for the five layers will be: layer 1, $0.1 \mathrm{~m}$; layer 2, $0.2 \mathrm{~m}$; layer 3, $0.7 \mathrm{~m}$; layer 4, $0.3 \mathrm{~m}$; and layer 5, $0.0 \mathrm{~m}$.

In the last step, INFIL3.0 calculates the thickness of the bedrock root-zone layer by subtracting the ratio depth/ rzdpthf from the bedrock root-zone layer thickness specified as part of the rzdpth array. For example, if in the previous example a bedrock-layer thickness of $4.0 \mathrm{~m}$ was specified, and an rzdpthf of 1.0 was specified, then the resulting thickness for the bedrock layer (layer 6 ) would be $4.0-1.3=2.7 \mathrm{~m}$. The factor rzdpthf allows the user to vary the total rootzone-thickness soil depth (depth) in relation to the estimated soil depth (depth) for locations with thin soils (and an active bedrock layer). For example, if the user wanted to increase the total thickness of the root zone according to the estimated soil thickness, then a value for rzdpthf greater than 1.0 could be specified; this value would reduce the ratio depth/rzdpthf and increase the resulting bedrock-layer thickness as the soil thickness increased (relative to the values of these variables calculated with rzdpthf equal to 1.0). As with the variable sdfact, variable rzdpthf allows the user to adjust the thickness of the bedrock layer easily during model calibration, rather than repeat a preprocessing step.

\section{Time Steps and Initial Conditions}

INFIL3.0 uses a daily time step for water-balance calculations. The user specifies the beginning and ending dates of a simulation in the Simulation-Control file using variables yrstart, mostart, and dystart for the simulation start date and yrend, moend, dyend for the simulation end date. INFIL3.0 can read in daily climate information (precipitation and minimum and maximum air temperature) from the climate files for dates that fall outside the beginning and ending simulation dates, but those climate records will not be used in the waterbudget calculations.

Most of the water-balance terms in the INFIL3.0 model are given initial-condition values of 0 , and are then updated for each day of the simulation. Initial conditions, however, must be specified for the water contents of the five soil layers. 
Three options are provided for specifying initial soil-water contents depending on the value of variable initopt specified in the Simulation-Control File. If initopt is set to 0 , then the initial water content of each layer at each cell is set equal to the product of the porosity of the soil at the cell (which is specified in the Soil-Properties File), the thickness of the soil layer (in millimeters), and variable vwcfact, which is also specified in the Simulation-Control File. Variable vwcfact is a multiplication factor that can be used during model calibration to vary the initial water contents. If initopt is set to 1 , then the initial water content of each layer at each cell is set equal to the product of the residual water content of the soil (which is specified in the Soil-Properties File), the thickness of the soil layer (in millimeters), and variable vwcfact. If initopt is set to 3 , then the initial soil-water contents for each layer at each cell are read from the file specified by variable restartfile in the Simulation-Control File. The format of restartfile is exactly the same as that of the crashfile, whose name is also specified in the Simulation-Control File. The contents of crashfile are described in detail in the section of the report titled "Daily and Cumulative Output File for all Grid Cells for the Last Successful Day of a Simulation (Crashfile)."

Initial conditions for the bedrock water content are either set to 0 or are read from file restartfile if initopt has been set to 3. Initial conditions for the snow-pack storage term and the runoff-storage terms are also set to zero or are read from file restartfile if initopt has been set to 3 . In other words, an assumption is made that there is no snow pack or runoff at the start of the simulation. In practice, a model ramp-up or warmup period is used to minimize the effect of uncertainty in the initial conditions, which in the majority of model applications tends to be high. The ramp-up period is excluded from the simulation period used for model calibration or application. Model ramp-up periods of 2 to 3 years are generally sufficient to eliminate model sensitivity to the initial conditions.

\section{Downstream Ordering of Grid Cells}

Calculations made by the surface-water-flow routing algorithm in INFIL3.0 are based on the assumption that the grid cells have been entered in the Geospatial WatershedCharacteristics File in upstream-to-downstream order. For example, the cells might be entered in downstream order based on decreasing elevation from the top of the basin to the pour point of the basin. The correct upstream-to-downstream ordering is critical because as the model steps through each successive grid cell for each day, all runoff terms for all upstream grid cells (as calculated by ETINFIL and SWINFIL) must be known. Original applications of earlier versions of the INFIL code used FORTRAN preprocessing routines for developing the upstream-to-downstream ordering of the base grid on the basis of the DEM as input (Hevesi and others, 2003). More recent applications have used standard GIS applications such as Arc Hydro for processing the DEM, which is needed to define the upstream-to-downstream ordering of all grid cells (L.E. Flint, U.S. Geological Survey, written commun., April 2007). The upstream-to-downstream ordering is an important part of the preprocessing procedure because this ordering defines the location and connectivity of streamlines for the model domain and subsequently defines the drainage network used for developing subbasins and identifying pour points. Techniques can be used to modify the DEM to ensure that the model streamlines representing the main stream channels agree with the known hydrography of the study area. For example, digital maps of hydrographic features (streams, canals, lakes, and playas) can be incorporated in GIS applications to modify the DEM prior to defining the upstream-to-downstream ordering.

Input variables associated with the upstream-todownstream ordering are the upstream cell identifier locid and the downstream cell identifier iwat. Each grid cell can provide runoff to only one downstream cell, but each cell may have multiple cells that contribute surface-water run-on to it. A value of iwat equal to -3 is used to specify the pour-point cell location of the basin; this cell is not used in any of the waterbalance calculations.

An additional input variable, upcells, is used to specify the total number of upstream cells that contribute water to the cell. Upcells is specified in the Geospatial WatershedCharacteristics File and is used in the surface-water flowrouting algorithm. The value of upcells can include cells that occur in upstream tributary subbasins that contribute surfacewater inflow to the subbasin being simulated. Upcells is a standard output term calculated as part of the preprocessing used to define the upstream-to-downstream ordering. For example, in Arc Hydro applications, upcells is equivalent to the "flow accumulation" value calculated after the "flow direction" term is derived for each grid cell by the D-8 routing algorithm (Maidment, 2002) and prior to the calculation of streamline segments and subcatchment areas.

\section{Surface-Water Inflows from Upstream Tributary Subbasins}

INFIL3.0 allows surface-water inflows to a simulated basin from a maximum of five upstream tributary subbasins. Each upstream flow must occur to a single grid cell in the simulated basin (fig. 5). Inflows to a basin are modelcalculated streamflows from upstream subbasins that have been calculated in previous simulations. As an example, simulations are made for each of the two upstream subbasins in figure 5 (subbasins 2 and 3), and the results of these simulations, including the model-calculated streamflow leaving each subbasin, are saved as part of the pointfile(1) output file for each upstream subbasin.

Surface-water inflows are simulated when variable nupstream is set equal to a value greater than 0 in the Simulation-Control File. The user then has the option of either specifying the names of the files from which upstream flows will be read or specifying a constant daily rate of inflow 


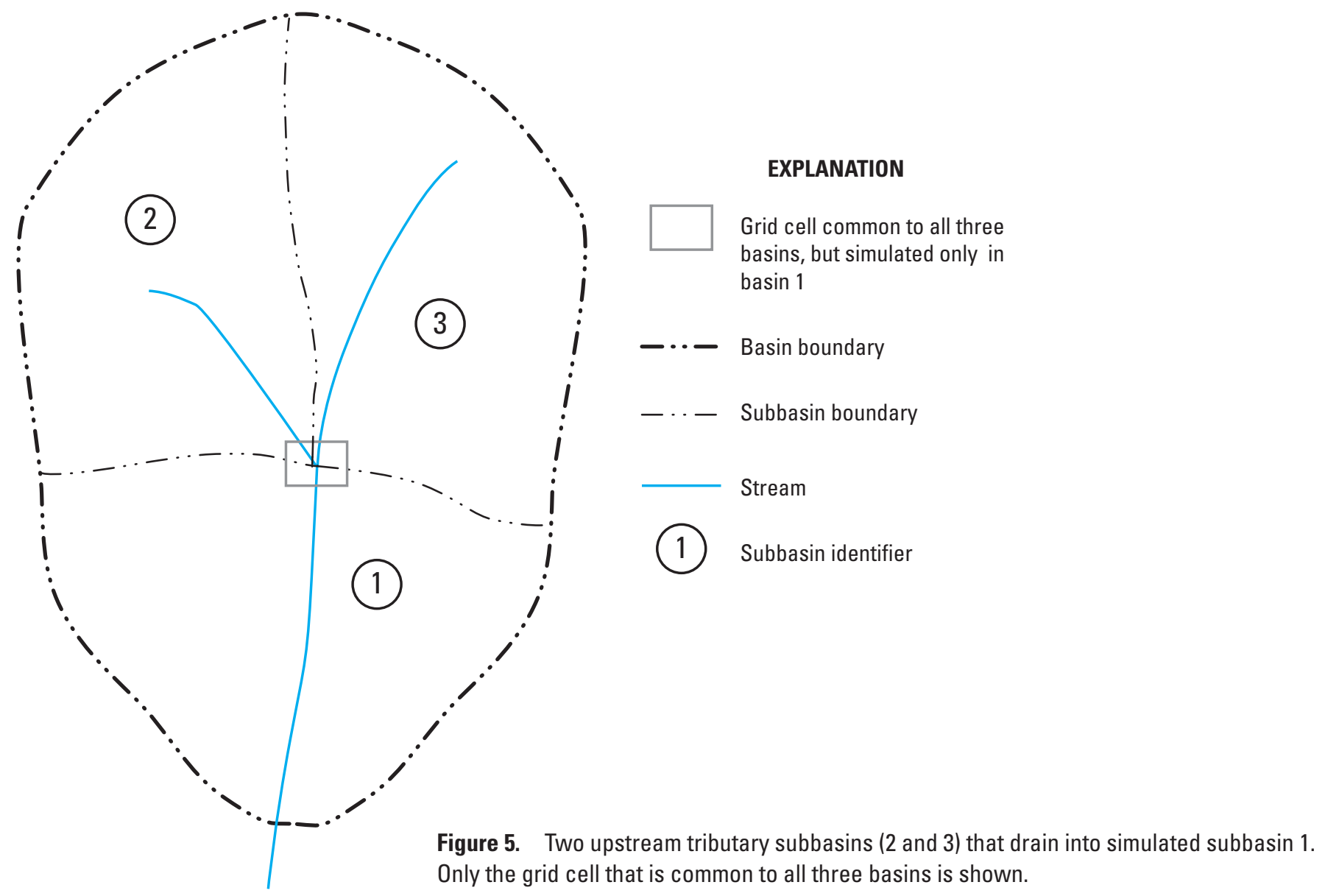

(upconst) from each upstream basin. The constant daily rate of inflow is used as a testing parameter.

Two files are actually read by INFIL3.0 for each subbasin that contributes upstream flow. First, the user must specify the name of an upgeoinp file in the Simulation-Control File for each upstream subbasin. This file has the same format as the Geospatial Watershed-Characteristics File for the upstream subbasin; therefore, the Geospatial Watershed-Characteristics File for each upstream subbasin can be specified for upgeoinp. The entire contents of this file are read by INFIL3.0; however, the only purpose of reading data from this file is to ensure that the last grid cell specified in the file (with variable iwat $=-3$ ) has a value of cellcode that is the same as the last value of cellcode in each of the upstream subbasins and is equal to the cellcode of the grid cell that receives the upstream flow in the main basin. If any of the values of cellcode differ, INFIL3.0 will stop execution.

The second file that is read for each upstream subbasin is specified using variable upfile, also in the Simulation-Control File. As mentioned above, this is the pointfile(1) output file that contains the upstream daily flow for each upstream sub- basin. Therefore, the user simply needs to specify the name of the pointfile(1) for each subbasin. The user also has the option of overwriting the upstream flows read from each upfile by using variable ioptupflow in the Simulation-Control File.

If ioptupflow is set to a value other than 0 , then a constant upstream flow equal to upconst can be used.

\section{Spatial Distribution of Daily Climate Data (Subroutine DAYDIST)}

Daily precipitation and air-temperature data are spatially distributed across the model domain by subroutine DAYDIST. INFIL3.0 provides two approaches to distribute precipitation and air-temperature data across the model domain: the first is by use of monthly precipitation/elevation and air-temperature/ elevation regression models in combination with an inversedistance-squared interpolation algorithm; the second is by use of a simpler inverse-distance-squared interpolation model. The regression models are described first, followed by the inversedistance-squared interpolation approach. 
Regression-model coefficients are developed prior to an INFIL3.0 simulation by using monthly data compiled from climate records. Regression models define average monthly precipitation and maximum and minimum air temperatures as functions of elevation. The monthly values for each climate variable (precipitation and maximum and minimum air temperatures) do not change with time; therefore, their values are calculated at the beginning of a simulation.

Two types of regression models are supported by INFIL3.0. The first is a linear model (regression-model type 1)

$$
E_{m}^{i}=A_{m}\left(E L E V^{i}\right)+B_{m}
$$

and the second is a quadratic model (regression-model type 3)

$$
E_{m}^{i}=A_{m}\left(E L E V^{i}\right)^{2}+B_{m}\left(E L E V^{i}\right)+C_{m}
$$

where

$$
\begin{array}{r}
E_{m}^{i} \quad \text { is the estimated average monthly climate } \\
\text { variable (daily precipitation, maximum air } \\
\text { temperature, or minimum air temperature) }
\end{array}
$$
for grid location $i$ and month $m$;

$A_{m}, B_{m}, C_{m}$ are the regression-model coefficients for each month $m$; and

$E L E V^{i} \quad$ is the elevation for grid location $i$ (in meters).

Regression models of the form of equations 3 and 4 also are used to estimate average monthly climate variables (precipitation and maximum and minimum air temperatures) at each of the climate stations; these estimates have the notation $E_{m}^{k}$, where the superscript $k$ indicates climate-station $k$. The monthly estimate for the grid location is obtained by using the developed monthly regression models for each climate variable and the estimated elevation of the location being interpolated, as specified by a DEM. Estimates for the climate stations are done in subroutine MMPARAMRP.

In the first step of the spatial-interpolation routine, the sum of the inverse-squared distances between the grid location and each active climate station are calculated for each parameter by the equation

$$
S D I S T_{C V}^{i}=\sum_{k=1}^{N S T} 1 /\left(d i s t^{k}\right)^{2}
$$

where

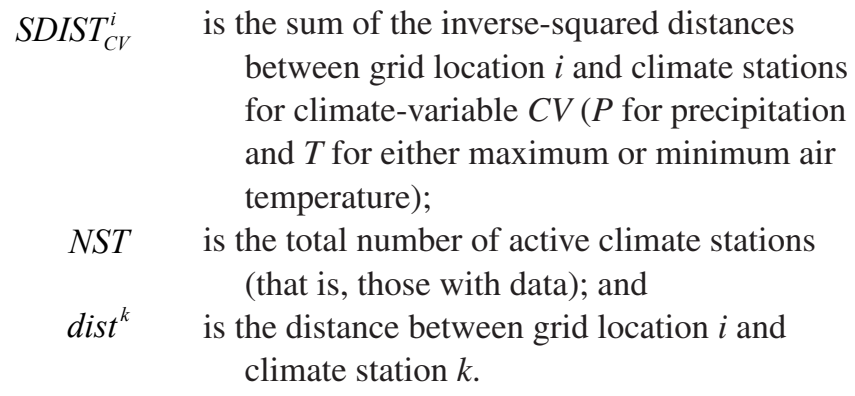

In the next step of the routine, the interpolated daily value is calculated for the grid location by means of a modified inverse-distance-squared interpolation. For precipitation, this equation is

$$
E_{d}^{i}=\sum_{k=1}^{N S T}\left\{\left[\left(1 /\left(\text { dist }^{k}\right)^{2}\right) / S D I S T_{P}^{i}\right] \frac{\left(E_{m}^{i}\right)}{\left(E_{m}^{k}\right)}\left(X_{d}^{k}\right)\right\}
$$

where

$$
\begin{array}{cl}
E_{d}^{i} & \text { is the estimated daily precipitation for grid } \\
& \text { location } i \text { and day } d ; \\
E_{m}^{i} & \text { is the estimated average monthly precipitation } \\
& \text { for grid location } i \text { and month } m ; \\
E_{m}^{k} & \text { is the estimated average monthly precipitation } \\
& \text { for climate station } k \text { and month } m \text {; and } \\
X_{d}^{k} & \text { is the daily precipitation at climate station } k \\
& \text { and day } d .
\end{array}
$$

If the estimated precipitation is less than 0.254 millimeters ( 0.01 inches), then the estimated value is set to 0 under the assumption that 0.01 inch is the lower bound on the measurable precipitation data.

For maximum and minimum air temperature (in ${ }^{\circ} \mathrm{F}$ or ${ }^{\circ} \mathrm{C}$ ), the modified inverse-distance-square interpolation equation used is

$$
E_{d}^{i}=\sum_{k=1}^{N S T}\left\{\left[\left(1 /\left(\text { dist }^{k}\right)^{2}\right) / S D I S T_{T}^{i}\right]\left[\left(E_{m}^{i}-E_{m}^{k}\right)+X_{d}^{k}\right]\right\},
$$

where

$$
\begin{gathered}
E_{d}^{i} \quad \begin{array}{l}
\text { is the estimated daily maximum or minimum } \\
\text { air temperature in }{ }^{\circ} \mathrm{F} \text { or }{ }^{\circ} \mathrm{C} \text { for grid } \\
\text { location } i \text { and day } d ;
\end{array} \\
E_{m}^{i} \quad \text { is the estimated average monthly maximum or } \\
\text { minimum air temperature for grid location } \\
\quad i \text { and month } m \text {; } \\
E_{m}^{k} \quad \text { is the estimated average monthly maximum } \\
\text { or minimum air temperature for climate } \\
\text { station } k \text { and month } m \text {; and } \\
X_{d}^{k} \quad \text { is the daily maximum or minimum air } \\
\text { temperature at climate station } k \text { and day } d .
\end{gathered}
$$

Average daily air temperature for the grid cell is calculated as the average of the estimated maximum and minimum daily air-temperature values. If there are no air-temperature data for a particular date (that is, $N S T=0$ ), then the average daily air temperature is set to an assumed value of $15^{\circ} \mathrm{C}$.

The second approach to distribute precipitation and air-temperature data across the model domain - that is, the simpler inverse-distance-squared interpolation model-also is based on equations 5 through 7 . However, in the inversedistance-squared interpolation model for precipitation, the ratio $\frac{E_{m}^{i}}{E_{m}^{k}}$ in equation 6 is replaced by a value of 1.0 ; for maximum and minimum air temperature, the term 
$\left[\left(E_{m}^{i}-E_{m}^{k}\right)+X_{d}^{k}\right]$ in equation 7 is replaced by the simpler term $\left[X_{d}^{k}\right]$.

The user can override all of the previous calculations of precipitation and (or) air temperature described in this section by using variables ipptval and iairval, which are specified in the Simulation-Control File. If these variables are set to a value of 1 , then the user can specify constant precipitation and (or) air-temperature values that are used for the simulation. These constant values of precipitation and air temperature are specified by variables pptval and airval in the SimulationControl File. Also, the user can adjust the values of precipitation calculated by the methods described previously (or using pptval) by use of the multiplication factor pptfact, which can be used during model calibration to adjust the values of precipitation. Variable pptfact is also specified in the SimulationControl File.

\section{Potential Evapotranspiration (Subroutine POTEVAP)}

Spatially distributed potential evapotranspiration is calculated in subroutine POTEVAP. A major component of the subroutine is the calculation of net incoming radiant energy $(R n)_{d}^{i}$ for each day $d$ and each grid location $i$. This calculation is done by use of a model of solar radiation similar to the SOLRAD model described in Flint and Childs (1987) and is based partly on work reported by Iqbal (1983).

Daily solar radiation is calculated by using National Weather Service monthly regional atmospheric properties, average daily temperature at each grid cell, and detailed geometric properties for each grid cell. The atmospheric properties are monthly averages of ozone, precipitable water, atmospheric turbidity, circumsolar diffuse radiation, and ground albedo. Site geometric properties include latitude, longitude, slope, aspect, elevation, and the blocking angles above a horizontal surface for direct-beam and diffuse sky radiation. The blocking angles define the effects of shading caused by the surrounding topography. For example, a location at the bottom of a steep, narrow canyon or valley will be shaded from direct-beam radiation more often than a location on the top of a south-facing hillslope. In addition, diffuse sky radiation will be reduced proportionally by the net effect of the surrounding terrain in blocking out the sky. However, ground-reflected radiation may be greater for a shaded location relative to a location on a ridgetop, depending on the orientation of the shaded location relative to solar position and the surrounding terrain. A separate FORTRAN program, SKYVIEW, which is a modified version of the original algorithm provided in Flint and Childs (1987), can be used to calculate the blocking angles (also referred to as blocking-ridge angles) above horizontal for each of 36 10-degree horizontal arcs around every grid cell (blocking-ridge angles). Calculations in SKYVIEW are made by using a DEM as input and a technique for approximating the 10-degree horizontal distances described in Flint and Childs (1987).
To calculate net incoming radiant energy, the position of the sun is calculated every hour, starting at sunrise on each day, with the site location (latitude and longitude) and the simulation day number as inputs (Flint and Childs, 1987). Direct-beam and diffuse sky radiation are calculated on the basis of the atmospheric properties and applied to the surface on the basis of slope, aspect, and the amount of sky and sun that would be blocked by the surrounding topography. Ground-reflected radiation is added on the basis of the area of the surrounding topography, the ground albedo, and the direct-beam and diffuse sky radiation that is reflected from the surrounding topography.

Net incoming radiant energy, $(R n)_{d}^{i}$, is equal to the difference between net short-wave radiation and net longwave radiation (Shuttleworth, 1993). The equations used for calculating net short-wave radiation are described in detail by Flint and Childs (1987). Net long-wave radiation is calculated from (Shuttleworth, 1993):

$$
L n=5.6697 \times 10^{-8}\left(0.98-\varepsilon_{a c}\right)\left(T A_{d}^{i}\right)^{4}(H S T E P)(3600 .)
$$

where

Ln is net long-wave radiation, in joules per square meter;

$\varepsilon_{a c} \quad$ is clear sky emissivity, dimensionless;

$T A_{d}^{i} \quad$ is the average daily air temperature on day $d$ at grid location $i$ in degrees Kelvin; and

HSTEP is the time-step length, in hours, used for calculating total daily evapotranspiration.

Variable HSTEP is specified by the user (by variable hstep) in the Simulation-Control File.

Clear-sky emissivity $\left(\varepsilon_{a c}\right)$ is calculated from equation 10.11 in Campbell and Norman (1998):

$$
\varepsilon_{a c}=9.2 \times 10^{-6}\left(T A_{d}^{i}\right)^{2}
$$

where $T A_{d}^{i}$ and $\varepsilon_{a c}$ are defined in equation 8 .

Daily evapotranspiration from each root-zone layer is calculated as an empirical function of potential evapotranspiration and soil-water content on the basis of a modified form of the Priestley-Taylor equation (Flint and Childs, 1991). The Priestley-Taylor equation (Priestley and Taylor, 1972) is used to calculate potential evapotranspiration:

$$
\lambda(P E T)_{d}^{i}=\alpha\left(\frac{S}{S+\gamma}\right)_{d}^{i}\left((R n)_{d}^{i}-G_{d}^{i}\right),
$$

where

$\lambda$ is the latent heat of vaporization of water, in megajoules per kilogram $(\mathrm{MJ} / \mathrm{kg})$;

$(P E T)_{d}^{i} \quad$ is the rate of potential evapotranspiration at grid location $i$ and day $d$, in millimeters per day; 
$\alpha \quad$ is an empirical coefficient that is often set equal to 1.26 for freely evaporating surfaces (Priestley and Taylor, 1972; Stewart and Rouse, 1977; Eichinger and others, 1996), dimensionless;

$S$

is the slope of the saturation vapor-pressure/ temperature curve, in kilopascals per degree Kelvin;

$\gamma \quad$ is the psychrometric constant, in kilopascals per degree Kelvin;

$(R n)_{d}^{i} \quad$ is net incoming radiant energy for location $i$ and day $d$, in megajoules per square meter per day $\left(\mathrm{MJ} / \mathrm{m}^{2} / \mathrm{d}\right)$; and

$G_{d}^{i} \quad$ is soil heat flux for location $i$ and day $d$, in megajoules per square meter per day $\left(\mathrm{MJ} / \mathrm{m}^{2} / \mathrm{d}\right)$.

The product $\lambda(P E T)_{d}^{i}$ is the latent heat flux (units of megajoules per square meter per day). The latent heat of vaporization $(\lambda)$ is approximated in POTEVAP by equation 4.2.1 from Shuttleworth (1993),

$$
\lambda=2.501-0.002361 T_{s}
$$

where $T_{s}$, the surface temperature of water, is assumed to be $20^{\circ} \mathrm{C}$; therefore, $\lambda$ is equal to $2.45 \mathrm{MJ} / \mathrm{kg}$.

The term $\left(\frac{S}{S+\gamma}\right)_{d}^{i}$, which is the slope of the

vapor-density deficit curve, is modeled as a function of average daily air temperature by the equation

$$
\begin{aligned}
& \left(\frac{S}{S+\gamma}\right)_{d}^{i}=-13.281+0.083864\left(T A_{d}^{i}\right) \\
& -0.00012375\left(T A_{d}^{i}\right)^{2},
\end{aligned}
$$

where $T A_{d}^{i}$ is defined in equation 8. Equation 12 was defined by using parameter values obtained from a regression on data from Campbell (1977; table A.3) and provides an indication of the relative effect of air temperature on potential evapotranspiration, which varies for different temperature ranges.

Variable $\alpha$ is set equal to 1.0 in the POTEVAP subroutine (instead of 1.26) and later modified in the ETINFIL subroutine to account for soil-water-content conditions to derive an actual evapotranspiration value for each day and grid location. The modifications to $\alpha$ are described below in the section on the ETINFIL subroutine.

The available energy is $\left((R n)_{d}^{i}-G_{d}^{i}\right)$. Variable $(R n)_{d}^{i}$, total daily net incoming radiant energy, is the primary component of the energy balance. It is assumed for INFIL3.0 that $G_{d}^{i}$ is about 0 for most cases for a daily time step; therefore, $G_{d}^{i}$ is set equal to 0 . Potential evapotranspiration is calculated on an hourly time step (hstep $=1.0$ hours) or a time step defined by the user and added over a period of 1 day to obtain an estimate of total daily potential evapotranspiration, which is then used as input for calculating actual evapotranspiration in the root zone.

Cloud cover is a variable affecting the energy-balance calculation and is indirectly accounted for in the model as an empirical function of the magnitude of daily precipitation. The assumption is that the energy for evapotranspiration is reduced in the presence of clouds (associated with precipitation); the greater the rainfall, the less the evapotranspiration. For days with precipitation, the modeled clear-sky potential evapotranspiration $\left((P E T)_{d}^{i}\right)$ is reduced by the equation

$$
(\text { PETRS })_{d}^{i}=\frac{(P E T)_{d}^{i}}{\left((P E T A D J)(P P T)_{d}^{i}+1\right)},
$$

where

$(\text { PETRS })_{d}^{i} \quad$ is the adjusted rate of potential evapotranspiration at grid location $i$ and day $d$ for days on which there is precipitation, in millimeters;

$(P E T)_{d}^{i} \quad$ is the (unadjusted) rate of potential evapotranspiration at grid location $i$ and day $d$, in millimeters;

$(P E T A D J) \quad$ is an empirical adjustment factor to the unadjusted potential evapotranspiration to account for cloud cover and precipitation, in millimeters ${ }^{-1}$; and

$(P P T)_{d}^{i} \quad$ is the rate of precipitation at grid location $i$ and day $d$, in millimeters per day.

Variable (PETADJ) is specified by the model user (by variable petadj) in the Simulation-Control File. A value of petadj equal to about 0.16 has been shown to be effective in previous modeling studies (Hevesi and others, 2003). It should be noted that equation 13 is a highly empirical method to quantify the effects of cloud cover and precipitation on potential evapotranspiration, and that the relation between cloud cover, precipitation, and potential evapotranspiration is an area of active research. In particular, equation 13 may not be appropriate for climates with persistently dense cloud cover during periods with little to no precipitation (for example, climates characterized by frequent fog, such as coastal areas).

An additional potential evapotranspiration term-an approximate potential evapotranspiration estimated on the basis of vegetation cover, bare-soil area, and the PriestleyTaylor $\alpha$ coefficients-is calculated by the model. This approximate potential evapotranspiration is printed to several of the output files but is not used in any other calculations by INFIL3.0. The approximate potential evapotranspiration value is calculated as

$$
\begin{aligned}
& (\text { PET } 3)_{d}^{i}=\left\{\left(V_{E G C O V}^{i}\right)(\text { SOILET } 2)\right. \\
& \left.+\left(1-V E G C O V^{i}\right)(\text { BARSOIL } 2)\right\}(\text { PET })_{d}^{i},
\end{aligned}
$$

where

$(\text { PET3 })_{d}^{i} \quad$ is the approximate potential evapotranspiration, in millimeters; 
$(P E T)_{d}^{i} \quad$ is the (unadjusted) rate of potential evapotranspiration at grid location $i$ and day $d$, in millimeters;

$V E G C O V^{i}$ is the estimated vegetation cover for cell $i$, in decimal percent;

SOILET2 is the $\alpha$ soil-transpiration coefficient, dimensionless; and

BARSOIL2 is the $\alpha$ bare-soil coefficient, dimensionless.

The user can override the calculations of potential evapotranspiration by using variable ietval, which is specified in the Simulation-Control File. If ietval is set to a value of 1 , the user can specify a constant potential evapotranspiration for all days of the simulation by assigning a value to variable etval in the Simulation-Control File. Also, the user can adjust the values of potential evapotranspiration by the methods described previously or by using etval, which is based on the multiplication factor etfact, during model calibration. Variable etfact is specified in the Simulation-Control File.

\section{Snowfall, Snow Accumulation, Snowmelt, and Sublimation (Subroutine SNOW)}

The user has the option of simulating snowfall, snow accumulation, snowmelt, and sublimation with the SNOW subroutine if variable isnow in the Simulation-Control File is specified as 2 ; otherwise, if isnow is set to 0 , all precipitation is assumed to be rain for all days of the simulation.

If the SNOW subroutine has been activated, precipitation is simulated as rain $\left(R A I N_{d}^{i}\right)$ for a grid-cell location if the average air temperature calculated for a day is greater than $0^{\circ} \mathrm{C}$; otherwise, precipitation for that day is simulated as snow $\left(S N O W_{d}^{i}\right)$. Because air temperature is distributed spatially by the elevation-correlation model, however, snowfall and snowpack accumulation may occur in some areas of the modeled watershed while rain occurs simultaneously in other areas of the watershed.

Daily snowfall is added to the snowpack-storage term in the daily water balance. Snowpack storage accounts for the water stored in the snowpack (that is, a water-equivalent depth of snow, in millimeters) and is based on snowfall accumulation and losses from snowmelt and sublimation. Snowpack storage is carried over as an antecedent condition for the following day's water-balance calculation.

When the daily maximum air temperature is higher than freezing $\left(0^{\circ} \mathrm{C}\right)$ and snow cover is present, an empirical temperature-index model is applied to calculate the daily snowmelt (Gray and Prowse, 1993; equation 7.3.14). The snowpack is reduced by this quantity. The two components of the empirical model depend on the day of the year:

$$
(M E L T)_{d}^{i}=(S N O P A R 1)(T M A X)_{d}^{i}
$$

applies when the day of the year is greater than or equal to (SNODAY1) and less than (SNODAY2), and

$$
(M E L T)_{d}^{i}=(S N O P A R 2)(T M A X)_{d}^{i}
$$

applies for the remaining days of the year. In equations $15 \mathrm{a}$ and $15 \mathrm{~b}$,

$(M E L T)_{d}^{i} \quad$ is the quantity of snowmelt for day $d$ for cell $i$, in millimeters per day;

SNOPAR1 is the snowmelt-rate parameter that corresponds to the early-spring snowmelt period, in millimeters per day per degrees Celsius;

SNOPAR2 is the snowmelt-rate parameter that corresponds to the late-spring snowmelt period, in millimeters per day per degrees Celsius;

SNODAY1 is the starting (Julian) day for the timing of the early-spring snowmelt period;

SNODAY2 is the starting (Julian) day for the timing of the late-spring snowmelt period; and

$(T M A X)_{d}^{i} \quad$ is the daily maximum air temperature for cell $i$, in degrees Celsius.

Variables snopar1, snopar2, snoday1, and snoday2 are specified by the model user in the Simulation-Control File. If $(M E L T)_{d}^{i}$ is greater than the available snowpack, then $(M E L T)_{d}^{i}$ is set to the quantity of snowpack (multiplied by the 1-day time step). Example values for variables snopar1 and snopar2 are given in table 7.3.7 of Gray and Prowse (1993) and in the sample problem described later in this report.

Sublimation is calculated when variable isublim is set to a value of 1 in the Simulation-Control File. Sublimation is calculated on the basis of an empirical function of the adjusted potential evapotranspiration. For average air temperature less than or equal to $0^{\circ} \mathrm{C}$, the function is

$$
(S U B L I M)_{d}^{i}=(S U B P A R 1)(P E T R S)_{d}^{i},
$$

and for average air temperature greater than $0^{\circ} \mathrm{C}$, the function is

$$
(\text { SUBLIM })_{d}^{i}=(\text { SUBPAR2 })(\text { PETRS })_{d}^{i} .
$$

In equations $16 \mathrm{a}$ and $16 \mathrm{~b}$,
$(\text { SUBLIM })_{d}^{i} \quad$ is the sublimation for day $d$ for cell $i$, in millimeters;
$(\text { PETRS })_{d}^{i} \quad$ is the adjusted rate of potential evapo- transpiration for day $d$ and cell $i$, in millimeters; and

(SUBPAR1) and (SUBPAR2) are dimensionless sublimation variables.

Variables subpar1 and subpar2 are set by the model user in the Simulation-Control File and may be adjusted during model calibration. Values of subpar1 and subpar 2 between 0.1 and 0.4 have been used in previous investigations (Hevesi 
and others, 2003; Nishikawa and others, 2004; L.E. Flint, U.S. Geological Survey, written commun., April 2007). Typically, values of subpar1 and subpar 2 in this range result in average annual sublimation losses of about 5 to 20 percent of precipitation falling as snow, with the highest relative losses just above the snowline where average air temperature is just above freezing. The approach used to simulate sublimation in INFIL3.0 is highly simplified; in actuality, sublimation depends on several factors that are not accounted for in INFIL3.0, such as relative humidity and wind speed.

If sublimation has occurred, then the adjusted rate of potential evapotranspiration is updated by the rate of sublimation

$$
(\text { PETRS })_{d}^{i}=(\text { PETRS })_{d}^{i}-(S U B L I M)_{d}^{i}
$$

where $(P E T R S)_{d}^{i}$ and $(S U B L I M)_{d}^{i}$ are defined previously.

\section{Infiltration, Drainage, Evapotranspiration, and Runoff (Subroutine ETINFIL)}

The root-zone water-balance calculation uses a twostep process to couple surface-water flow with the processes of infiltration, drainage, and evapotranspiration. The first step is done by subroutine ETINFIL and the second step by subroutine SWINFIL. ETINFIL has four primary steps, which are completed for each grid cell for each day: (1) calculation of infiltration to the root zone from rain and snowmelt and an initial calculation of runoff equal to rain and snowmelt in excess of the infiltration capacity of the soil or bedrock (that is, a Hortonian-runoff process caused by excess infiltration when the rate of rain and snowmelt exceeds the infiltration capacity of the surface materials); (2) redistribution of infiltration by downward drainage through all layers of the root zone and an initial calculation of the change in soilwater storage in each layer of the root zone; (3) calculation of evapotranspiration from each layer of the root zone; and (4) final calculations of net infiltration, change in soil-water storage in each layer of the root zone, and runoff from the grid cell. (This second runoff component represents a Dunnianrunoff process caused by excess saturation when the root zone is fully saturated.)

In the remainder of the report, many references are made to the hydraulic conductivity of the soil and bedrock layers. In all cases, these references are to the vertical hydraulic conductivity of the materials.

\section{(1) Infiltration and Initial Calculation of Runoff}

Depending on soil depth, either the soil or the bedrock saturated hydraulic conductivity is used to calculate (1) the maximum infiltration to the root zone from rain and snowmelt and (2) an initial calculation of runoff equal to the quantity of rain and snowmelt that is in excess of the infiltration capacity of the soil or bedrock. The infiltration capacity of the soil and bedrock for each grid cell is calculated on the basis of the saturated hydraulic conductivity of the soil or bedrock. The conductivity value is modified by the duration of the rain or snowmelt. For summer rainstorms (between Julian days dysumbeg and dysumend, which are program variables defined by the user in the Simulation-Control File), the resulting infiltration capacity is calculated by

$$
I C_{p}=\frac{\text { Ksat }}{24 / \text { stormsum }},
$$

whereas for winter rainstorms, the modified saturated hydraulic conductivity is calculated by

$$
I C_{p}=\frac{\text { Ksat }}{24 / \text { stormwin }} .
$$

In equations $18 \mathrm{a}$ and $18 \mathrm{~b}$,

$I C_{p} \quad$ is the infiltration capacity for either soil or bedrock for rain, in millimeters;

Ksat is the original saturated hydraulic conductivity for either soil or bedrock, in millimeters per day; and

stormsum and stormwin are the duration, in hours, of summer and winter storms, respectively.

The conversion factor 24 (hours/day) converts the units of hydraulic conductivity from millimeters per day to a raininfiltration capacity in millimeters. Variables stormsum and stormwin are specified by the user in the SimulationControl File.

An equivalent equation is used to calculate infiltration capacities for soil and bedrock for snowmelt:

$$
I C_{m}=\frac{\text { Ksat }}{24 / \text { melttime }}
$$

where

$I C_{m} \quad$ is the infiltration capacity for either soil or bedrock for snowmelt, in millimeters;

melttime is the estimated duration, in hours, of the daily snowmelt period; and

Ksat is defined previously.

As is done for rain, the conversion factor 24 (hours/day) converts the units of hydraulic conductivity in millimeters per day into a snowmelt-infiltration capacity in millimeters. Variable melttime is specified by the user in the SimulationControl File.

The maximum quantities of rain and snowmelt that can infiltrate into the soil or bedrock at a particular cell are $I C_{p}$ and $I C_{m}$, respectively. If the quantities of rain and snowmelt are below $I C_{p}$ and $I C_{m}$, then the infiltration to the root zone is the sum of the rainfall and snowmelt for the cell for that day. Also note that it is assumed that when rain occurs directly to a snowpack, the rain goes directly through the snowpack and infiltrates into the underlying soil or bedrock; that is, the 
physics of the rain-on-snow process is simplified such that rain infiltrates as if there was no snowpack present. Finally, the initial runoff for the cell, Roff $1^{i}$, is calculated as the sum of the quantities of rain and snowmelt that are in excess of $I C_{p}$ plus $I C_{m}$.

\section{(2) Drainage and Redistribution in the Root Zone and Initial Calculation of Change in Soil-Water Storage}

Infiltration from rain and snowmelt is redistributed downward through the soil layers by drainage when the thickness of the soil zone is greater than zero. Each soil layer has an initial soil-water content that is equal to the previous day's final water content. For the first day of a simulation, the initial soil-water content is specified for each grid cell on the basis of factors specified in the input files (see section above on "Model Time Steps and Initial Conditions"). For layer 1, the initial soil-water content is added to the infiltration to the root zone from rain and snowmelt; this sum is the total soil-water content for the layer.

Downward drainage is calculated beginning with the top layer. First, a calculation is made to determine if the total water content for the top layer minus the infiltration capacity of the underlying layer is greater than the maximum storage limit for the top layer. The maximum storage limit for the layer is equal to the product of the soil or rock porosity and the thickness of the soil layer (in millimeters). If the total soilwater content for the layer minus the infiltration capacity of the underlying layer is greater than or equal to the maximum storage limit (that is, the layer is saturated), then drainage to the second layer is set equal to the infiltration capacity of the soil. The total soil-water content for layer 1 (top layer) is then updated by subtracting the quantity drained to layer 2 . If, however, the total soil-water content for the layer minus the infiltration capacity for the layer is less than the maximum storage limit (that is, the layer is unsaturated), then downward drainage to the second layer is calculated by using a modified form of an empirical drainage model in Jury and others (1991; pp. 144-150) for approximating water contents and the depth of the wetting front in a draining soil profile. The empirical drainage model is based on the following equations:

$$
D R_{j}^{i}=\left(V W C A_{j}^{i}-V W C B_{j}^{i}\right)\left(T H C K_{j}^{i}\right)(1,000),
$$

where

$$
\begin{aligned}
D R_{j}^{i} & \begin{array}{c}
\text { is drainage through layer } j \text { into layer } j+1 \text { at } \\
\text { grid location } i, \text { in millimeters; and }
\end{array} \\
T H C K_{j}^{i} & \begin{array}{l}
\text { is the thickness of layer } j \text { at grid location } i, \\
\text { in meters. }
\end{array}
\end{aligned}
$$

The conversion factor 1,000 (millimeters/meter) converts the units of thickness from meters to millimeters.

$V W C A_{j}^{i}$ is the initial volumetric water content, calculated by the equation

$$
V W C A_{j}^{i}=\left(G A 2_{j}^{i}\right)\left(G T_{j}^{i}+G C 2_{j}^{i}\right)^{-G B^{i}},
$$

and $V W C B_{j}^{i}$ is the final volumetric water content calculated by the equation

$$
V W C B_{j}^{i}=\left(G A 2_{j}^{i}\right)\left[\left(G T_{j}^{i}+1\right)+G C 2_{j}^{i}\right]^{-G B^{i}} .
$$

The additional terms in equations $21 \mathrm{a}$ and $21 \mathrm{~b}$ are defined by

$$
\begin{gathered}
G A 2_{j}^{i}=\left\{\left(\operatorname{SPOR}_{j}^{i}\right)^{\left(G N^{i}+1\right)}\right. \\
\left.\left[\left(T H C K_{j}^{i}\right)(1,000) /\left(G N^{i}\right)\left(K S a t_{j}^{i}\right)(\Delta t)\right]\right\}^{1 / G N^{i}}, \\
G T_{j}^{i}=\left[\left(V W C C_{j}^{i} / G A 2_{j}^{i}\right)^{\left(1 /-G B^{i}\right)}\right]-G C 2_{j}^{i}, \\
G C 2_{j}^{i}=\left[\left(T H C K_{j}^{i}\right)(1,000)\left(S P O R_{j}^{i}\right)\right] /\left[\left(G N^{i}\right)\left(K S a t_{j}^{i}\right)(\Delta t)\right], \\
G N^{i}=(2)\left(S O I L B^{i}\right)+3, \\
G B_{j}^{i}=1 / G N^{i}, \\
V W C C_{j}^{i}=S O I L M M_{j}^{i} / T H C K_{j}^{i} / 1,000
\end{gathered}
$$

where

$\operatorname{SPOR}_{j}^{i} \quad$ is the porosity of the soil for layer $j$ at grid location $i$, dimensionless;

$K s a t_{j}^{i} \quad$ is the saturated hydraulic conductivity of the soil for layer $j$ at grid location $i$, in millimeters per day;

$\Delta t \quad$ is a time step, which for INFIL3.0 is equal to 1 day;

$\operatorname{SOILB}^{i} \quad$ is the soil-drainage-function coefficient for grid location $i$, dimensionless; and

$\operatorname{SOILMM}_{j}^{i} \quad$ is the simulated soil-water content for layer $j$ at grid location $i$, in millimeters.

Downward drainage through the remaining soil layers is then calculated by using the same sequence of steps. In each case, the maximum quantity of water that can drain from one layer to the next is the infiltration capacity calculated by equation $18 \mathrm{a}$ or $18 \mathrm{~b}$. Any water that is in excess of the infiltration capacity and does not drain to the underlying layer is held in a temporary storage term for the layer. This water is used in subsequent calculations to calculate runoff and the final distribution of water in the root zone after abstraction by evapotranspiration.

\section{(3) Evapotranspiration from Each Layer of the Root Zone}

Evapotranspiration from each layer is calculated by using a modified form of the Priestley-Taylor equation and the updated soil-water content calculated by the 
downward-drainage function for each layer. The modified Priestley-Taylor equation relates the empirical coefficient in equation $10, \alpha$, to seasonal changes in soil-water content (Davies and Allen, 1973; Flint and Childs, 1991). This modified version has been used successfully in arid and semiarid environments (de Bruin, 1988; Stannard, 1993). When expressed as a function of soil-water content, $\alpha$ is replaced by $\alpha^{\prime}$ in the equation

$$
\alpha^{\prime}=\alpha\left(1-e^{\beta \Theta}\right)
$$

where $\alpha$ and $\beta$ are coefficients, and $\Theta$ is relative saturation.

The relative saturation $\Theta$ is defined as

$$
\Theta=\frac{\left(\theta-\theta_{r}\right)}{\left(\theta_{s}-\theta_{r}\right)},
$$

where

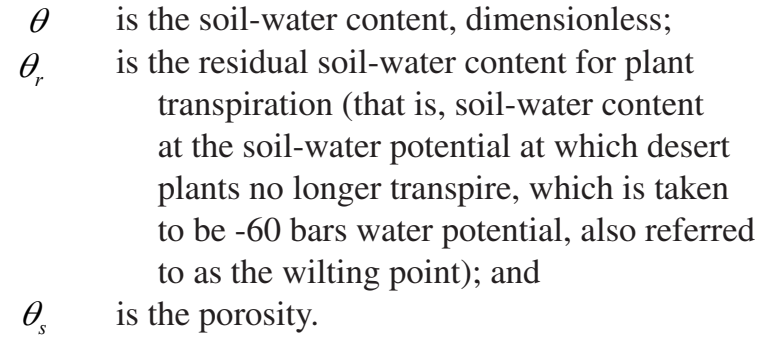

The modified Priestley-Taylor equation is used to calculate both bare-soil evaporation and plant transpiration. Baresoil-evaporation demand is simulated first from the top two model layers that have nonzero thickness. For the top layer of the model, the modified Priestley-Taylor equation is

$$
B S E_{1}^{i}=\left\{B A R S O I L 2\left[1-e^{(B A R S O I L I)\left(\Theta_{1}^{i}\right)}\right]\right\}\left(P E V A P_{1}\right)
$$

where

$B S E_{1}^{i} \quad$ is the daily evaporation for layer 1, in millimeters;

$B A R S O I L 2 \quad$ is the $\alpha$ bare-soil coefficient, dimensionless;

$B A R S O I L 1 \quad$ is the $\beta$ bare-soil coefficient, dimensionless;

$\Theta_{1}^{i} \quad$ is the relative saturation for layer 1 , dimensionless; and

PEVAP $P_{1}$ is the modified potential evaporation, in millimeters.

Variables BARSOIL1 and BARSOIL2 are specified by the model user in the Simulation-Control File (barsoil1 and barsoil2). Variable $P E V A P_{1}$ for layer 1 is defined by

$$
\operatorname{PEVAP}_{1}=\left(1-V E G C O V^{i}\right)\left(\operatorname{PETRS}_{d}^{i}\right),
$$

where

$V E G C O V^{i} \quad$ is the estimated vegetation cover for cell $i$, in decimal percent; and
$\operatorname{PETRS}_{d}^{i}$
is the adjusted rate of potential evapotranspiration at grid location $i$ and day $d$ for days on which there is precipitation, in millimeters.

For the second layer of the model, the equation is

$$
B S E_{2}^{i}=\left\{\text { BARSOIL } 2\left[1-e^{(B S E F)(B A R S O I L 1)\left(\Theta_{2}^{i}\right)}\right]\right\}\left(P E V A P_{2}\right),
$$

where

$B S E_{2}^{i} \quad$ is the daily bare-soil evaporation from layer 2, in millimeters;

$B S E F \quad$ is an adjustment factor specified by the user (variable barsoilf in the SimulationControl File) to modify the value of $B A R S O I L 1$ used for layer 1 (a value of $B S E F$ equal to 1.0 causes the BARSOIL1 values for layers 1 and 2 to be the same), dimensionless; and

$\Theta_{2}^{i} \quad$ is relative saturation for layer 2, dimensionless.

Variable $P E V A P_{2}$ for layer 2 is defined by

$$
\operatorname{PEVAP}_{2}=\left(P E V A P_{1}\right)-\left(B S E_{1}^{i}\right)
$$

After bare-soil evaporation demand has been met, the modified form of the Priestley-Taylor equation then is used to simulate plant transpiration from all six model layers. The simulation of transpiration uses weighting factors $\left(W G T_{j}^{i}\right)$ that account for root density and the distribution of available water in each of the root-zone layers. For the top five soil layers, the modified Priestley-Taylor equation is

$$
\operatorname{TRANS}_{j}^{i}=W G T_{j}^{i}\left\{\operatorname{SOILET} 2\left[1-e^{(\operatorname{SOILET1})\left(\Theta_{j}^{i}\right)}\right]\right\}(\operatorname{PTRANS}),
$$

where

$$
\begin{aligned}
& \operatorname{TRANS}_{j}^{i} \begin{array}{r}
\text { is the daily transpiration from layer } j, \\
\text { in millimeters; } \\
W G T_{j}^{i}
\end{array} \\
& \text { is the weighting factor for layer } j, \\
& \text { dimensionless; } \\
& \text { is the } \alpha \text { soil-transpiration coefficient, } \\
& \text { dimensionless; } \\
& \text { SOILET1 } \quad \begin{aligned}
\text { is the } \beta \text { soil-transpiration coefficient, } \\
\text { dimensionless; }
\end{aligned} \\
& \Theta_{j}^{i} \quad \begin{array}{l}
\text { is relative saturation for layer } j, \\
\text { dimensionless; and }
\end{array} \\
& \text { is the modified potential evaporation, } \\
& \text { in millimeters. }
\end{aligned}
$$

Variables SOILET1 and SOILET2 are specified by the model user in the Simulation-Control File (variables soilet1 and soilet2). Variable PTRANS in equation 34 is defined by

$$
\text { PTRANS }=\left(\text { VEGCOV }^{i}\right)\left(\operatorname{PETRS}_{d}^{i}\right)
$$


An equation similar to equation 34 is used to calculate transpiration from the bedrock layer, except that variables SOILET1 and SOILET 2 are replaced by variables ROCKET1 and ROCKET2, which are specified by the model user in the Simulation-Control File (rocket1 and rocket2).

The weighting factors, $W G T_{j}^{i}$, for each layer of the model are calculated from

$$
W G T_{j}^{i}=\left(\Theta_{j}^{j}\right)\left(R Z D E N_{j}^{i}\right) / \sum_{j=1}^{6}\left(\Theta_{j}^{j}\right)\left(R Z D E N_{j}^{i}\right)
$$

where

$$
\begin{aligned}
\Theta_{j}^{j} & \begin{array}{c}
\text { is the relative saturation for each layer } j, \\
\text { dimensionless; and }
\end{array} \\
R Z D E N_{j}^{i} & \begin{array}{c}
\text { is the root-density factor for layer } j \text { at cell } i, \\
\text { in decimal percent. }
\end{array}
\end{aligned}
$$

The variables $R Z D E N_{j}^{i}$ are based on the values of vegetation cover specified as a percentage for each of the six layers of the model in the Vegetation-Properties File (variable vegcover(6)) and converted to decimal percent in ETINFIL. The sum of the weights for the six layers of the model will be 1.0. If any of the weighting factors for a layer calculated in equation 36 is greater than the corresponding root-density factor for that layer, then the respective final weight is reset to the rootdensity factor for that layer.

The total evapotranspiration within the six model layers, $E T_{d}^{i}$, is equal to

$$
E T_{d}^{i}=B S E_{1}^{i}+B S E_{2}^{i}+\sum_{j=1}^{6} T R A N S_{j}^{i}
$$

\section{(4) Final Calculations of Net Infiltration, Change in Water Storage in Each Layer of the Root Zone, and Runoff from the Grid Cell}

Rain or snowmelt drains into layer 6 (the bedrock layer) either directly when a soil zone is absent, or from the bottom layer of the soil zone. If a bedrock layer is present (that is, the thickness of layer 6 is greater than zero), net infiltration (that is, drainage below layers 1-6 of the model) is calculated on the basis of the water content and hydraulic conductivity of the bedrock layer. If the sum of drainage into the bedrock layer and existing water content, minus the saturated hydraulic conductivity of the bedrock, is greater than the available storage capacity of the bedrock ${ }^{1}$, net infiltration is equal to the saturated hydraulic conductivity of the bedrock (variable imbibe2, which is specified in the Bedrock-Properties File). If, however, the sum of the quantity of drainage into the bedrock layer and the existing water content is greater than zero but less than the available storage capacity of the bedrock (that is, the bedrock layer is unsaturated), then the quantity of net infiltration is equal to the unsaturated hydraulic conductivity

\footnotetext{
${ }^{1}$ The storage capacity of the bedrock equals the product of the bedrock porosity and bedrock thickness (in millimeters).
}

of the bedrock (variable imbibe, which is specified in the Bedrock-Properties File). After net infiltration has been calculated, the remaining quantity of water in the bedrock layer is calculated by subtracting net infiltration from the initial water in the bedrock layer.

If the root zone is underlain by thick soil (or unconsolidated deposits), it would typically be modeled as having five soil layers and a maximum root-zone thickness. In this case, the thickness of the bedrock layer is zero, because the root zone is underlain by unconsolidated deposits as opposed to consolidated rock (the bedrock layer is absent). If the bedrocklayer thickness is zero, the net-infiltration rate is limited only by the estimated saturated hydraulic conductivity of the underlying materials (imbibe2). The imbibe 2 parameter will become a limiting factor only if the simulated drainage rate through the overlying soil layer is greater than the saturated hydraulic conductivity defined by imbibe2.

Excess water in the root zone, which contributes to surface-water runoff $\left(\operatorname{Roff} 2_{d}^{i}\right)$ as a saturated-excess or Dunnianrunoff component, is calculated by a redistribution algorithm that steps sequentially upward through all root-zone layers. To simulate $R o f f 2_{d}^{i}$ and the final water content of each of the five soil layers $\left(\operatorname{SOILMM}_{j}\right)$ and bedrock layer, $($ ROCKMM $)$ the storage capacity of each layer is checked against the quantity of water held in the temporary-storage term for each layer. If the temporary-storage variable exceeds the storage capacity of the layer, the excess water is added to the overlying layer. The algorithm moves sequentially upward through the root-zone layers until all excess water held in temporary storage has been redistributed to overlying layers that have available storage capacity. If excess water remains after the upward redistribution has reached the top soil layer, the excess water is added to the runoff term. The runoff generated by the upward-redistribution process represents the fraction of inflowing water that exceeds the storage capacity of the root zone. Total runoff, Roff $f_{d}^{i}$, for each cell is thus the sum of the excess root-zone water $\operatorname{Roff}{ }_{d}^{i}$ and the initial runoff $\operatorname{Roff} 1_{d}^{i}$ calculated as excess rainfall and snowmelt.

The last calculation in the subroutine is the change in total water storage of all six layers of the model,

$$
\sum_{j=1}^{6}\left(\Delta W_{d}^{i}\right)_{j}
$$

which is equal to the final storage of all six layers $(j=1$ through 6) minus the initial storage at the beginning of the call to the subroutine.

\section{Surface-Water Routing (Subroutine SWINFIL)}

Subroutine SWINFIL routes daily runoff $\operatorname{Roff}_{d}^{i}$ (calculated in subroutine ETINFIL) to downstream cells as surface-water run-on, $\operatorname{Ron}_{d}^{i}$. During the routing process, run-on can infiltrate back into the root zone and contribute to daily net infiltration (variable $\operatorname{Ron}_{d}^{i}$ in equation 1) when 
variable irout is specified as 1 in the Simulation-Control File. Surface-water flow therefore can be coupled to the root-zone water balance by the infiltrated run-on component. The user also has the option of not allowing surface-water run-on to infiltrate back into the root zone by specifying variable irout equal to 0 .

For each daily time step, SWINFIL is invoked if runoff has been generated at any model-grid location by ETINFIL. If runoff has not been calculated, SWINFIL is skipped and the simulation is continued to the next day. If there is runoff, the routing algorithm loops through the drainage-basin grid in the order in which the cells have been entered in the Geospatial Watershed-Characteristics File-from the lowest to the highest value of variable locid specified for each grid cell in the Geospatial Watershed-Characteristics File. Runoff from a cell is routed as run-on to the downstream cell identified by variable iwat in the Geospatial Watershed-Characteristics File, with variables locid and iwat acting as pointers to connect upstream and downstream cells. (A cell identified by a value of iwat equal to -3 is the outflow cell of the basin.) Each cell provides runoff to only one downstream cell, but may receive runoff from multiple upstream cells. Also, if upstream basins contribute runoff, this runoff is added to the cell that receives the upstream flow, and is then routed downstream.

It should be noted that SWINFIL is based on the assumption that for any daily time step, all runoff generated within the model domain is either infiltrated back into the root zone or is discharged as surface-water outflow from the model domain. The calculated surface-water outflow would not be representative of study areas characterized by lag times of several days or longer between the generation of runoff and subsequent outflow. A longer lag time may result in greater relative channel losses and attenuation compared to the simulated 1-day lag time for surface-water outflow. Model calibration also could be affected if multiday lag times affect measured streamflow used for model calibration.

The user can specify the fraction of each grid-cell area that is wetted by run-on (that is, the effective flow-area fraction of the grid cell). This fraction is used to scale the hydraulic conductivities of the soil and bedrock of the grid cell. Two options to determine the fraction of each grid-cell area that is wetted by run-on are provided by the assignment of two possible values of ichanmod specified in the Simulation-Control File. If ichanmod is set to a value other than 1 , the fraction of the grid-cell area that is wetted, FLAREA ${ }^{i}$, is set to a constant value defined by

$$
F L A R E A^{i}=C H A N 1
$$

If, however, ichanmod is set to 1 , an empirical model is used to define the effective flow-area fraction as a function of the upstream area, the quantity of surface-water inflow, and the slope of the grid cell:

$$
\begin{aligned}
& \text { FLAREA } A^{i}=\text { CHAN } 1+ \\
& {\left[\left(U P C E L L S^{i} \times F L O W I N^{i}\right)^{\left(\left(1-S L 2^{i}\right) / 2\right)}\right] /} \\
& \text { CHAN2 + CHAN3-UPCELLS } S^{i} / 4
\end{aligned}
$$

if $F L A R E A^{i} \leq C H A N 4$, and

$$
F L A R E A^{i}=C H A N 4
$$

if $F L A R E A^{i}>C H A N 4$. In equations 39a and 39b,
CHAN1
is the surface-water minimum effective wetted-flow area, in decimal percent;
CHAN2 is the surface-water wetted-flow area factor, dimensionless;
CHAN3 is the surface-water maximum headwater wetted-flow area, dimensionless;
CHAN4 is the surface-water maximum effective wetted-flow area per grid cell, as a decimal percent of the area of each grid cell;
$S L 2^{i} \quad$ is the slope of grid cell $i$, in decimal percent; $U P C E L L S^{i} \quad$ is the number of cells upstream to grid location $i$, dimensionless; and
$F_{L O W I N}{ }^{i}$ is the simulated surface-water run-on for grid location $i$, in millimeters.

Variables chan1, chan2, chan3, and chan4 are specified by the user in the Simulation-Control File; representative values for these four variables are given in the sample problem. The headwater-flow area (CHAN3) is used to represent upland areas where overland-flow processes are more important than channel flow. For low-flow conditions, steep channels, or small upstream areas, the effective flow area is defined by the CHAN1 coefficient in equation 39a. The effective flow area increases as a continuous function and approaches or equals the CHAN4 coefficient as the surface-water run-on depth increases, the channel gradient decreases, and the number of upstream cells (and thus upstream area) increases. To account for dispersive flow across alluvial fans, the CHAN4 coefficient can be set to a value greater than 1 , allowing the effective flow area to be greater than the grid-cell area.

FLAREA $A^{i}$ is used to adjust (scale) the soil and bedrock hydraulic conductivities of each grid cell. For the soil hydraulic conductivity, $\mathrm{Ksat}_{\text {soil }}$, the equation to calculate an adjusted soil hydraulic conductivity, $\left(K_{s a t} t_{\text {soil }}\right)_{a d j}$, is

$$
\left(\text { Ksat }_{\text {soil }}\right)_{a d j}=\left(\text { Ksat }_{\text {soil }}\right)(S K S F A C T)\left(F L A R E A^{i}\right) .
$$

For both the unsaturated and saturated bedrock hydraulic conductivities, $\mathrm{Ksat}_{\text {rock }}$, the equation to calculate an adjusted bedrock hydraulic conductivity, $\left(K s a t_{r o c k}\right)_{a d j}$, is

$$
\left(K s a t_{\text {rock }}\right)_{a d j}=\left(K s a t_{\text {rock }}\right)(I M B F A C T)\left(F L A R E A^{i}\right),
$$


where in equations $40 \mathrm{a}$ and $40 \mathrm{~b}$

SKSFACT is a scaling factor for soil hydraulic conductivity, dimensionless; and

IMBFACT is a scaling factor for unsaturated and saturated bedrock hydraulic conductivity, dimensionless.

Variables sksfact and imbfact are specified in the SimulationControl File, and can be used during model calibration to adjust the hydraulic conductivity values as needed.

To account for differences in soil hydraulic conductivity between channel and interchannel locations (for example, channel beds may contain coarser, more permeable material), the adjusted soil hydraulic conductivity for a grid cell can be further scaled for stream-channel locations by using variable $K s c h n^{i}$. The resulting hydraulic conductivity, $\left(K_{s a t}{ }_{\text {soil }}\right)_{\text {schn }}$, is calculated as

$$
\left.\left(K_{s a t}\right)_{s o i l}\right)_{s c h n}=\left(K s a t_{s o i l}\right)_{a d j}\left(K s c h n^{i}\right)
$$

$K s c h n^{i}$ is initially set to a value of 1.0 but can be updated by the use of three variables, kschn1, kschn2, and kschn3 that are specified in the Simulation-Control File. The first variable, kschn1, is the minimum number of cells upstream to a grid cell that are needed for an adjustment to take place. If the user specifies kschn1 to be very high, then equation 41 , with $K s c h n^{i}$ equal to 1.0, will automatically be used. If, however, the number of cells upstream to a grid cell is greater than kschn1, then $K s c h n^{i}$ will be modified depending on the value of ikschnmod specified by the user in the Simulation-Control File. If ikschnmod is set to 0 , then

$$
K \operatorname{sch} n^{i}=K \operatorname{schn} 3,
$$

where $K s c h n 3$ is the maximum adjustment factor to the soil hydraulic conductivity. If, however, ikschnmod does not equal 0 , then

$$
K s c h n^{i}=\left(\left(U P C E L L S^{i}-K s \operatorname{chn} 1\right) / K s c h n 2\right)+1,
$$

where $K s c h n 2$ is the scaling factor for adjusting the saturated hydraulic conductivity for soil in channels. If the value of $K s c h n^{i}$ calculated by equation 43 exceeds $K s c h n 3$, then $K s c h n^{i}$ is set equal to Kschn3.

The final adjustment that is made to the soil and bedrock saturated hydraulic conductivities is their conversion to infiltration capacities based on the duration of summer and winter rain storms, as was done in the ETINFIL subroutine. For summer storms, the equation is

$$
I C_{p}=\frac{\text { Ksat }}{24 / \text { stormsum }},
$$

whereas for winter storms, the equation is

$$
I C_{p}=\frac{\text { Ksat }}{24 / \text { stormwin }}
$$

where in equations $44 \mathrm{a}$ and $44 \mathrm{~b}$

$I C_{p} \quad$ is the infiltration capacity for either soil or bedrock for rain, in millimeters; and

Ksat is the saturated hydraulic conductivity for either soil $\left(\left(K_{s a t} t_{\text {soil }}\right)_{a d j}\right.$ or $\left.\left(K s a t_{\text {soil }}\right)_{\text {schn }}\right)$ or bedrock $\left(\left(K_{s a t_{\text {rock }}}\right)_{a d j}\right)$, in millimeters per day.

Variables stormsum and stormwin are defined in equation 18. The conversion factor 24 hours/day converts the units of hydraulic conductivity in millimeters per day into a rain-infiltration capacity in units of millimeters. Variables stormsum and stormwin are specified by the user in the Simulation-Control File. Equations $44 \mathrm{a}$ and $44 \mathrm{~b}$ are used to calculate infiltration capacity of the bedrock only if the total thickness of the soil is less than $0.1 \mathrm{~m}$; if the total thickness of the soil is greater than or equal to $0.1 \mathrm{~m}$, then equation $40 \mathrm{~b}$ is used to calculate infiltration capacity of the bedrock.

Flow duration, wetted area, and channel characteristics are represented in the INFIL3.0 model by using equations 38 through $44 \mathrm{~b}$ to scale the saturated hydraulic conductivity that controls infiltration into the root zone. For example, as the wetted area increases, the potential channel losses for streamflow increase because the $K s c h n^{i}$ term increases. As storm duration decreases, the potential channel losses for streamflow decrease because the effective streamflow intensity increases relative to the infiltration capacity of the channel.

SWINFIL uses a simplified form of the ETINFIL downward-drainage algorithm. Water drains into the root zone and underlying layers only when the overlying layer has become fully saturated. Drainage from unsaturated layers, which is simulated in ETINFIL by equations 20-27, is not simulated in SWINFIL. The maximum drainage is limited to the saturated hydraulic conductivity of the underlying layer. If the quantity of water in the bottom layer (in millimeters) is greater than the saturated hydraulic conductivity of the layer multiplied by the 1-day time step (so that the resulting units are millimeters), then net infiltration is equal to the saturated hydraulic conductivity multiplied by the 1-day time step; if, however, the quantity of water in the bottom layer is less than the saturated hydraulic conductivity multiplied by the 1-day time step, then net infiltration is equal to the quantity of water in the bottom layer. The net infiltration from surface-water run-on is defined as run-on net infiltration and is added to the total daily netinfiltration term.

After the net infiltration has been calculated, excess water in the root zone is then calculated using a redistribution algorithm that steps sequentially upward through all root-zone layers, starting at the bottom and moving up to the top layer; this redistribution algorithm is the same as that used in the ETINFIL subroutine. If excess water remains after the upward 
redistribution has reached the top soil layer, the excess water is added to the downstream-runoff term. The change in total water storage of all six layers of the model,

$$
\sum_{j=1}^{6}\left(\Delta W_{d}^{i}\right)_{j}
$$

which is equal to the final storage of all six layers minus the initial storage at the beginning of the call to SWINFIL, is then updated.

Surface-water flow that does not infiltrate into the root zone becomes surface-water discharge from the drainage basin (watershed) being modeled. In closed basins, surface water is assumed to evaporate, as where surface water discharges to a playa.

\section{Applicability and Limitations of INFIL3.0}

Earlier versions of the INFIL code were originally developed to calculate net infiltration at Yucca Mountain, Nevada. The Yucca Mountain study area, which is in the Basin and Range physiographic province, is characterized as arid to semiarid with small intermontane drainages having thin soils and sparse vegetation, and subject to intermittent runoff from infrequent rainfall and snowmelt. Subsequent modifications to the program were made to (1) allow for regional-scale simulations (in particular, simulations of the Death Valley regional-flow system) that use spatially distributed daily climate inputs, (2) allow for additional soil layers within the root zone, (3) provide a continuous drainage function for soil layers, and (4) allow for surface-water inflows from upstream catchments (Hevesi and others, 2003; Nishikawa and others, 2004; Rewis and others, 2006). These subsequent modifications have all been incorporated into INFIL3.0.

All previous model applications were done to characterize net infiltration or potential recharge for mountainous study areas in the Southwestern United States, with the primary objectives being (1) to estimate the magnitude and spatial distribution of diffuse recharge in direct response to precipitation and snowmelt over more permeable soils or rock units, (2) to estimate the magnitude and spatial distribution of recharge in response to runoff, primarily as channel losses in the more permeable streambeds, and (3) to estimate the temporal distribution of potential recharge or net infiltration in response to climate variability. All study areas for the previous applications of earlier versions of the INFIL code included thick unsaturated zones; very limited to no contribution to streamflow from ground-water discharge, but instead from Hortonian or Dunnian runoff in response to rain or snowmelt; a short lag time between runoff generation and surface-water discharge (less than 1 day for most cases); and steep terrain with thin soil cover. In general, applications of INFIL3.0 are likely to be most appropriate for study areas with similar characteristics.
If INFIL3.0 is used to estimate recharge, the role of the unsaturated zone may need to be considered. For study areas with thick unsaturated zones, the average annual potential recharge rates obtained from 30- to 70-year simulations may be representative of actual recharge, but the daily, monthly, and even annual results are likely not representative of actual recharge because of the dampening effect of the thick unsaturated zone on downward percolation. In other words, estimated net infiltration is usually highly dependent on climate variability, whereas actual recharge may be more dependent on the long-term average climate conditions and the hydrogeologic properties of the unsaturated zone.

INFIL3.0 may have limited applicability for study areas characterized by humid climates, thin unsaturated zones, perennial streamflow with significant contributions from ground-water discharge, and a high percentage of cloudy days with no precipitation (for example, coastal areas subject to foggy conditions). All streamflow simulated by INFIL3.0 is assumed to be routed through the entire study area within the 1-day time step. Therefore, study areas characterized by streamflow with a substantial lag-time relative to the generation of runoff may not be appropriate for an INFIL3.0 application. Options available in INFIL3.0 for representing channel characteristics likely to affect infiltration of routed surface water are limited to estimates of the effective wetted area and differences in hydraulic conductivity for channel versus interchannel soils. These options are based on an assumed continuous transition of channel characteristics from overland-flow conditions to narrow streambeds in loworder stream channels and to wider streambeds for higherorder channels. These limited options may not be adequate in representing more complex and variable channel and streambed characteristics for all study areas.

Although previous versions of the INFIL code have been applied to evaluate the effects of urbanization on runoff generation and subsequent potential recharge (Rewis and others, 2006), application of INFIL3.0 to highly urbanized watersheds with controlled flows, discharges, and diversions may not be appropriate (surface-water inflows from upstream areas were not intended to represent point sources such as wastewater discharges). The INFIL3.0 surface-water-routing algorithm does not include a reach storage component for surface-water storage in channel segments, retention basins, or reservoirs. In addition, INFIL 3.0 provides no interception storage term or surface-retention storage term. For some study areas with dense vegetation and forest canopy, such storage terms may be a significant component of the water balance.

An important consideration for INFIL3.0 applications is model calibration. Generally, streamflow records are used for model calibration, but matching simulated streamflow to measured streamflow does not ensure calibration for simulated net infiltration or potential recharge because simulated evapotranspiration, net infiltration, and potential recharge can vary but produce a negligible combined effect on simulated streamflow. Estimates of hourly or daily potential evapotratranspiration are sometimes available for monitoring 
sites (for example, California Irrigation Management Information System (CIMIS) stations in California), and these records can be compared to simulated potential evapotranspiration to reduce uncertainty in model calibration. Improved calibrations can be obtained if the recharge estimates are used in a ground-water-flow model calibrated to water-level data and known discharges for the area of interest.

\section{Sources of Data}

Sources of data used for developing and calibrating an INFIL3.0 model can be grouped into three general categories: (1) time series of daily climate data used to drive the waterbalance simulation through time; (2) GIS data including raster-based data sources such as the DEM and vector-based digital maps defining vegetation, soils, and geologic units; and (3) time series of streamflow data used for calibration. This section provides some examples of data sources for study areas in the United States.

Daily climate data for stations throughout the United States can be obtained online from the National Climatic Data Center (NCDC; http://www.ncdc.noaa.gov/oa/ncdc.html) for individual stations or packaged by region into more efficient databases through vendors. Because the data will not be in the format required for input to INFIL3.0, at least some preprocessing of the data will be needed. Other examples of sources for climate data include CIMIS, which maintains a Web site at www.cimis.gov (this is limited to locations in California), and Remote Automated Weather Stations (RAWS), which maintain a Web site at www.wrcc.gov. These online sources provide near-real-time data including precipitation and air temperature for hourly, daily, and monthly time intervals. CIMIS data include estimates of potential evapotranspiration (reference ETo), which can be compared to simulated potential evapotranspiration during model calibration. Regardless of the data source, the user should be aware of the quality of the data. Online data sources have the advantage of providing easy access to the most recent data, but quality checking for recent data may be minimal. In practice, at least some level of data screening should be incorporated into the preprocessing and reformatting of the climate data.

GIS data sources are essential for the efficient development of an INFIL3.0 model. The primary data source needed for the development of an INFIL3.0 model is the DEM. DEMs are widely available through a variety of sources. High-quality DEMs (having an approximate grid resolution of 10 to 30 meters) can be obtained online from http://gisdata. usgs.net/Website/Seamless/. Depending on study-area size, multiple panels may need to be downloaded and then merged into a single continuous raster grid or mosaic. Some degree of GIS processing will be required to develop the INFIL3.0 template grid; for example, clipping the DEM to the area of interest, reprojecting the area, and so forth.
Digital vegetation maps are available as statewide vector coverages from www.gap.gov. Many states also provide Web sites for obtaining statewide or county-wide vegetation maps. California provides several different statewide maps at www.csil.gov and http://frap.cdf.ca.gov. The California data were used to develop root-zone variables based on the mapped vegetation categories. A 30-meter raster-grid representation of forest canopy is also available at seamless.usgs.gov and was used in a recent study to develop estimates of vegetation cover (L.E. Flint, U.S. Geological Survey, written commun., April 2007).

Digital STATSGO soil maps are available by state at www.statsgo.gov. Documentation of STATSGO is available to help users in processing the STATSGO database (U.S. Department of Agriculture, 1994). Higher resolution, more spatially detailed SSURGO soil maps also are available at www.ssurgo.gov. The development of SSURGO map coverages is ongoing, however, and may not yet be available for a specific area of interest.

Digital geologic maps are available for most states as statewide coverages. The spatial resolution of the statewide maps may not be adequate for all study areas. For example, a recent study in California (L.E. Flint, U.S. Geological Survey, written commun., April 2007) used local-scale (1/24,000) geologic maps available for the study area to develop a spatially detailed representation of the surface geology, including both consolidated and unconsolidated units. The areal coverage of the unconsolidated units was used to define the location of thick soils and thus thick root zones.

Additional GIS data sources useful for model development include the National Hydrographic Dataset (NHD) available at http://nhd.usgs.gov/. The NHD data include low, medium, and high-resolution mapped streamlines and waterbodies. The NHD data are useful for defining the drainage network for the main stream channels and for defining important subbasins. For most locations in the United States, imperviousness can be obtained as a 30-meter raster coverage from http://gisdata.usgs.net/Website/Seamless/. The imperviousness can be used to help refine estimates of the permeability of surficial materials.

The preprocessing of the GIS data sources involves the application of several standard GIS procedures, such as reprojecting, merging, and clipping to the area of interest. After the DEM or base grid for the study area has been defined, vector-based GIS data (the vegetation, soils, and geology maps) are put in raster form and superimposed on the base grid, which assigns map identifiers to model cells.

A primary source of daily streamflow data for the United States is http://waterdata.usgs.gov/nwis/sw. Continuous records of daily mean discharge can be obtained for both current and historical streamflow-gaging sites. Real-time streamflow data can also be obtained for many locations. Quality flags are included with these data sets. 


\section{Input Instructions}

This section of the report describes instructions for preparing the data-input files required for an INFIL3.0 simulation. The input files are grouped into three types: control files, basin/watershed-characteristics files, and climate data files. In the descriptions that follow, variables used in mathematical equations are written in italicized upper- and lower-case plain text, whereas variables used in the computer program are written in lower-case bold text. Filenames are written in italics.

\section{Control Files}

Two control files must be prepared prior to an INFIL3.0 simulation. These files are called the Batch-Control File and the Simulation-Control File, and are described in detail below.

\section{Batch-Control File}

The Batch-Control File specifies the total number of INFIL3.0 simulations that will be done in sequence (that is, as a batch run) and the name of the Simulation-Control File for each simulation. The name of the Batch-Control File must be specified as infil3.ctl. Upon execution, INFIL3.0 will search for the file infil3.ctl and sequentially run each specified simulation. When simulating an upstream and downstream sequence of subbasins as part of a drainage network, the upstream subbasins must be listed above the downstream subbasins in the infil3.ctl file. The infil3.ctl file consists of the following input items:

1. header

2. nruns

3. The following record is read for each of nruns: runfile

Explanation of the variables:

header - is a character heading (character format A, maximum of 250 characters) used to identify the set of runs.

nruns - is an integer variable equal to the total number of simulations that will be made in the batch run. A maximum of 100 simulations can be specified in a batch run.

runfile - is a character variable (30 characters) that identifies the name of the Simulation-Control File associated with each simulation.

\section{Simulation-Control File}

A Simulation-Control File must be prepared for each simulation specified in the Batch-Control File. This file specifies several model-input variables, including the simulation time period and the names of most data-input and model-output files. The name of each Simulation-Control File is specified by variable runfile in the Batch-Control File.

Table 1-1 in appendix 1 lists the input variables that must be specified in each Simulation-Control File; figure 6 shows a sample Simulation-Control File. Additional information for some of the variables shown in table 1-1 follows:

irout-Flag that specifies the type of flow routing to be simulated. If irout is set to 0 , surface-water run-on is not allowed to infiltrate back into the root zone.

petadj-An empirical adjustment factor to the calculated potential evapotranspiration to account for cloud cover (precipitation). A value of about 0.16 has been used in previous modeling studies (Hevesi and others, 2003).

isksval-Flag that specifies whether soil saturated vertical hydraulic conductivity will be a constant value. If isksval is set to a value other than 0 , then a constant value of soil saturated vertical hydraulic conductivity will be set by variable sksval, and variable soilks in the Soil-Properties File will be ignored.

iimbval—Flag that specifies whether bedrock saturated and unsaturated hydraulic conductivities will be a constant value. If iimbval is set to a value other than 0 , constant bedrock hydraulic conductivities will be set by variable imbval, and variables imbibe and imbibe 2 in the Bedrock-Properties File will be ignored.

upgeoinp-Name of file containing upstream cellcode identifiers for cells contributing inflow. This file has the same format as the Geospatial Watershed-Characteristics File for each upstream basin.

barsoil1, rocket1, soilet1-Parameter $\beta$ (beta) in the modified Priestley-Taylor equation used for defining evaporation or plant transpiration from bare soil, rock matrix, and soil layers. A value of -10 for these three variables has been used in previous investigations (Flint and Childs, 1987; Hevesi and others, 2003).

barsoil2, rocket2, soilet2-Parameter $\alpha$ (alpha) in the modified Priestley-Taylor equation used for defining evaporation or plant transpiration from bare soil, rock matrix, and soil layers. A value of 1.04 has been used for barsoil2 and of 1.50 for rocket 2 and soilet 2 in previous investigations (Flint and Childs, 1987; Hevesi and others, 2003).

barsoilf-An adjustment factor that can be used to modify the value of barsoil1 for layer 2 of the model. A value of 1.0 causes the barsoil1 value for layers 1 and 2 of the model to be the same and has been used in previous investigations.

hstep-Time-step length used for calculating total daily evapotranspiration. HSTEP can range from 1.0 to 4.0 and values of either 1.0 or 2.0 are recommended. 


\section{Basin-Characteristics Files}

Several basin-characteristics files and an optional file named by variable restartfile are needed for an INFIL3.0 simulation. These files are: (1) Geospatial WatershedCharacteristics File, (2) Upstream Sources-of-Inflow Files, (3) Soil-Properties File, (4) Bedrock-Properties File, and (5) Vegetation-Properties File.

\section{Geospatial Watershed-Characteristics File}

Spatially distributed watershed characteristics for each grid cell of a model are specified in the Geospatial WatershedCharacteristics File. The name of the file is specified by the variable infile, which is defined in the Simulation-Control File (table 1-1). INFIL3.0 calculations in the surface-waterflow routing algorithm are based on the assumption that grid cells have been entered in an upstream to downstream order. Input variables associated with the upstream and downstream ordering are the upstream-cell identifier locid and the downstream-cell identifier iwat. Typically, the value of locid for the first cell entered will be 1 , and each successive value of locid will be increased by 1 .

Information for a maximum of 60,005 grid cells and 3,350 row or column grid indices can be specified for each simulation in the current version of INFIL3.0.

The file consists of the following input items:

\section{1. header}

2. The following free-format record is read for each grid cell:

\begin{tabular}{lllll} 
cellcode & easting & northing & lat & \multicolumn{1}{c}{ lon } \\
row & col & elev & sl asp \\
locid & iwat & upcells & soiltype \\
depth & rocktype & vegtype & skyview \\
ridge(36) & & & &
\end{tabular}

Explanation of the variables:

\section{$\underline{\text { Record } 1}$}

header - is a character heading (character format A, maximum of 250 characters) for the file, and is not printed to an output file.

\section{$\underline{\text { Record } 2}$}

cellcode - is an integer variable equal to the grid-cell (node) number. A maximum of 60,005 grid cells may be defined.

easting - is the east-west coordinate of the centroid of the grid cell, in meters (real variable).

northing - is the north-south coordinate of the centroid of the grid cell, in meters (real variable). lat — is the latitude of the centroid of the grid cell (real variable).

lon-is the longitude of the centroid of the grid cell (real variable).

row-is the row assignment of the grid cell (integer variable).

col—is the column assignment of the grid cell (integer variable).

elev-is the land-surface elevation of the centroid of the grid cell, in meters (real variable).

sl-is the land-surface slope of the centroid of the grid cell, degrees (real variable).

asp-is the land-surface aspect of the centroid of the grid cell, degrees azimuth relative to north (real variable).

locid-is an integer variable equal to the sequential number of the grid cell in the upstream-to-downstream ordering. Grid cells must be numbered incrementally from 1 for the first gridcell entry to the total number of grid cells in the modeled area for the last grid-cell entry.

iwat - is an integer variable equal to the downstream location identifier (variable locid) to which runoff is directed from the current cell. A value of iwat $=-3$ identifies the outflow cell of the basin, which is actually part of the downstream basin; a cell with iwat $=-3$, however, is excluded from the massbalance calculations for the basin being simulated.

upcells - is the total number of cells upstream to the current grid cell (and is used for streamflow routing) (real variable).

soiltype - is an integer code for the soil type in the grid cell. The value specified must be one of the soil types identified by variable soilid in the Soil-Properties File.

depth-is the total soil depth for the grid cell (not including bedrock depth), in meters (real variable).

rocktype - is an integer code for the bedrock type in the grid cell. The value specified must be one of the bedrock types identified by variable rockid in the Bedrock-Properties File.

vegtype - is an integer code for the vegetation type in the grid cell. The value specified must be one of the vegetation types identified by variable vegmap in the VegetationProperties File.

skyview - is total fraction of viewable sky, as fraction of hemisphere (dimensionless) (real variable).

ridge(36) — are the 36 blocking ridge angles (real variable). 
Figure 6. Simulation-Control File for sample problem.

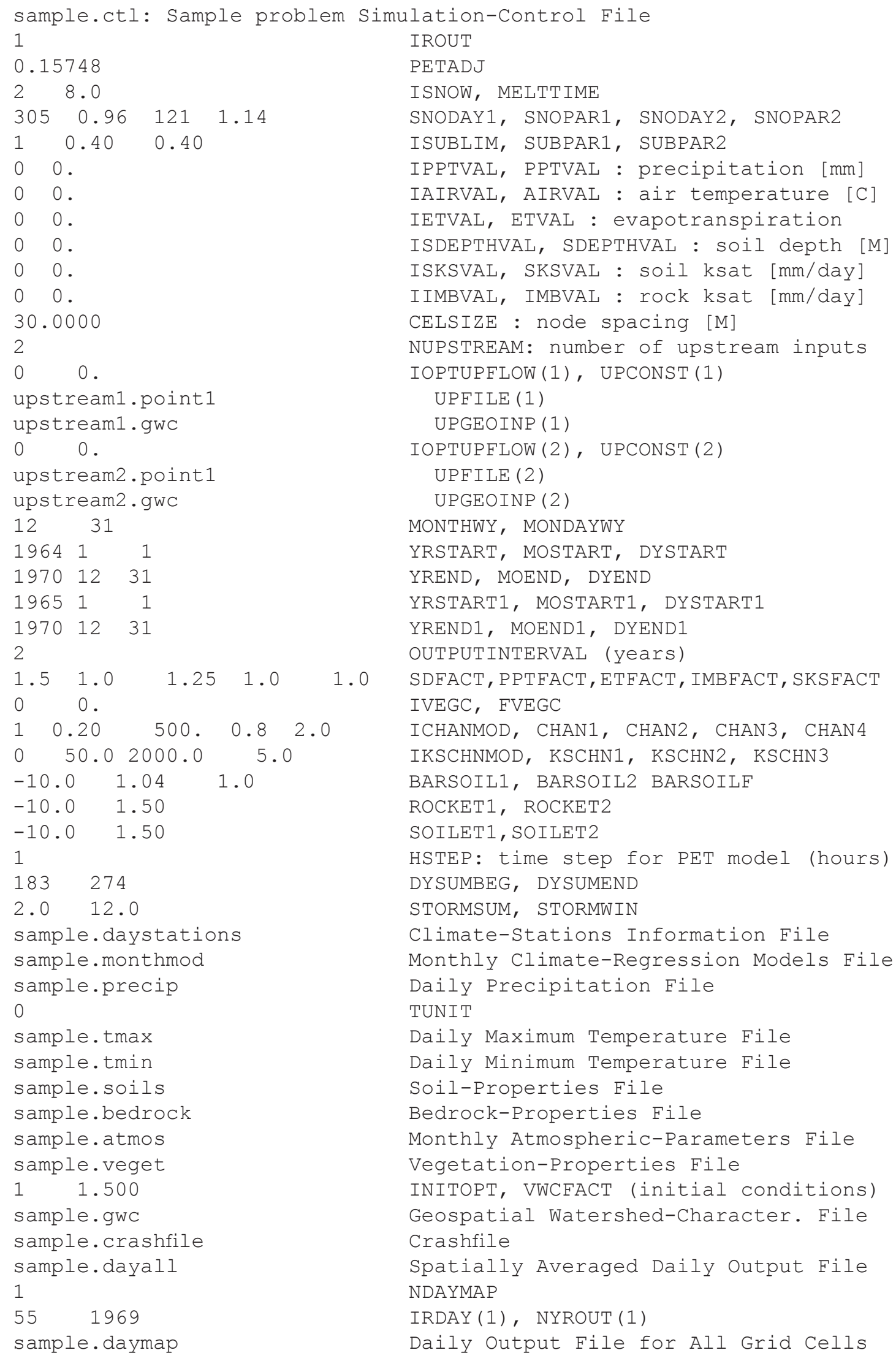




\section{Upstream Sources-of-Inflow Files}

Two files are needed for each upstream basin when simulating upstream surface-water inflows to a modeled area (that is, when variable nupstream, which is defined in the Simulation-Control File is greater than 0). The first is named by variable upgeoinp, which has the same format as the Geospatial Watershed-Characteristics File described in the previous section; therefore, the Geospatial WatershedCharacteristics File for each upstream basin can be used for upgeoinp. Although INFIL3.0 reads the entire contents of each upgeoinp file, the only value from each file that is used is the last value specified for variable cellcode. The last value of cellcode must be the same as the last value of cellcode for each of the other upstream basins and is equal to the cellcode of the grid cell that receives the upstream flow in the simulated basin. Surface-water inflows from a maximum of five upstream tributary subbasins can be simulated.

The second file that is required for each upstream basin is named by variable upfile. This file is a pointfile(1) output file generated for each upstream cell that contributes flow to a modeled area. Therefore, the user does not need to create this file but needs to have the name of an upfile for each upstream basin specified in the Simulation-Control File. (See the section "Daily Output Files for Specific Grid Locations" for a description of the contents of pointfile(1).)

\section{Soil-Properties File}

Information about the soils of the watershed is read from the Soil-Properties File, which is specified by variable soilprop in the Simulation-Control File. If the user assigns a value other than 0 to isksval in the Simulation-Control File, then a constant value equal to sksval, specified in the Simulation-Control File, is used for the soil saturated vertical hydraulic conductivity, and the value of soilks entered below will be ignored. Note, however, that the user must enter a value for soilks in the Soil-Properties File, even if it is ignored.

The Soil-Properties File consists of the following input items:

1. head1

2. nsoilid

3-4. head2-two records.

5. The following record is read nsoilid times for each type of soil. Each record should have the following format:

soilid soilmu soilporo fieldcap soilresid soilb soilks Explanation of the variables:

\section{$\underline{\text { Record } 1}$}

head1 - is a character heading (character format A, maximum of 250 characters); the heading is not printed to an output file.

\section{Record 2}

nsoilid-is an integer variable equal to the total number of soil types to be entered. A maximum of 800 soil types may be specified in the current version of INFIL3.0.

\section{Records 3-4}

head2 - are two lines of character headings (character format A, maximum of 250 characters); the headings are not printed to an output file.

\section{$\underline{\text { Record } 5}$}

soilid - is an integer variable used to identify the soil-type number (integer format I6).

soilmu — is the name of the soil type (character format A10).

soilporo - is the soil porosity, dimensionless (real format F8.4).

fieldcap - is the soil field capacity, dimensionless (real format F8.4).

soilresid - is the residual soil-water content for plant transpiration, which is also referred to as the wilting point, dimensionless (real format F8.4).

soilb-is the soil-drainage-function coefficient, dimensionless (real format F7.3).

soilks - is the soil saturated vertical hydraulic conductivity, in millimeters per day (real format F8.1).

\section{Bedrock-Properties File}

Information about the bedrock properties of the watershed is read from the Bedrock-Properties File, which is specified by variable rockprop, which is defined in the Simulation-Control File. If the user assigns a value other than 0 to iimbval in the Simulation-Control File, then a constant value equal to imbval, specified in the Simulation-Control File, will be used for both the effective unsaturated and saturated bedrock hydraulic conductivities, and the values of imbibe and imbibe 2 entered below will be ignored. Note, however, that the user must enter values for imbibe and imbibe 2 in the Bedrock-Properties File, even if they are ignored.

The Bedrock-Properties File consists of the following input items:

\section{1. header}

2. header nrockid

3-6. header-four records.

7. The following record is read nrockid times for each bedrock type. Each record should have the following format: 
rockid rockname2 rockporo imbibe imbibe2

Explanation of the variables:

\section{$\underline{\text { Record } 1}$}

header - is a character heading (character format A, maximum of 250 characters); the heading is not printed to an output file.

\section{$\underline{\text { Record } 2}$}

header-is a fixed-format 5-character text identifier.

nrockid - is a fixed-format integer variable equal to the total number of bedrock types to be entered. A maximum of 800 bedrock types may be specified in the current version of INFIL3.0.

\section{$\underline{\text { Records 3-6 }}$}

header - are four lines of character headings (character format A, maximum of 250 characters); the headings are not printed to an output file.

\section{$\underline{\text { Record } 7}$}

rockid - is an integer variable used to identify the bedrocktype number (integer format I6).

rockname2 - is the bedrock-type descriptor (character format A52).

rockporo - is the effective root-zone porosity (storage capacity) for the bedrock layer, dimensionless (real format F8.3).

imbibe-is the effective unsaturated vertical hydraulic conductivity for the bedrock layer (used to define a lowerbedrock vertical hydraulic conductivity), in millimeters per day (exponential format E10.1).

imbibe 2 - is the effective saturated vertical hydraulic conductivity for the bedrock layer (used to define an upperbedrock and deep-alluvium vertical hydraulic conductivity), in millimeters per day (exponential format E10.1).

\section{Vegetation-Properties File}

Information about the vegetation of the watershed is read from the Vegetation-Properties File, which is specified by variable vegprop defined in the Simulation-Control File. If the user assigns a value other than 0 to ivegc in the SimulationControl File, then a constant value equal to fvegc, specified in the Simulation-Control File, will be used for the vegetationcover variables vegcover0 and vegcover(6), and the values of vegcover0 and vegcover(6) entered below will be ignored. Note, however, that the user must enter values for vegcover0 and vegcover(6) in the Vegetation-Properties File, even if they are ignored.
The Vegetation-Properties File consists of the following input items:

1-4. header-four records

5. The following record is read for each vegetation type. A maximum of 500 vegetation types may be specified. The user does not need to specify the total number of vegetation types; INFIL3.0 will read each record until the last record has been read. Each record should have the following format:

$\begin{array}{cccc}\text { vegname1 } & \text { vegmap } & \text { vegcode } & \text { vegcover0 } \\ \text { vegname2 } & \text { vegcover(6) } & \text { rzdpth(6) } & \text { rzdpthf } \\ \text { Explanation of the variables: } & & \end{array}$

$\underline{\text { Records } 1-4}$

header-are four lines of character headings (character format $\mathrm{A}$, maximum of 250 characters); the headings are not printed to an output file.

\section{$\underline{\text { Record } 5}$}

vegname 1 - is the name of the vegetation type (character format A28).

vegmap - is a vegetation-type map-unit code. The values of vegmap must lie in the range $-10,000$ to 100,000 in the current version of INFIL3.0 (integer format I8).

vegcode - is a vegetation-code number (integer format I8).

vegcover 0 - is the percentage of land surface covered by vegetation (complementary value to the percent bare-soil cover) (real format F8.0).

vegname2 - is a second name for the vegetation class (character format A30).

vegcover(6) - is the percentage of root density for each of the six layers of the model. Six values are entered, each in F8.0 real format.

$\operatorname{rzdpth}(6)$ - are the root-zone depths from land surface for layers 1 through 5 and the root-zone thickness for layer 6 , in meters. Six values are entered, each in F8.0 real format.

rzdpthf - is the root-zone depth factor used in soil-layerthickness determinations (real format F8.0).

\section{Water-Budget Components for a Simulation Restart (Restart File)}

If a user sets initopt $=3$, then the initial soil-water contents for each layer at each cell are read from the file specified by variable restartfile in the Simulation-Control File. The user also must specify the day number (variable ndayscrash) of the last successful day of the simulation for 
which the data read from the file named by variable restartfile apply. The format of restartfile is exactly the same as that of crashfile, which also specifies a filename in the SimulationControl File. The contents of crashfile are described in detail in the "Output Files" section of this report [see subsection "Daily and Cumulative Output File for All Grid Cells for the Last Successful Day of a Simulation (Crashfile)"].

\section{Climate Data Files}

Several climate-data files are needed for an INFIL3.0 simulation. These are: (1) Climate-Stations Information File, (2) Monthly Climate-Regression Models File, (3) Monthly Atmospheric-Parameters File, and (4) Daily Climate Files (precipitation and maximum and minimum air temperatures).

\section{Climate-Stations Information File}

Information for each of the daily climate stations is read from the Climate-Stations Information File, which is specified by variable daystations defined in the SimulationControl File. The stations must be entered in the same order in which precipitation and temperature data are entered in the Daily Climate Files. A maximum of 250 climate stations can be specified for each simulation in the current version of INFIL3.0. The file consists of the following input items:

1. header

2. The following record is read for each climate station. The user does not need to enter the total number of stations for which data will be entered because the program will add the stations as they are entered and store the total as program variable nstations. Each record has the following format:

name statid eutm nutm statelev Explanation of the variables:

\section{$\underline{\text { Record } 1}$}

header - is a character heading (character format A, maximum of 250 characters).

\section{$\underline{\text { Record } 2}$}

name - is the name of the climate station (character format A28).

statid - is an integer-variable code for the climate station (integer format I9).

eutm-is the east-west coordinate of the climate station, in meters (real format F10.0).

nutm - is the north-south coordinate of the climate station, in meters (real format F11.0). statelev-is the elevation of the climate station, in meters (real format F8.0).

\section{Monthly Climate-Regression Models File}

Information about the models used to spatially distribute daily climate variables (precipitation and minimum and maximum air temperature) across the model domain is read from the Monthly Climate-Regression Models File, which is specified by variable monthmod in the Simulation-Control File. The file consists of the following input items:

\section{1. header}

2. The following record is read a total of 12 times, once for each month (free format):

$\begin{array}{lcccc}\text { imonth } & \text { pptmod } & \text { ppta } & \text { pptb } & \text { pptc } \\ \text { tmaxmod } & \text { tmaxa } & \text { tmaxb } & \text { tmaxc } & \text { tminmod } \\ \text { tmina } & \text { tminb } & \text { tminc } & & \\ \text { Explanation of the variables: }\end{array}$

$\underline{\text { Record } 1}$

header - is a character line (character format A, maximum of 250 characters).

$\underline{\text { Record } 2}$

imonth - is an integer variable for each month of the year, starting with 1 for January.

pptmod, tmaxmod, tminmod-are integer variables used to define the spatial-distribution model type for daily climate data: a value of 0 for pptmod, tmaxmod, or tminmod indicates that the inverse-distance-squared interpolation model is used; a value of 1 for pptmod, tmaxmod, or tminmod indicates that the linear-regression model is used (equation 3 in text); a value of 3 for pptmod, tmaxmod, or tminmod indicates that the quadratic-regression model is used (equation 4 in text).

ppta, pptb, pptc - are the regression-model coefficients (real variables) for the precipitation-elevation model for each month imonth. Values must be specified for all three variables, even if the linear model is used; a value of 0.0 can be specified for pptc if the linear model is used.

tmaxa, tmaxb, tmaxc - are the regression-model coefficients (real variables) for the maximum air temperature-elevation model for each month imonth. Values must be specified for all three variables, even if the linear model is used; a value of 0.0 can be specified for tmaxc if the linear model is used.

tmina, tminb, tminc - are the regression-model coefficients (real variables) for the minimum air temperature-elevation model for each month imonth. Values must be specified for all three variables, even if the linear model is used; a value of 0.0 can be specified for tminc if the linear model is used. 


\section{Monthly Atmospheric-Parameters File}

Information about the monthly atmospheric variables is read from the Monthly Atmospheric-Parameters File, which is specified by variable atmosinput in the Simulation-Control File. Input variables specified in this file are derived from climate-monitoring stations across the United States with long periods of record. The file consists of the following input items:

1. header

2. The following record is read a total of 12 times, once for each month (free format):

imonth ozone wp beta csr pg

Explanation of the variables:

\section{Record 1}

header - are four lines of character headings (character format $\mathrm{A}$, maximum of 250 characters); the headings are not printed to an output file.

\section{$\underline{\text { Record } 2}$}

imonth—is the month number (integer format).

ozone - is ozone-layer thickness for month imonth, in centimeters (real format).

wp-is the precipitable water in the atmosphere for month imonth, in centimeters (real format).

beta-is the mean atmospheric turbidity for month imonth, dimensionless (real format).

csr-is the circumsolar radiation for month imonth, dimensionless (real format).

pg-is the surface reflectivity for month imonth, dimensionless (real format).

\section{Daily Climate Files-Precipitation and Maximum and Minimum Air Temperatures}

Daily precipitation and maximum and minimum air temperatures for each climate station are read from three separate files, whose names are specified by variables daypptinput, daytmaxinput, and daytmininput defined in the Simulation-Control File. Each of the three files must have data for the same sequence of dates. Also, the precipitation and temperature data for each station must be entered in the same order in which climate-station information are entered in the Climate-Stations Information File. For example, the first values entered for ppt, maxairt, and minairt (array locations $\operatorname{ppt}(1)$, maxairt(1), and minairt(1), respectively) in each of the precipitation and maximum and minimum air temperature files, respectively, must be for the first station listed in the
Climate-Stations Information File. Temperature data are assumed to have units of degrees Celsius; if the data are in degrees Fahrenheit, then the user must specify variable tunit equal to 1 in the Simulation-Control File.

A maximum of 40,000 days can be simulated in a single model run in the current version of INFIL3.0. The files have the following input structures:

Precipitation file:

1. header2

2. The following record is read for each day of the simulation. Each record uses free format.

dyn yr month monday yearday ppt(nstations)

Maximum air-temperature file:

1. header2

2. The following record is read for each day of the simulation. Each record uses free format.

dyn yr month monday yearday maxairt(nstations)

Minimum air-temperature file:

1. header2

2. The following record is read for each day of the simulation. Each record uses free format.

dyn yr month monday yearday minairt(nstations)

Explanation of the variables:

Record 1 for each file

header2 -is a character heading (character format A, maximum of 250 characters); the heading is not printed to an output file.

Record 2 for each file

dyn - is the sequential day number in the simulation (integer format).

$\mathbf{y r}$-is the calendar year (for example, 1900) (integer format).

month - is the calendar month of the year, starting with 1 for January (integer format).

monday - is the sequential day in the month (for example, 1 for the first day of January, 31 for the last day of January) (integer format).

yearday - is the sequential Julian day of the year (for example, 1 for first day of 1900, 365 for the last day of 1900) (integer format).

ppt(nstations) - is the daily precipitation at each climate station, in millimeters (real format). 
maxairt(nstations) — is the daily maximum air temperature at each climate station, in degrees Celsius (real format).

minairt(nstations) - is the daily minimum air temperature at each climate station, in degrees Celsius (real format).

\section{Output Files}

INFIL3.0 generates several output files that provide simulation results. Each of these output files is described in detail below.

\section{Summary Output File}

The summary output file lists (1) the names of the input and output file names for the simulation, (2) a summary of the climate-input and watershed-characteristics data, (3) a summary of the simulation starting and ending dates and the simulation averaging period, (4) a summary of many of the water-budget components for all grid cells and for all days during a simulation averaging period, and (5) a summary of the root-zone mass balance for the simulation averaging period that is consistent with the water-budget terms given in equation 2. The simulation averaging period is defined by variables yrstart1, mostart1, and dystart1 for the start date of the averaging period and yrend1, moend1, and dyend1 for the end date of the averaging period; these variables are defined in the Simulation-Control File. These dates differ from the simulation starting and ending dates, which are defined by variables yrstart, mostart, and dystart for the simulation start date and yrend, moend, dyend for the simulation end date. A separate averaging period is included to allow the user the option of a model warm-up period, during which the system can respond to initial conditions. The name of the summary output file is specified by variable outfile in the SimulationControl File.

\section{Grid-Cell Properties Output File}

The grid-cell properties file, which is specified by variable spatialout in the Simulation-Control File, includes several pieces of information for each grid cell in the watershed-modeling domain. The information is written to the file prior to the actual INFIL3.0 simulations and therefore includes only input data or information calculated on the basis of specified input data. Definitions of the variables printed to the spatialout file are given in table 1-2 in appendix 1 .

\section{Daily Output Files for Each Grid Cell}

These files consist of water-budget components for each grid cell for specific days identified by the user by variables ndaymap (total number of daily map-output files) and irday and nyrout (the day and year, respectively, for each daily output file). Variable daymap is the name of each output file. Each of these variables is specified in the Simulation-Control File. A maximum of 100 days can be specified in a particular simulation. Definitions of the variables printed to each daymap file are given in table 1-3 in appendix 1 .

\section{Daily Output Files for Specific Grid Locations}

This file consists of water-budget components for each day of a simulation for grid cells identified by the user. INFIL3.0 automatically generates an output file for the last active grid cell in each model domain, and the user must use the variable pointfile(1) in the Simulation-Control File to specify the name of the file to which this output will be written. The user can then specify a maximum of an additional 19 grid cells for which output will be written by variables ipointfile (the number of additional output grid cells), xpoint and ypoint (the east-west and north-south coordinates of each additional grid cell, respectively), and pointfile (the name of the file for each additional grid cell). These variables are specified in the Simulation-Control File. Definitions of the variables printed to each pointfile are given in table 1-4 in appendix 1 .

\section{Annual and Average Annual Output Files for All Grid Cells}

The user has the option of printing total annual or average annual water-budget components for regular time intervals during the simulation for all grid. These output intervals are specified by a combination of variables defined in the Simulation-Control File. The first set of variables that must be specified are those that designate the simulation time period by which the annual and average annual calculations will be made. These are set using variables yrstart1, mostart1, and dystart1 for the start date of the period and yrend1, moend1, and dyend1 for the end date of the period. The month and day of the month that designate the interval for which annual and average annual calculations will be made are specified by variables monthwy and mondaywy. The output interval, in years, for which calculations will be made is specified by variable outputinterval. Output is then written to user-defined files every outputinterval years. Each of these files has the prefix designated by variable outyear1. If the user does not want to provide this type of output, outputinterval should be set to 0 . Definitions of the variables printed to each outyear 1 output file are given in table 1-5 in appendix 1 .

Two examples illustrate how this output works. In both examples, the simulation period is January 1, 1964 (specified by variables yrstart, mostart, and dystart) through December 31, 1970 (specified by variables yrend, moend, and dyend), and the simulation period during which annual and average annual calculations will be made is January 1, 1965 (specified by variables yrstart1, mostart1, and dystart1) through 
December 31, 1970 (specified by variables yrend1, moend1, and dyend1). For both examples, the date for which annual and average annual calculations will be made is December 31 (monthwy $=12$, mondaywy $=31$ ), and the prefix of the files to which output will be written (that is, variable outyear1) is sample. In the first example, the user wants to calculate annual totals for the water-budget components and therefore specifies outputinterval $=1$. In this case, annual water-budget totals will be written to six output files for the periods January 1 through December 31, 1965; January 1 through December 31, 1966; and so forth. The output files will have the names sample.0001, sample.0002, ... sample.0006. In the second example, the user wants to calculate average annual totals for the water-budget components every 2 years and therefore specifies outputinterval $=2$. In this case, average annual water-budget totals will be written to three output files for the periods January 1, 1965 through December 31, 1966; January 1, 1967 through December 31, 1968; and January 1, 1969 through December 31, 1970. The output files will have the names sample.0001, sample.0002, and sample.0003. Note that in both cases, if the averaging period started on a date other than January 1, the first averaging period would have been less than a full year (or 2 full years for the second example).

\section{Daily and Cumulative Output File for All Grid Cells for the Last Successful Day of a Simulation (Crash File)}

At the end of each successful simulation for December 31, several water-budget components are written to a file for all grid cells. This file is named by the variable crashfile and is defined in the Simulation-Control File. The contents of the file can then be used for a model restart. Depending on the day of a simulation crash (due to a power failure, for example), the maximum number of days that would need to be resimulated is 366 (if the crash occurred on the last day of a leap year). Definitions of the variables printed to crashfile are given in table 1-6 in appendix 1 .

\section{Spatially Averaged Daily Output File}

This file consists of spatially averaged water-budget components for all active grid cells for each day of a simulation. The active grid cells include all of the cells except the outflow cell of the basin (that is, the cell with variable iwat equal to -3). A single line of output is written for each day of a simulation and consists of water-budget components averaged over all of the active grid cells. The name of the file to which the output is written is specified by variable dayall in the Simulation-Control File. Definitions of the variables printed to dayall are given in table $1-7$ in appendix 1 .

\section{Monthly and Annual Output Files for All Grid Cells}

The user has the option of printing total monthly and total annual water-budget components for all active grid cells. Output for these options is written to files outmonth and outannual, respectively, which are defined in the SimulationControl File. Monthly output will be written for each month, but the first and last months may be based on fewer than a full month of days depending on the starting and ending dates of the simulation periods. Annual output will be written for simulation days between January 1 and month and day monthwy and mondaywy, respectively, which are defined in the Simulation-Control File. For example, if the user assigns monthwy a value of 12 and mondaywy a value of 31, total annual water-budget components will be added for each year starting on January 1 and ending on December 31 . The first and last annual totals may be based on fewer than a full year of days depending on the starting and ending dates of the simulation periods. Water-budget components are written to the output files for both the monthly and annual totals, and the definitions of the variables printed to each output file are given in table $1-8$ in appendix 1 .

\section{Average Annual Output File for All Grid Cells for a Specified Averaging Period}

The user has the option of printing average annual waterbudget components for all grid cells. The averaging period is defined by variables yrstart1, mostart1, and dystart1 for the start date of the period and yrend1, moend1, and dyend1 for the end date of the period. Output is written to the file defined by variable flxfile in the Simulation-Control File. Definitions of the variables printed to flxfile are given in table 1-9 in appendix 1 .

\section{Sample Problem}

A sample problem is provided to illustrate how INFIL3.0 can be applied to a field setting. The sample problem provides a brief description of the modeled area, an overview of model input and output files, and a discussion of some results of the multiyear simulation.

\section{Description of Basin}

The modeled area is representative of conditions in the Big Bear Lake area of south-central California, about 130 kilometers east-northeast of Los Angeles. Although basin characteristics and model inputs were selected on the basis of reported field conditions, the sample problem is a simplified abstraction of field conditions and is not intended to yield an accurate simulation of the actual hydrologic conditions. Model 
characteristics and input files are based on an ongoing study by the U.S. Geological Survey (L.E. Flint, U.S. Geological Survey, written commun., April 2007).

Hydrologic concerns within the study area center on overuse of the existing ground-water resources under climatic conditions such as drought. A primary goal of the study was to estimate the quantity, distribution, and source of recharge to the ground-water basin. This goal was addressed by the construction of a model of the study area by use of an earlier version of the INFIL code, because net-infiltration rates calculated by INFIL can be taken to be equivalent to recharge rates to an underlying water table.

The Big Bear Valley ground-water basin underlies Bear Valley and is bounded by crystalline rocks of the San Bernardino Mountains (L.E. Flint, U.S. Geological Survey, written commun., April 2007). The basin is predominantly underlain by alluvial deposits and older sedimentary deposits. Ground water in the basin is generally in the unconsolidated alluvial deposits on the lower slopes of the surrounding mountains and in the valley. The basin deposits consist of sands and gravels with interbedded clays. Precipitation as rain and snow provides the water available for recharge to the underlying ground-water basin. Average annual precipitation in the valley ranges from $900 \mathrm{~mm}$ on the western edge of the valley to $450 \mathrm{~mm}$ on the eastern edge of the valley. Ground-water levels within the basin vary in response to precipitation. In general, when precipitation quantities are in excess of average values, water levels rise, and when precipitation quantities are less than average values, water levels decline (L.E. Flint, U.S. Geological Survey, written commun., April 2007).

Big Bear Lake, in the western portion of the valley, is at the base of a north-facing slope at an elevation of approximately $2,073 \mathrm{~m}(6,800 \mathrm{ft})$. The surrounding mountains rise to approximately 2,377 to $2,621 \mathrm{~m}$ (7,800 to $8,600 \mathrm{ft}$ ) along the ridge to the south of the lake. Big Bear Lake is filled by runoff from creeks that drain the valley floor. Baldwin Lake, which is typically dry, lies in the northeastern portion of the valley.

\section{Construction of INFIL3.0 Model}

The area of the Big Bear Valley modeled by INFIL 3.0 was $186.5 \mathrm{~km}^{2}\left(72 \mathrm{mi}^{2}\right)$ and included 11 surfacewater drainage basins and 2 lakes. The modeled area was discretized into a base grid of square cells each having a length of $30 \mathrm{~m}(98.4 \mathrm{ft})$ on a side. The grid consisted of 1,279 rows and 1,875 columns. The 11 surface-water drainage basins and 2 lakes were further subdivided into a total of 40 simulation units, with 9 simulation units representing the Baldwin Lake drainage and 31 simulation units representing the Big Bear Lake drainage. Model subunits were based on surface-water drainage boundaries defined by a GIS computer package (ArcGIS and the Arc Hydro extension). The DEM that was used as part of the GIS basin delineations was modified on the basis of high-resolution hydrography data sets available from the U.S. Geological Survey National Hydrography Dataset (www.seamless.usgs.gov). The subdivision of the 11 surface- water drainage basins into smaller simulation units is not required for application of INFIL3.0, but was done to improve the efficiency of model operation and to allow for a more direct comparison of INFIL3.0 recharge estimates with those made for the drainage basins in previous studies of the area.

A simulation unit in the Baldwin Lake drainage system is used to illustrate the input and output files of an INFIL3.0 simulation. The simulation unit is referred to as the "sample" basin. Two upstream basins drain into the sample basin and therefore provide upstream flows to the sample basin; these basins are referred to as "upstream basin 1" and "upstream basin 2." The sample basin consists of a total of 2,357 active grid cells, with row numbers ranging from 460 through 522 and column numbers ranging from 1,300 to 1,378 . The total size of the simulated area is therefore $2.12 \mathrm{~km}^{2}$. The simulated areas of upstream basins 1 and 2 are 2.41 and $3.08 \mathrm{~km}^{2}$, respectively.

A total of six model layers was used to represent the root zone to account for differences in root density and root-zone water content as a function of depth. The upper five root-zone layers were used to represent the soil component of the root zone. For locations estimated as having thick soils underlain by unconsolidated deposits, the root zone had a maximum total thickness of $8 \mathrm{~m}$, as defined by the Vegetation-Properties File, and was discretized into five soil layers. Drainage from the root zone (net infiltration from layer 5) was a function of the water content of layer 5 and the estimated vertical hydraulic conductivity of the underlying material. For locations estimated as having thinner soils underlain by consolidated bedrock, the number and thickness of both the soil layers and the underlying bedrock layer (layer 6) was based on the estimated soil thickness. The thickness of the bedrock layer also was dependent on the vegetation type assigned to each grid cell, and was used to represent the extension of the root zone into bedrock (roots extending into fractures and weathered zones).

A summary of the input and output files for the sample problem is given in table 1 . The names of all input and output files except that of the Simulation-Control File are defined in the Simulation-Control File (fig. 6). The name of the Simulation-Control File is defined in the Batch-Control File (infil3.ctl). Most of the additional variables defined in the Simulation-Control File are described in more detail below.

The simulation period selected for the sample problem was January 1, 1964 through December 31, 1970. The period selected for averaging of model results, however, was selected to be the 6-year period January 1, 1965 through December 31, 1970, which allowed a 1-year period for model initialization (warm-up). An outputinterval of 2 years was specified, as well as a date of December 31 for reporting the average annual results (monthwy $=12$ and mondaywy $=31$ ); therefore, average annual results were printed to output files sample.0001, sample.0002, and sample.0003 for the periods January 1, 1965 through December 31, 1966; January 1, 1967 through December 31, 1968; and January 1, 1969 through December 31, 1970. 
Table 1. Names of input and output files for the sample problem.

\begin{tabular}{|c|c|}
\hline File type & File name \\
\hline \multicolumn{2}{|c|}{ Input files } \\
\hline Batch Control & infil3.ctl \\
\hline Simulation Control & sample.ctl \\
\hline $\begin{array}{l}\text { Geospatial Watershed } \\
\text { Characteristics }\end{array}$ & sample.gwc \\
\hline \multicolumn{2}{|l|}{ Upstream Basin 1} \\
\hline upgeoinp file & upstream1.gwc \\
\hline upfile & upstream1.point1 \\
\hline \multicolumn{2}{|l|}{ Upstream Basin 2} \\
\hline upgeoinp file & upstream2.gwc \\
\hline upfile & upstream2.point1 \\
\hline Soil Properties & sample.soils \\
\hline Bedrock Properties & sample.bedrock \\
\hline Vegetation Properties & sample.veget \\
\hline Climate-Station Information & sample.daystations \\
\hline $\begin{array}{l}\text { Monthly Climate-Regression } \\
\text { Models }\end{array}$ & sample.monthmod \\
\hline Monthly Atmospheric Parameters & sample.atmos \\
\hline Daily Precipitation & sample.precip \\
\hline Daily Maximum Air Temperature & sample.tmax \\
\hline Daily Minimum Air Temperature & sample.tmin \\
\hline \multicolumn{2}{|c|}{ Output files } \\
\hline Summary Output & sample.outfile \\
\hline Grid-Cell Properties & sample.spatialout \\
\hline Daily Output for all Grid Cells & sample.daymap \\
\hline $\begin{array}{l}\text { Daily Output for Specific Grid } \\
\text { Locations }\end{array}$ & $\begin{array}{l}\text { sample.point1, sample.point2, } \\
\text { sample.point3, sample. } \\
\text { point4, sample.point5, } \\
\text { sample.point6 }\end{array}$ \\
\hline $\begin{array}{l}\text { Annual and Average Annual } \\
\text { Output for all Grid Cells } \\
\text { (prefix is "sample") }\end{array}$ & $\begin{array}{l}\text { sample.0001, sample.0002, } \\
\text { sample. } 0003\end{array}$ \\
\hline Crash File & sample.crashfile \\
\hline Spatially Averaged Daily Output & sample.dayall \\
\hline $\begin{array}{l}\text { Monthly and Annual Output for } \\
\text { all Grid Cells }\end{array}$ & $\begin{array}{l}\text { sample.outmonth, sample. } \\
\text { outannual }\end{array}$ \\
\hline $\begin{array}{l}\text { Average Annual Output for all } \\
\text { Grid Cells During a Specified } \\
\text { Averaging Period }\end{array}$ & sample.flxfile \\
\hline
\end{tabular}

Although the simulation period for the sample problem was 1964 through 1970, the study on which this sample problem was based used a much longer simulation period of 79 years, extending from October 1, 1926 through September 30, 2005. Daily climate data for that extended period were obtained from the NCDC (EarthInfo, Inc., 2004) for a network of 35 climate stations in the southern California region. All climate stations had precipitation data, but only 14 had air-temperature data. The selection of the 35 climate stations was based on proximity to the study site, similarity of climate characteristics, and adequacy of record (only stations with 4 or more years of record were included in the network). The calculated spatial distribution of air temperature is a critical factor affecting the simulation of precipitation as snow, snowmelt, sublimation, and potential evapotranspiration.

Sample input files for the climate stations (file sample. daystations) and for the precipitation data (file sample.precip) are shown in figures 7 and 8 , respectively. The input format for the daily temperature data was similar to that for the daily precipitation data and is not shown. Average daily air temperature for the 1965 through 1970 averaging period was $8.7^{\circ} \mathrm{C}$, and average annual precipitation for the same period was $778 \mathrm{~mm}$.

Model coefficients for simulating snowmelt and sublimation were specified in the Simulation-Control File. For snowmelt, coefficients were based on those determined for the Sierra Nevada of California (Gray and Prowse, 1993; table 7.3.7), with snopar 1 equal to 0.96 and snopar 2 equal to 1.14 . The starting day for the timing of the early-spring snowmelt period (Julian day 305; snoday1) corresponds to November 1, whereas the starting day for the timing of the late-spring snowmelt (Julian day 121; snoday2) corresponds to May 1. Sublimation variables subpar1 and subpar2 were each estimated to be 0.40 and were not changed during model calibration.

The input data in the Monthly Atmospheric-Parameters File (fig. 9; file sample.atmos) is the same as that used for previous applications of earlier versions of the INFIL code to the southern California region (Hevesi and others, 2003; Nishikawa and others, 2004; Rewis and others, 2006). The monthly precipitation elevation, maximum air-temperature elevation, and minimum air-temperature elevation regression models for defining average monthly precipitation and maximum and minimum air temperature on the basis of elevation (fig. 10) were developed by using a method described in Rewis and others (2006) and data from a subset of 14 climate stations having 9 or more years of record and centered over the Big Bear study area.

Several variables in the Simulation-Control File relate to the simulation of evapotranspiration. The first is the empirical adjustment factor to the calculated potential evapotranspiration to account for cloud cover during precipitation (variable petadj). Previous modeling studies used a value of about 0.16 for petadj (Hevesi and others, 2003), which also was used in the Big Bear study. The time-step length for calculating total daily evapotranspiration in the POTEVAP subroutine 
Figure 7. Climate-Stations Information File for sample problem.

$\begin{array}{lllll}28 & 9 & 10 & 11 & 8 \\ \text { APPLE VALLEY } & 40244 & 480110.2 & 3819470.4 & 894.5 \\ \text { BEAUMONT } & 40606 & 502310.6 & 3754306.1 & 796.4 \\ \text { BEAUMONT PUMPING PLANT } & 40607 & 503075.8 & 3760304.8 & 929.9 \\ \text { BEAUMONT \#2 } & 40609 & 503059.4 & 3753873.9 & 792.4 \\ \text { BENNETT RANCH } & 40678 & 458524.7 & 3780731.1 & 563.9 \\ \text { BIG BEAR LAKE } & 40741 & 508849.2 & 3789237.1 & 2060.4 \\ \text { BIG BEAR LAKE DAM } & 40742 & 502357.4 & 3788922.8 & 2077.1 \\ \text { CABAZON } & 41250 & 520031.3 & 3752941.0 & 548.9 \\ \text { CAMP ANGELUS } & 41369 & 501816.1 & 3778699.4 & 1758.6 \\ \text { CRESTLINE } & 42162 & 472377.0 & 3789916.8 & 1484.9 \\ \text { FONTANA 5 N } & 43118 & 458532.8 & 3782571.7 & 601.0 \\ \text { HESPERIA } & 43935 & 472431.6 & 3808401.2 & 975.9 \\ \text { JOSHUA TREE } & 44405 & 563003.1 & 3777147.0 & 829.9 \\ \text { JOSHUA TREE 3 S } & 44407 & 563027.8 & 3773454.6 & 1064.0 \\ \text { KEE RANCH } & 44467 & 543014.5 & 3780738.0 & 1320.9 \\ \text { LAKE ARROWHEAD } & 44671 & 482661.3 & 3789526.2 & 1586.4 \\ \text { LUCERNE VALLEY } & 45182 & 504592.9 & 3812054.1 & 903.1 \\ \text { LYTLE CREEK PH } & 45215 & 458541.0 & 3784423.5 & 686.1 \\ \text { LYTLE CREEK R S } & 45218 & 456644.2 & 3788678.9 & 832.1 \\ \text { MILL CREEK 2 } & 45629 & 496927.8 & 3771392.7 & 897.0 \\ \text { MILL CREEK INTAKE } & 45632 & 505867.0 & 3772292.1 & 1507.2 \\ \text { MORONGO VALLEY } & 45863 & 538466.5 & 3765926.5 & 780.9 \\ \text { PALM SPRINGS } & 46635 & 545369.7 & 3743137.9 & 129.5 \\ \text { RAYWOOD FLATS } & 47279 & 516917.4 & 3767715.1 & 2155.8 \\ \text { REDLANDS } & 47306 & 482520.1 & 3768026.5 & 401.7 \\ \text { RUNNING SPRINGS 1 E } & 47600 & 492040.5 & 3785078.2 & 1818.0 \\ \text { SAN BERNARDINO F S 226 } & 47723 & 476589.9 & 3777087.3 & 347.5 \\ \text { SANTA ANA RIVER P H 3 } & 47891 & 490213.6 & 3773437.5 & 604.7 \\ \text { SANTA ANA RIVER PH 1 } & 47894 & 493850.0 & 3776938.2 & 844.9 \\ \text { SEVEN OAKS } & 48105 & 504607.5 & 3782481.4 & 1548.9 \\ \text { SOUTH FORK CABIN } & 48390 & 516914.1 & 3769566.7 & 2171.9 \\ \text { SQUIRREL INN 1 } & 48476 & 476976.3 & 3788052.6 & 1598.0 \\ \text { SQUIRREL INN 2 } & 48479 & 478514.3 & 3788048.9 & 1731.8 \\ \text { TWENTYNINE PALMS } & 49099 & 588808.0 & 3776778.4 & 602.0 \\ \text { VICTORVILLE PUMP PLANT } & 49325 & 471938.3 & 3821520.8 & 871.1\end{array}$


Figure 8. Part of Daily Precipitation File for sample problem.

[Note that data are shown only for the first 5 climate stations; data are not shown for the remaining 30 climate stations; -999.99 indicates missing data; precipitation values are in millimeters per day]

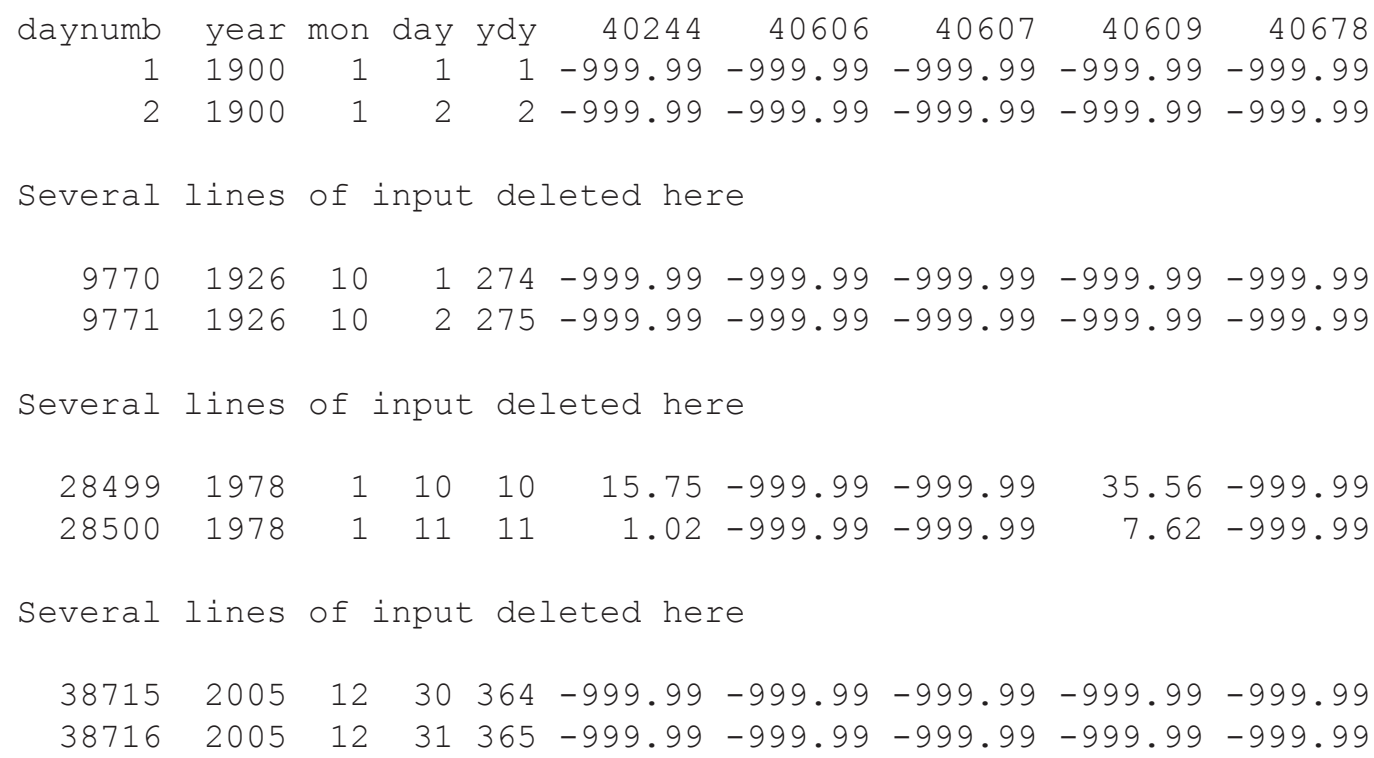

Figure 9. Monthly Atmospheric-Parameters File for sample problem.

\begin{tabular}{|c|c|c|c|c|c|}
\hline month & ozone & wp & beta & $\operatorname{csr}$ & $\mathrm{pg}$ \\
\hline 1 & 0.29 & 1.000 & 0.075 & 0.85 & 0.24 \\
\hline 2 & 0.31 & 1.000 & 0.075 & 0.85 & 0.24 \\
\hline 3 & 0.32 & 1.050 & 0.075 & 0.85 & 0.24 \\
\hline 4 & 0.33 & 1.100 & 0.085 & 0.85 & 0.24 \\
\hline 5 & 0.33 & 1.500 & 0.085 & 0.74 & 0.24 \\
\hline 6 & 0.32 & 1.800 & 0.090 & 0.74 & 0.24 \\
\hline 7 & 0.30 & 2.200 & 0.090 & 0.57 & 0.24 \\
\hline 8 & 0.29 & 2.440 & 0.084 & 0.57 & 0.24 \\
\hline 9 & 0.28 & 2.000 & 0.077 & 0.66 & 0.24 \\
\hline 10 & 0.27 & 1.400 & 0.075 & 0.74 & 0.24 \\
\hline 11 & 0.27 & 1.050 & 0.075 & 0.90 & 0.24 \\
\hline 2 & 0.28 & 0.950 & 0.075 & 0.90 & 0.24 \\
\hline
\end{tabular}


Figure 10. Monthly Climate-Regression Models File for sample problem.

$\begin{array}{ccllccccccccc}\text { month } & \text { pptmod } & \text { ppta } & \text { pptb } & \text { pptc tmaxmod } & \text { tmaxa } & \text { tmaxb tmaxc tminmod tmina } & \text { tminb tminc } \\ 1 & 1 & 5.29 \mathrm{E}-02 & 76.23 & 0 & 1 & -7.00 \mathrm{E}-03 & 21.08 & 0 & 1 & -5.30 \mathrm{E}-03 & 6.35 & 0 \\ 2 & 1 & 4.71 \mathrm{E}-02 & 63.34 & 0 & 1 & -7.20 \mathrm{E}-03 & 22.62 & 0 & 1 & -5.50 \mathrm{E}-03 & 7.43 & 0 \\ 3 & 1 & 3.04 \mathrm{E}-02 & 57.45 & 0 & 1 & -7.10 \mathrm{E}-03 & 23.58 & 0 & 1 & -5.60 \mathrm{E}-03 & 8.28 & 0 \\ 4 & 1 & 2.83 \mathrm{E}-02 & 26.17 & 0 & 1 & -6.60 \mathrm{E}-03 & 26.19 & 0 & 1 & -5.10 \mathrm{E}-03 & 9.83 & 0 \\ 5 & 1 & 9.80 \mathrm{E}-03 & 7.86 & 0 & 1 & -5.30 \mathrm{E}-03 & 28.29 & 0 & 1 & -4.40 \mathrm{E}-03 & 11.89 & 0 \\ 6 & 1 & 5.00 \mathrm{E}-04 & 2.21 & 0 & 1 & -4.70 \mathrm{E}-03 & 32.17 & 0 & 1 & -3.40 \mathrm{E}-03 & 13.86 & 0 \\ 7 & 1 & 4.20 \mathrm{E}-03 & 0.00 & 0 & 1 & -5.10 \mathrm{E}-03 & 36.76 & 0 & 1 & -2.40 \mathrm{E}-03 & 16.41 & 0 \\ 8 & 1 & 4.90 \mathrm{E}-03 & 0.94 & 0 & 1 & -5.20 \mathrm{E}-03 & 36.74 & 0 & 1 & -2.80 \mathrm{E}-03 & 16.88 & 0 \\ 9 & 1 & 8.10 \mathrm{E}-03 & 5.25 & 0 & 1 & -5.90 \mathrm{E}-03 & 35.06 & 0 & 1 & -3.90 \mathrm{E}-03 & 15.98 & 0 \\ 10 & 1 & 6.80 \mathrm{E}-03 & 9.63 & 0 & 1 & -6.30 \mathrm{E}-03 & 30.53 & 0 & 1 & -4.30 \mathrm{E}-03 & 12.61 & 0 \\ 11 & 1 & 3.29 \mathrm{E}-02 & 33.57 & 0 & 1 & -7.00 \mathrm{E}-03 & 25.63 & 0 & 1 & -4.80 \mathrm{E}-03 & 8.91 & 0 \\ 12 & 1 & 4.20 \mathrm{E}-02 & 44.49 & 0 & 1 & -7.10 \mathrm{E}-03 & 22.06 & 0 & 1 & -4.90 \mathrm{E}-03 & 6.44 & 0\end{array}$

Figure 11. Geospatial Watershed-Characteristics File for sample problem.

[Note that 29 of the blocking-ridge angles have been deleted for each entry, and that the record of input data for each grid cell wraps onto two lines of text.]

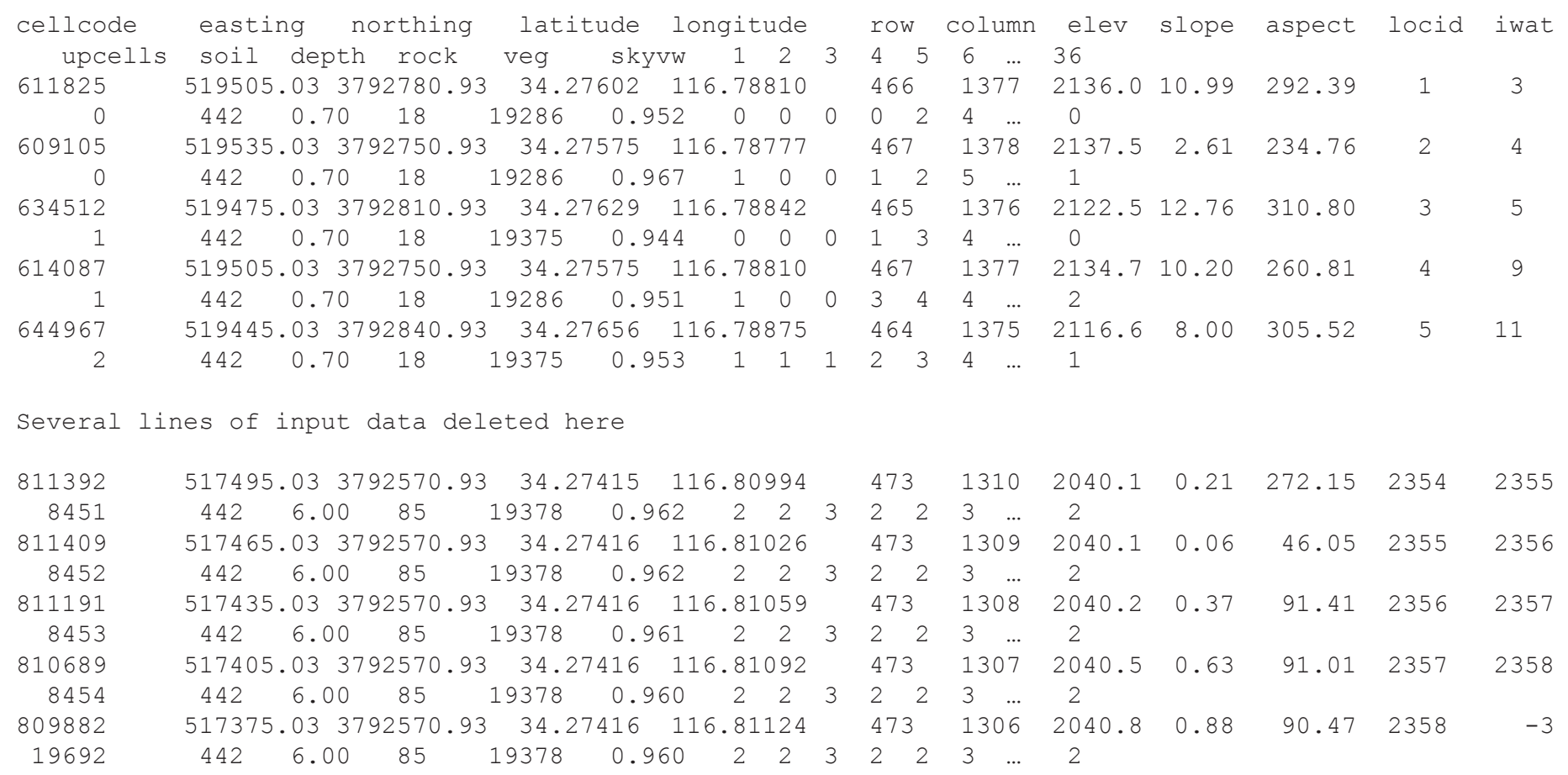


(variable hstep) was set to a value of 1 hour. Variables barsoil1, rocket1, and soilet1 - the $\beta$ variables in the modified Priestley-Taylor equation for defining evaporation or plant transpiration from bare soil, rock matrix, and soil layerswere each set to a value of -10 based on the previous work of Flint and Childs (1987) and Hevesi and others (2003). Variable barsoil2 - the $\alpha$ parameter in the modified Priestley-Taylor equation for defining evaporation as a function of bare-soil water content and potential evapotranspiration-was set to a value of 1.04, which is a standard value used for bare-soil surfaces (Hevesi and others, 2003). Variables rocket 2 and soilet2 - the $\alpha$ variables in the modified Priestley-Taylor equation for defining transpiration as a function of rock-matrix and soil-water content and potential evapotranspirationwere each set to a value of 1.50 based on Hevesi and others (2003). During model calibration, an adjustment factor to the evapotranspiration calculations was specified by setting variable etfact equal to 1.25 in the Simulation-Control File.

Soil-water initial conditions for most of the water-balance terms in the INFIL3.0 simulation - the product of the residual water content of the soil, the thickness of the soil layer, and a multiplication factor-were set by specifying a value of 1 for initopt in the Simulation-Control File. The multiplication factor, variable vwcfact, was set to 1.5 in the SimulationControl File. Residual water contents of the soils were specified in the Soils-Properties File (file sample.soils).

The topographic variables are used to estimate potential evapotranspiration, to distribute daily air temperature spatially over the drainage basin, and to route streamflow. The topographic variables for each model cell included location, elevation, aspect, slope, a set of 36 blocking-ridge angles (used to simulate the fraction of sky viewed for each grid cell in the calculation of incoming solar radiation), and streamflow-routing variables (location of adjacent upstream cell, location of adjacent downstream cell, and number of upstream cells). Many of these variables are specified in the Geospatial Watershed-Characteristics File; the Geospatial WatershedCharacteristics File (file sample.gwc) for the sample problem is given in figure 11.

The topographic variables in the Geospatial WatershedCharacteristics File were developed from standard GIS applications. The flow-routing variables were defined by a modified DEM and the D-8 routing algorithm available with GIS. The skyview and blocking-ridge angles were calculated by a FORTRAN preprocessing routine, SKYVIEW, modified from an original program developed by Flint and Childs (1987). The SKYVIEW routine approximates the 36 10-degreeazimuth sectors for the blocking-ridge angles by using the exact row-column position of surrounding grid cells relative to the central grid cell from which the blocking-ridge angles are being defined. For each of the 36 approximate 10-degree sectors, the blocking angle is defined by the horizontal distance and difference in elevation between the central grid cell and the potential blocking-ridge cell. The routine is applied to surrounding grid cells at successively greater distances from the central cell by increasing the number of rows and col- umns applied to the search neighborhood, up to a user-defined maximum search distance (for the Big Bear study, a maximum search distance of 5,000 $\mathrm{m}$ was applied). For each of the 36 approximate 10-degree sectors, the maximum blocking angle within the search neighborhood is used to define the blockingridge angle for the central cell. The 36 blocking-ridge angles are added and this fraction of the hemisphere is subtracted from the total hemisphere area to calculate the SKYVIEW factor, expressed as a fraction of the total hemisphere area (a flatgrid DEM would result in SKYVIEW values of 1.0, whereas a grid at the base of a deep canyon might have a SKYVIEW value of 0.5 or less).

Soil variables were estimated for each model cell by using the State Soil Geographic Database (STATSGO) digital map and associated attribute tables (U.S. Department of Agriculture, 1994). The soil variables were estimated by applying a preprocessing routine, STATSGO34, developed for the application of an earlier version of the INFIL code to the Death Valley region (Hevesi and others, 2003). The STATSGO34 routine uses soil-texture data from the STATSGO database to estimate field capacity, wiltingpoint water content, and the drainage-function coefficient (variable soilb in the Soil-Properties File). Estimates of porosity, saturated vertical hydraulic conductivity, and total soil thickness also are calculated from data available in the STATSGO database. The estimated values for all soil variables are approximate values based on a weighted-averaging method because the STATSGO database generally includes several soil components, each with several soil layers, for each mapped soil unit, or soil Map Unit Identifier (MUID). Soil-layer thickness and relative areas of the soil components within each MUID are provided in the STATSGO database, and these values are used to calculate the weighted averages for the soil variables associated with the different MUIDs. A more detailed discussion of the STATSGO34 preprocessing routine is given in Hevesi and others (2003). A total of 21 STATSGO soil types (or MUIDs) were identified within the Big Bear watershed (fig. 12). The average depth of the soil zone within the watershed is $6.06 \mathrm{~m}$. During model calibration, initial soil depths estimated from the STATSGO database were increased by a factor of 1.5 by using variable sdfact in the SimulationControl File. This adjustment to the STATSGO soil thickness is consistent with a similar model applied to a nearby study area in the San Gorgonio Pass area (Rewis and others, 2006).

Spatially distributed bedrock and deep-soil variables that are needed for the bedrock (model layer 6) and deepalluvium areas (soil depth of $8 \mathrm{~m}$ or greater), respectively, are root-zone porosity and vertical hydraulic conductivity (fig. 13; file sample.bedrock). The geologic units for the study area were identified on the basis of surficial geologic maps, and deep soil was identified on the basis of Quaternary alluvium geologic classifications. These units were assigned an initial value of root-zone porosity and vertical hydraulic conductivity consistent with those assigned to equivalent geologic units in the Death Valley region by Hevesi and others (2003). The original estimates of root-zone porosity were not 
Figure 12. Soil-Properties File for sample problem.

\begin{tabular}{lllllll} 
Sample problem soil properties input \\
21 & \multicolumn{7}{l}{} & & & \\
6 & 10 & 8 & 8 & 8 & 8 & \multicolumn{1}{l}{8} \\
mapid & MUID & POR & FC & WP & B & ksat01 \\
425 & CA671 & 0.4256 & 0.1207 & 0.0138 & 3.541 & 4780.0 \\
426 & CA665 & 0.3780 & 0.1542 & 0.0255 & 3.880 & 5225.0 \\
427 & CA909 & 0.3867 & 0.1567 & 0.0302 & 4.378 & 1935.0 \\
432 & CA919 & 0.3734 & 0.1952 & 0.0477 & 4.808 & 2046.0 \\
435 & CA652 & 0.3750 & 0.1918 & 0.0410 & 4.318 & 2263.0 \\
437 & CA646 & 0.4024 & 0.2432 & 0.0692 & 5.234 & 1295.0 \\
438 & CA670 & 0.3984 & 0.2018 & 0.0561 & 5.471 & 1566.0 \\
439 & CA913 & 0.3784 & 0.1676 & 0.0335 & 4.338 & 1437.0 \\
440 & CA617 & 0.3593 & 0.1621 & 0.0317 & 4.261 & 2840.0 \\
442 & CA669 & 0.4363 & 0.1628 & 0.0454 & 6.302 & 828.5 \\
443 & CA667 & 0.3509 & 0.1572 & 0.0300 & 4.210 & 4655.0 \\
444 & CA666 & 0.3971 & 0.1864 & 0.0410 & 4.543 & 3456.0 \\
446 & CA668 & 0.3859 & 0.2090 & 0.0531 & 4.889 & 2476.0 \\
450 & CA639 & 0.3558 & 0.1593 & 0.0260 & 3.710 & 5026.0 \\
452 & CA931 & 0.3516 & 0.1265 & 0.0131 & 3.004 & 6075.0 \\
453 & CA614 & 0.3566 & 0.2039 & 0.0534 & 4.978 & 2392.0 \\
454 & CA644 & 0.3737 & 0.2022 & 0.0435 & 4.249 & 3375.0 \\
457 & CA627 & 0.4054 & 0.2203 & 0.0662 & 5.721 & 1209.0 \\
461 & CA609 & 0.3563 & 0.2224 & 0.0695 & 5.731 & 924.8 \\
675 & CA635 & 0.3547 & 0.1826 & 0.0373 & 4.165 & 4147.0 \\
696 & CA618 & 0.3585 & 0.1437 & 0.0189 & 3.332 & 4022.0
\end{tabular}


Figure 13. Bedrock-Properties File for sample problem.

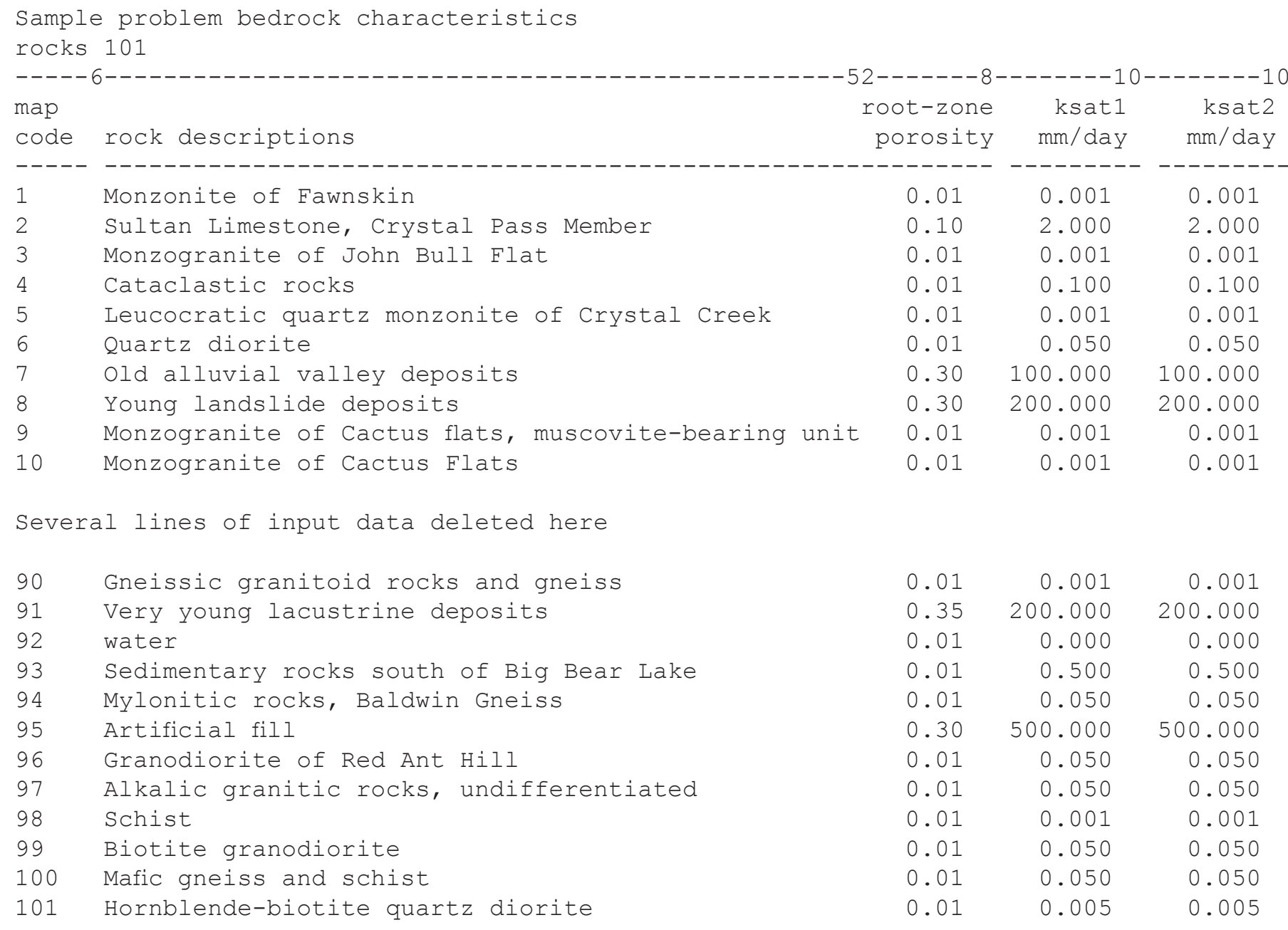


modified during the model calibration; however, the initial estimates of vertical hydraulic conductivity were increased by a factor of about 5 during model calibration. The average thickness of the bedrock layer in the sample watershed is $0.82 \mathrm{~m}$.

For the calculation of infiltration capacities from soil and bedrock saturated hydraulic conductivities by equations 18, 19, and 44, the duration of summer and winter storms (variables stormsum and stormwin in the Simulation-Control File) were set to 2 and 12 hours, respectively; the duration of the daily snowmelt period (variable melttime in the Simulation-Control File) was set to a value of 8 hours. Summer rainstorms were assumed to occur between Julian days 183 (variable dysumbeg) and 274 (dysumend), which correspond to July 2 and October 1.

Vegetation variables such as vegetation cover (estimated as a function of vegetation type) and root-zone variables including root-zone thickness are specified in the VegetationProperties File, an example of which is given in figure 14 (file sample.veget). These values were estimated by using the digital map provided by California Land Cover Mapping and Monitoring Program (2004). Vegetation-density estimates were based on a vegetation canopy map from the U.S. Geological Survey seamless Web site (Huang and others, 2001). Root-zone thickness is defined by vegetation variables unless soil-zone thickness is limiting, in which case the root-zone thickness is equal to soil-zone thickness. If soil-zone thickness is limiting and the vegetation is forest trees, then bedrock can be included in the root-zone thickness, allowing for the penetration of forest-tree roots into bedrock.

In the simulations of the Big Bear area, surface-waterflow routing was coupled with the root-zone water balance (variable irout was set to 1 in the Simulation-Control File) to allow run-on to each of the model cells to infiltrate back into the soil zone. A set of input variables provided in the Simulation-Control File was used to estimate stream-channel characteristics that were assumed to affect the quantity of routed surface-water run-on that could potentially infiltrate back into the root zone during the SWINFIL routing process. The variables defining stream-channel characteristics are ichanmod, chan1, chan2, chan3, and chan4 and ikschnmod, kschn1, kschn2, and kschn3. These variables are used to define an empirical model that controls the relative magnitude of the saturated soil or bedrock vertical hydraulic conductivity in stream channels as a function of upstream area, streambed slope, and the magnitude of the simulated run-on.

The empirical model is used to represent the difference in the area of a grid cell relative to its conceptual wetted area covered by routed surface water. The model is based on the assumption that infiltration of surface water back into the root zone during the routing process is dependent on the wetted area (the greater the wetted area, the greater the infiltration capacity). For low-order channels having small upstream areas and generally subjected to small volumes (depths) of routed surface water, a smaller wetted area is defined by the empirical model. Additionally, smaller wetted areas are assumed for grid cells having greater slope (for example, cells representing narrower, steeper channels). For high-order channels with large upstream areas and subjected to high volumes of routed surface water, a larger wetted area is defined by the empirical model.

Differences in the wetted area relative to the area of a grid cell are represented by adjusting the effective saturated vertical hydraulic conductivity of the soil or bedrock underlying the channel. For the low-order channels assumed to have smaller wetted areas relative to the grid cell area, the effective saturated vertical hydraulic conductivity is reduced to limit the infiltration capacity of the channel bed. For high-order channels assumed to have larger wetted areas relative to the grid cell area, the effective saturated vertical hydraulic conductivity is increased to enhance the infiltration capacity of the channel bed (the wetted area can be greater than the area of a grid cell).

For the sample problem, ichanmod was set to 1 , chan1 was set to 0.20 (the effective wetted area for runoff is assumed to be 20 percent of the grid cell area), chan 2 was set to 500 , chan 3 was set to 0.8 , and chan 4 was set to 2.0 . The ikschnmod option was set to 0 , and thus the vertical hydraulic conductivity of the streambed material was assumed to be the same as the vertical hydraulic conductivity of the interchannel areas.

\section{Simulation Results}

INFIL3.0 generates several output files that provide results of each simulation. Selected output for the sample problem is provided here to demonstrate some of the timeseries, spatial, and summary output. All of the output files generated by the simulation are listed in table 1 .

Figure 15 shows the summary output file (file sample. outfile) created during the simulation. The first two blocks of the output file list the names of most input and output files for the simulation. The next two blocks of information provide a summary of some of the climate-input and watershedcharacteristics data. The next block provides a summary of the simulation starting and ending dates and the simulation averaging period. The last block of information summarizes several of the water-balance terms for the averaging period, which for the sample problem is January 1, 1965 through December 31, 1970 (a total of 2,191 days). The water-balance terms represent, on a long-term basis, hydrologic conditions in the basin. For example, results shown in the output file indicate that precipitation as rain and snow account for about 67 and 33 percent of the total precipitation in the watershed, respectively. Information in the table also indicates that the average annual actual evapotranspiration within the soil zone ( $497.1 \mathrm{~mm} / \mathrm{yr}$ ) is about 39.8 percent of the adjusted potential evapotranspiration (that is, the potential evapotranspiration adjusted for cloudy days and sublimation) within the watershed $(1,248.3 \mathrm{~mm} / \mathrm{yr})$. The last section of this block provides a summary of the root-zone mass balance based on the water-budget components given in equation 2 . The massbalance summary indicates a very small mass-balance error for the simulation on the order of $10^{-12} \mathrm{~mm} / \mathrm{yr}$. 
Figure 14. Vegetation-Properties File for sample problem.

[The record of input data for each grid cell wraps onto two lines of text.]

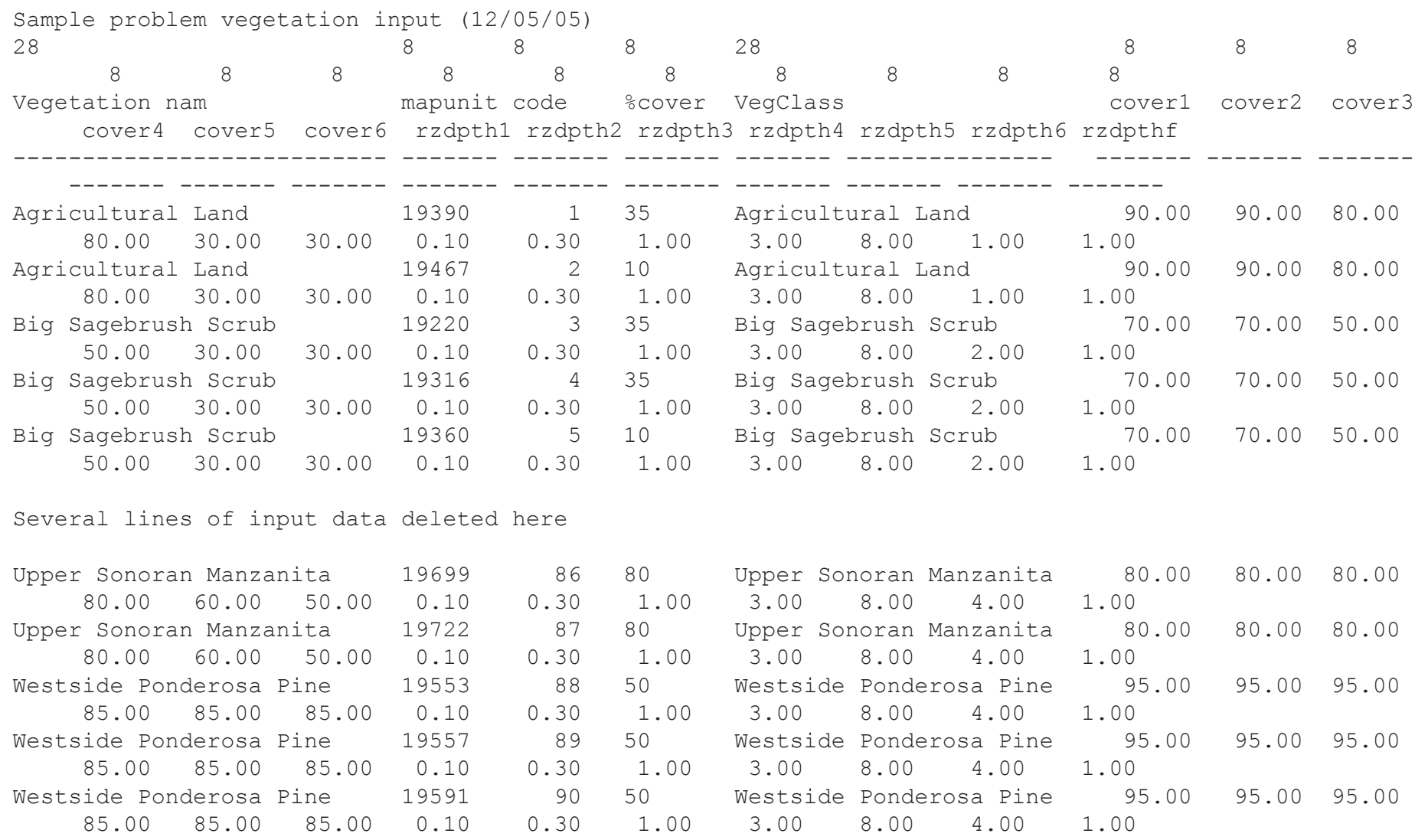


Figure 15. Summary Output File for sample problem.

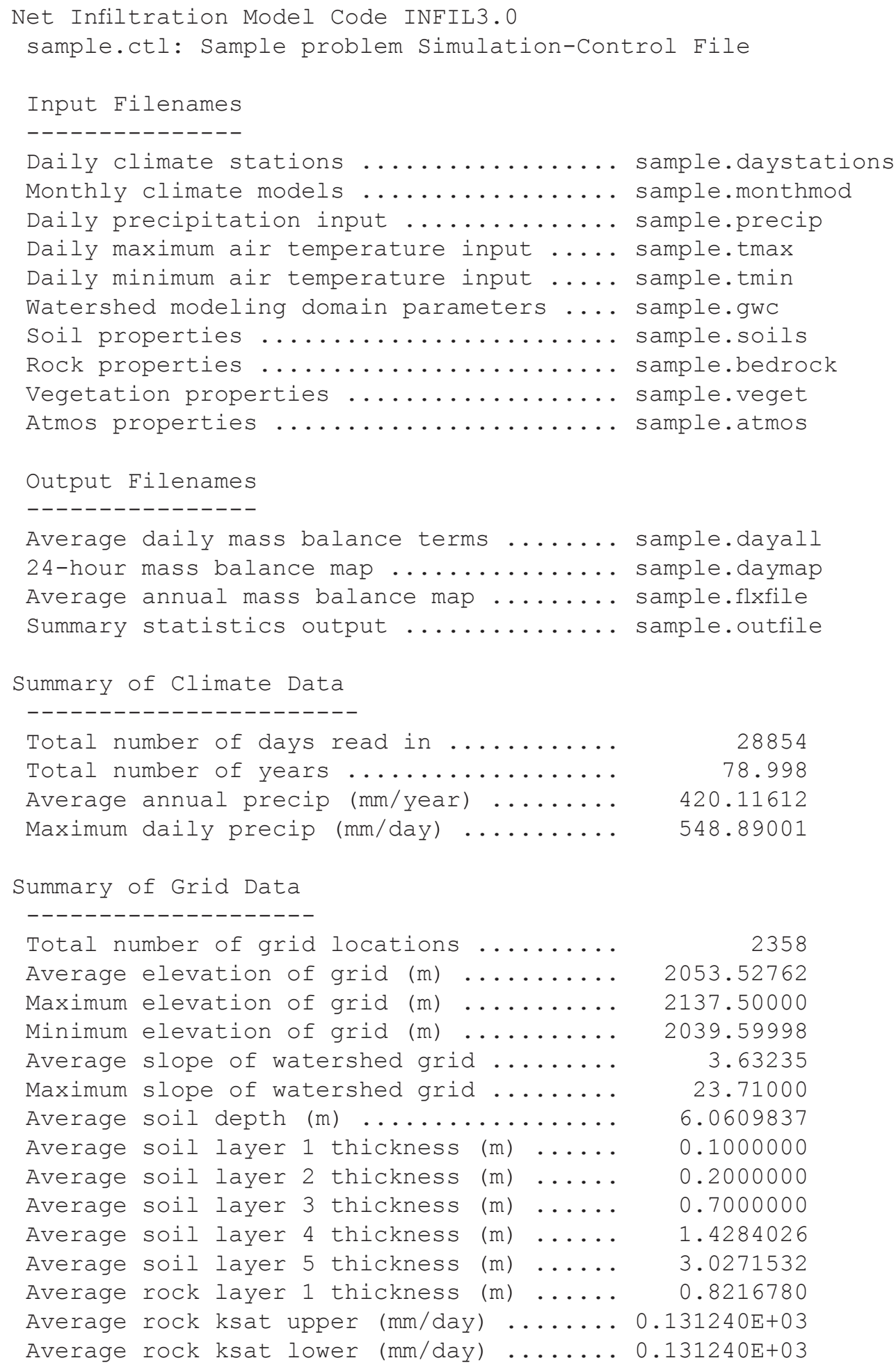


Figure 15. Summary Output File for sample problem.-Continued

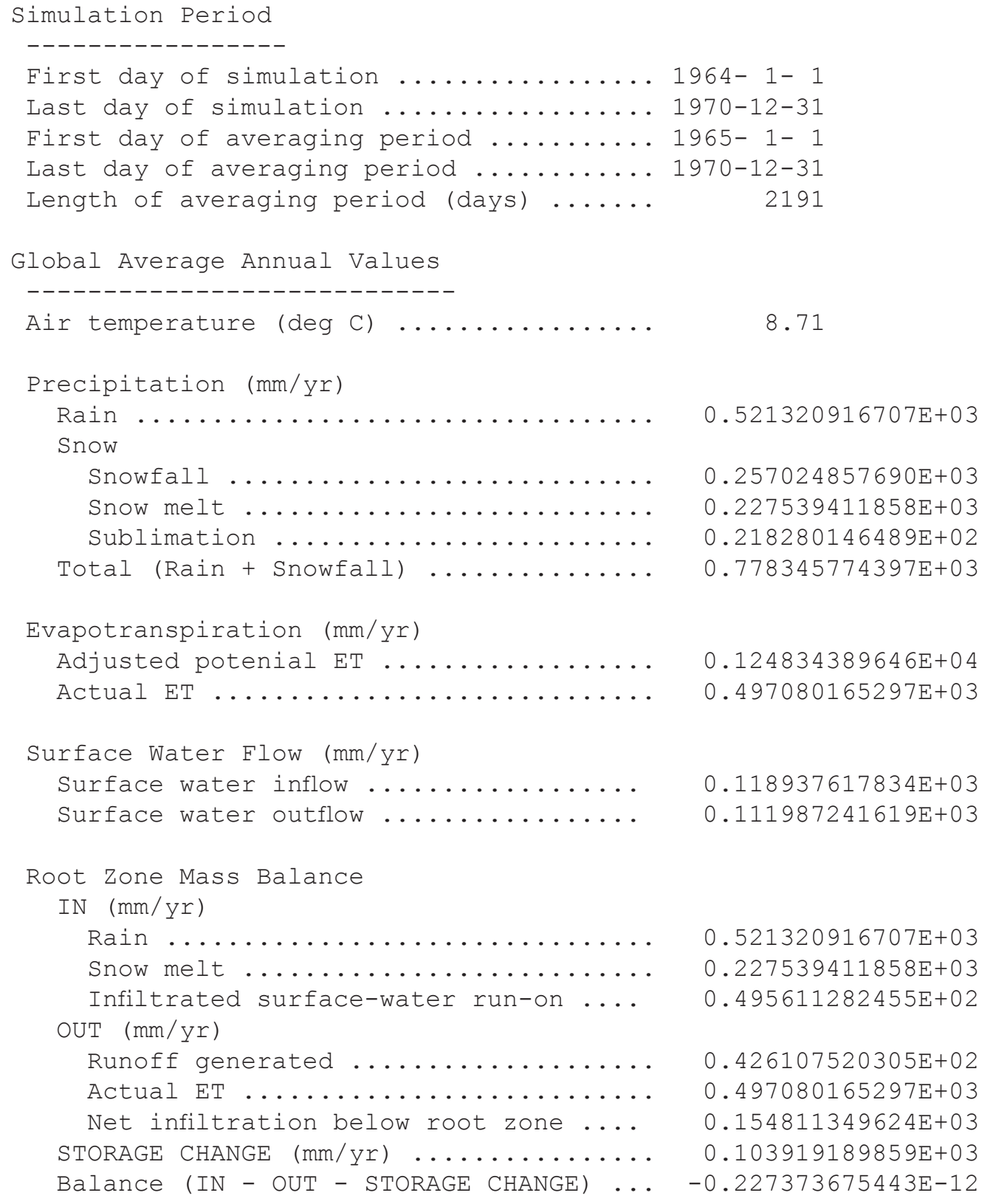


The graphs on figure 16 show five of the daily waterbudget components calculated for the sixth grid cell specified in the Simulation-Control File (from output file sample. point6). The cell is located along the main stream channel on the downstream end of the basin, near the basin outflow point. The top graph (fig. 16A) shows daily precipitation as rain (output variable rain) and daily snowmelt (output variable snowmelt) to the grid cell. The middle graph (fig. 16B) shows the daily actual evapotranspiration from the soil zone (output variable et), which is a small budget component at this cell, and the daily change in water content within the soil zone at the cell (output variable delta-storage). The bottom graph (fig. 16C) shows net infiltration at the cell (output variable net-infil3).

Figure 17 is a map of average annual net infiltration calculated for the averaging period. The data shown on the map represent net-infiltration values written to the file sample.flxfile (output variable net-infil3). Results obtained for the sample problem indicate the high range of net infiltration caused by the combination of the various factors and processes controlling net infiltration (fig. 17). Results include a maximum value of $12,496 \mathrm{~mm} / \mathrm{yr}$ for a single cell in the northeast part of the catchment, and minimum values of zero in the southern part of the catchment. The mean net-infiltration rate is $154.8 \mathrm{~mm} / \mathrm{yr}$ (fig. 15). Values greater than approximately $500 \mathrm{~mm} / \mathrm{yr}$ indicate enhanced net infiltration caused by infiltrating surfacewater run-on for grid cells along the boundary between impervious upstream areas generating runoff and more pervious downstream areas. For example, the zone of higher than average values (greater than 1,000 mm/yr) in the southern part of the sample catchment is along the base of a steep north-facing side slope having thin soil and low-permeability bedrock. The runoff generated from this side slope readily infiltrates into the higher permeability unconsolidated deposits downstream from the side slope. The high net-infiltration rates (greater than $2,000 \mathrm{~mm} / \mathrm{yr}$ ) in the northeastern part of the sample catchment are also in the more permeable unconsolidated deposits directly downstream from small drainage areas having thin soils and underlain by low-permeability bedrock. The maximum rate of 12,496 mm/yr was calculated for a channel location affected by a high frequency of focused runoff from the upstream drainage.

Net infiltration also is enhanced by infiltrating surfacewater run-on along the main channel running through the central part of the sample catchment. Net infiltration in the main channel is calculated to be approximately $300 \mathrm{~mm} / \mathrm{yr}$, compared to about $150 \mathrm{~mm} / \mathrm{yr}$ for the area alongside the channel. Although the average streamflow rate in the main channel is high — about 5,000 to $10,000 \mathrm{~mm} / \mathrm{yr}$ per unit area of grid cell-it is not as high as in the channel of the small drainage area in the northeastern part of the study area, where maximum streamflow rates are more than $200,000 \mathrm{~mm} / \mathrm{yr}$ per unit area of grid cell. The streamflow rates are higher because of the higher frequency of streamflow in the small drainage area. Water flows in the main channel only in response to inflows from the upstream subbasins. Runoff generated within the sample basin is generally routed only a short distance before channel losses reduce the streamflow to zero, and thus does not reach the main channel.

Net infiltration also is affected by soil thickness, geology, soil type, and vegetation properties. Net-infiltration rates are calculated to be 200 to $500 \mathrm{~mm} / \mathrm{yr}$ at locations having a thin root-zone soil layer (about $1.1 \mathrm{~m}$ ) underlain by unconsolidated sediments with relatively high permeability. In contrast, net infiltration is only 100 to $200 \mathrm{~mm} / \mathrm{yr}$ at locations with a thick root-zone soil layer of $6 \mathrm{~m}$ (central part of sample catchment), with the exception of the streamflow-enhanced net infiltration of 200 to $500 \mathrm{~mm} / \mathrm{yr}$ in the main channel. In general, net infiltration is higher at locations underlain by unconsolidated deposits than at locations underlain by consolidated bedrock. Net infiltration in the southernmost part of the sample basin is approximately $0 \mathrm{~mm} / \mathrm{yr}$ because the vertical hydraulic conductivity of rock type 76 (Quartzite of Wildhorse Meadows) is only $0.001 \mathrm{~mm} /$ day. Net infiltration for the consolidated rock in the northeastern part of the sample basin is higher (about 5 to $50 \mathrm{~mm} / \mathrm{yr}$ ) because the vertical hydraulic conductivity is higher (0.05 mm/day) for rock type 18 (Baldwin Gneiss). Within the area of rock type 18 , higher net-infiltration rates of 10 to $50 \mathrm{~mm} / \mathrm{yr}$ were calculated for locations with soil type 444, whereas net-infiltration rates were 5 to $50 \mathrm{~mm} / \mathrm{yr}$ for locations with soil type 442; these rates are a function of the saturated vertical hydraulic conductivity, which is $681 \mathrm{~mm} /$ day for soil type 444, substantially higher than the saturated vertical hydraulic conductivity of $234 \mathrm{~mm} /$ day for soil type 442 . Within the area of unconsolidated deposits having a root-zone soil layer of $6 \mathrm{~m}$, the lowest net-infiltration rates of 10 to $100 \mathrm{~mm} / \mathrm{yr}$ were calculated for locations with the PinyonJuniper vegetation type (19286 and 19375). The estimated vegetation cover was higher and root densities were deeper for the Pinyon-Juniper locations compared to locations with vegetation type 19467 (agricultural land). The simulated evapotranspiration rates for locations with Pinyon-Juniper in unconsolidated deposits were about 520 to $600 \mathrm{~mm} / \mathrm{yr}$, compared to 440 to $480 \mathrm{~mm} / \mathrm{yr}$ for locations represented as agricultural land. The higher root densities estimated for the lower root zone layers at locations with Pinyon-Juniper vegetation were more critical in reducing net infiltration than the higher root densities in the shallow root-zone layers at locations represented as agricultural lands. 

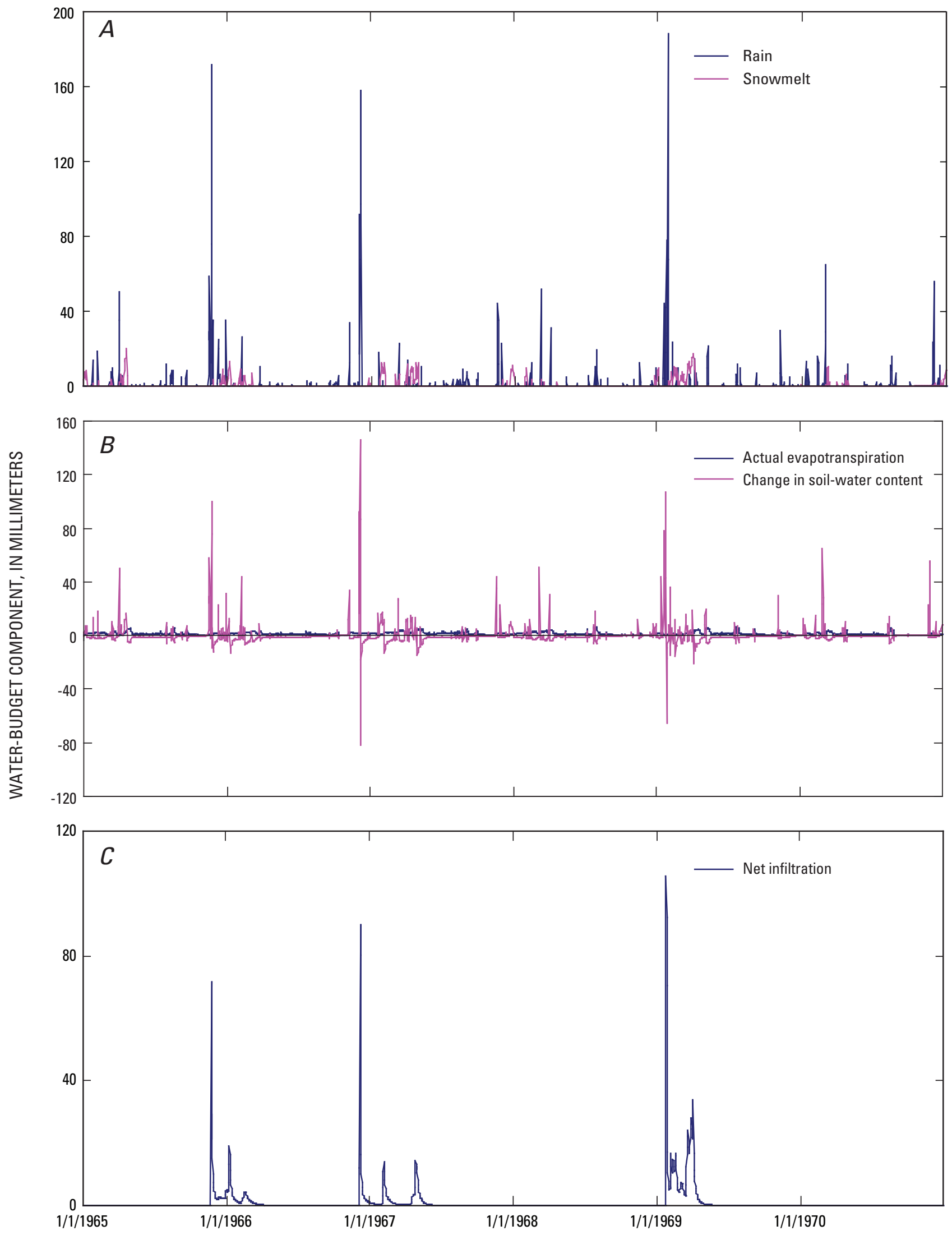

Figure 16. Selected model-calculated daily water-budget terms for a model cell in the sample-problem simulation: $(A)$ rain and snowmelt, $(B)$ actual evapotranspiration from the soil zone and change in water content within the soil zone, and $(C)$ net infiltration. 


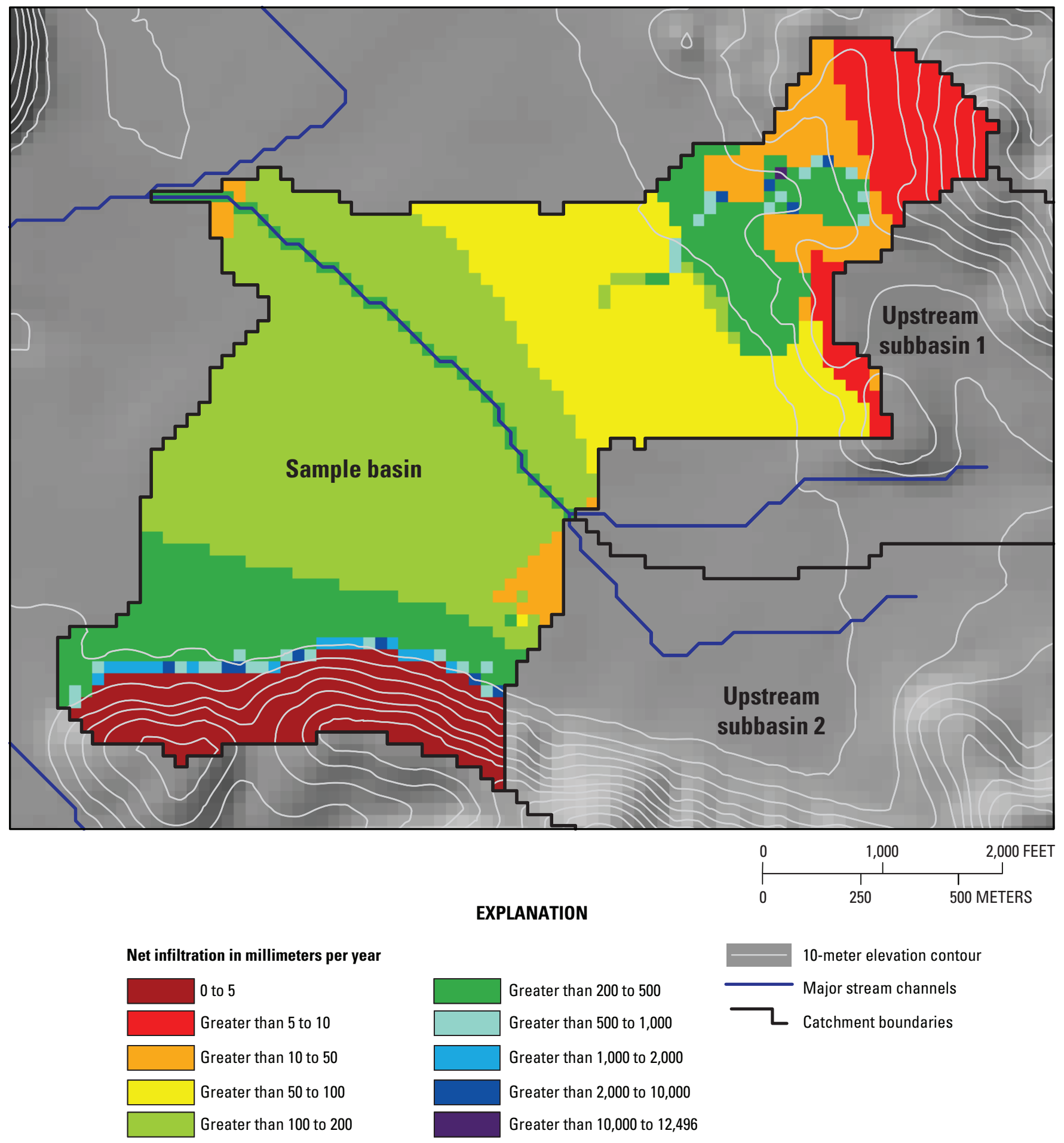

Figure 17. Model-calculated net infiltration for sample-problem simulation. 


\section{Summary}

The estimation of net infiltration of water below the root zone is important for quantifying the potential recharge to an underlying water-table aquifer. Although many methods are available to estimate net infiltration and (or) ground-water recharge, one of the most technically advanced is watershed modeling, which allows for the determination of temporally distributed net infiltration and recharge at locations distributed throughout a watershed. This report documents one such watershed model — the INFIL3.0 computer code.

INFIL3.0 is a grid-based, distributed-parameter, deterministic precipitation-runoff and net-infiltration waterbalance simulation model. The daily water balance simulated by INFIL3.0 includes precipitation as either rain or snow; snowfall accumulation, sublimation, and snowmelt; infiltration into the root zone; evapotranspiration from the root zone; drainage and water-content redistribution within the root-zone profile; surface-water runoff from, and run-on to, adjacent grid cells; and net infiltration. Net infiltration is defined as the downward drainage of water across the lower boundary of the root zone, in which the bottom of the root zone is the estimated maximum depth below ground surface affected by evapotranspiration.

Net infiltration consists of three possible water sourcesrain, snowmelt, and surface-water run-on (runoff and streamflow) to each grid cell within the simulation domain. These three sources are inputs to a layered root zone with one to five soil layers (that is, model-grid layers) and a lower bedrock, or deep-alluvium, grid layer. For each model cell, the number and thickness of layers is dependent on soil thickness, with the thickness of the lower bedrock layer increasing with decreasing soil thickness.

The water-balance model uses daily climate records of precipitation and air temperature and a spatially distributed representation of drainage-basin characteristics defined by topography, geology, soils, and vegetation to simulate daily net infiltration at all locations, including stream channels with intermittent streamflow in response to runoff from rain and snowmelt. The model does not simulate streamflow originating as ground-water discharge or the rise of a water table into the root zone. Drainage-basin characteristics are represented in the model by a set of spatially distributed input variables uniquely assigned to each grid cell of a model grid.

INFIL3.0 simulation results include a continuous time series of the daily water balance for the root zone (and for the individual root-zone layers). The daily time-series output includes simulated runoff (streamflow for channel locations), which can be compared to measured streamflow for model calibration. A primary benefit of the INFIL3.0 modeling approach is the generation of spatially detailed daily, annual, and average annual values representing all components of the water-balance model; these simulated results help to provide an understanding of the mechanisms responsible for net infiltration, runoff, and potential recharge. Model results can be mapped and subsequently used to evaluate the integrated effect of spatially distributed climate, terrain, and watershed characteristics (for example, vegetation, soils, and geology) on the spatial distribution of runoff and potential recharge.

INFIL3.0 was developed for application to arid and semiarid climates where surface-water flow consists primarily of overland runoff from rain and snowmelt, as opposed to base flow from ground-water discharge. INFIL3.0 may have limited applicability for study areas characterized by humid climates, thin unsaturated zones, perennial streamflow with significant contributions from ground-water discharge, and a high percentage of cloudy days with no precipitation (for example, coastal areas subject to foggy conditions). All streamflow simulated by INFIL3.0 is assumed to be routed through the entire study area within the 1-day time step. Therefore, study areas characterized by streamflow with a substantial lag-time relative to the generation of runoff may not be appropriate for an INFIL3.0 application.

Applications of earlier versions of the INFIL3.0 code have been made to the Yucca Mountain area of Nevada; the Death Valley region of Nevada and California within which Yucca Mountain is located; and the Joshua Tree, San Gorgonio Pass (Riverside County), and Big Bear Lake areas of California. INFIL3.0 data sets prepared for one of the subbasins within the Big Bear Lake watershed were used as the basis for a sample problem described in this report to demonstrate how INFIL3.0 can be applied to a field setting and to demonstrate the input and output files of an INFIL3.0 simulation.

\section{References}

California Land Cover Mapping and Monitoring Program, 2004, Geographic Information System layer of vegetation (CALVEG and WHR) from 1997-2002 Landsat TM, tiled by county with a 2.5 acre minimum mapping unit: data available on the World Wide Web, accessed August 28, 2004, at URL http://frap.cdf.ca.gov/data/ frapgisdata/accept_spatial.asp?spatialdist $=2 \&$ rec $=$ cveg

Campbell, G.S., 1977, An introduction to environmental biophysics ( $2 \mathrm{~d}$ ed.): New York, N.Y., Springer-Verlag, $159 \mathrm{p}$.

Campbell, G.S., and Norman, J.M., 1998, An introduction to environmental biophysics ( $2 \mathrm{~d}$ ed.): New York, N.Y., Springer, $286 \mathrm{p}$.

Davies, J.A., and Allen, C.D., 1973, Equilibrium, potential and actual evaporation from cropped surfaces in southern Ontario: Journal of Applied Meteorology, v. 12, p. 649-657. 
de Bruin, H.A.R., 1988, Evaporation in arid and semi-arid regions, in Simmers, Ian, ed., Estimation of natural groundwater recharge: Boston, Reidel Publishing Company, p. 73-88.

EarthInfo, Inc., 2004, NCDC Summary of the Day. West: Boulder, Colo., EarthInfo, Inc., CD ROM West 1.

Eichinger, W.E., Parlange, M.B., and Stricker, Han, 1996, On the concept of equilibrium evaporation and the value of the Priestley-Taylor coefficient: Water Resources Research, v. 32, no. 1, p. 161-164.

Flint, A.L., and Childs, S.W., 1987, Calculation of solar radiation in mountainous terrain: Agricultural and Forest Meteorology, v. 40, p. 233-249.

Flint, A.L., and Childs, S.W., 1991, Use of the Priestley-Taylor evaporation equation for soil water limited conditions in a small forest clearcut: Agricultural and Forest Meteorology, v. 56 , p. $247-260$.

Flint, A.L., Flint, L.E., Hevesi, J.A., and Hudson, D.B., 2001, Characterization of arid land infiltration processes at Yucca Mountain, Nevada, in Evans, D.S., Rasmussen, T.C., and Nicholson, T.J., eds., (2d ed.) Flow and transport through unsaturated fractured rock: American Geophysical Union, Geophysical Monograph Series, v. 42, p. 135-149.

Gray, D.M., and Prowse, T.D., 1993, Snow and floating ice, in Maidment, D.R., ed., Handbook of hydrology: New York, N.Y., McGraw-Hill, Inc., chap. 7.

Hevesi, J.A., Flint, A.L., and Flint, L.E., 2002, Preliminary estimates of spatially distributed net infiltration and recharge for the Death Valley Region, Nevada-California: U.S. Geological Survey Water-Resources Investigations Report 02-4010, 36 p.

Hevesi, J.A., Flint, A.L., and Flint, L.E., 2003, Simulation of net infiltration and potential recharge using the distributedparameter watershed model of the Death Valley region, Nevada and California: U.S. Geological Survey WaterResources Investigations Report 03-4090, 171 p.

Huang, Chengquan, Yang, Limin, Wylie, Bruce, and Homer, Collin, 2001, A strategy for estimating tree canopy density using Landsat 7 ETM+ and high resolution images over large areas, in Proceedings of the Third International Conference on Geospatial Information in Agriculture and Forestry, November 5-7, 2001: Denver, Colo., data available on the World Wide Web, accessed August 28, 2004, at URL http://gisdata.usgs.net/Website/Seamless/viewer.htm
Iqbal, Muhammad, 1983, An introduction to solar radiation: New York, Academic Press, 390 p.

Jury, W.A., Gardner, W.R., and Gardner, W.H., 1991, Soil physics (5th ed.): New York, John Wiley and Sons, 328 p.

Maidment, D.R., ed., 2002, Arc Hydro-GIS for water resources: Redlands, Calif., ESRI Press, 203 p.

Nishikawa, Tracy, Izbicki, J.A., Hevesi, J.A., Stamos, C.L., and Martin, Peter, 2004, Evaluation of geohydrologic framework, recharge estimates, and ground-water flow of the Joshua Tree area, San Bernardino County, California: U.S. Geological Survey Scientific Investigations Report 2004-5267, $115 \mathrm{p}$.

Priestley, C.H.B., and Taylor, R.J., 1972, On the assessment of surface heat flux and evaporation using large-scale parameters: Manual Weather Review, v. 100, p. 81-92.

Rewis, D.L., Christensen, A.H., Matti, J.C., Hevesi, J.A., Nishikawa, Tracy, and Martin, Peter, 2006, Geology, ground-water hydrology, geochemistry, and ground-water simulation of the Beaumont and Banning storage units, San Gorgonio Pass area, Riverside County, California: U.S. Geological Survey Scientific Investigations Report 2005-5026, 173 p.

Shuttleworth, J.W., 1993, Evaporation, in Maidment, D.R., ed., Handbook of hydrology: New York, N.Y., McGraw-Hill, Inc., chap. 4.

Stannard, D.I., 1993, Comparison of Penman-Monteith, Shuttleworth-Wallace, and the modified Priestley-Taylor evapotranspiration models for wildland vegetation in semiarid rangelands: Water Resources Research, v. 29, no. 5, p. 1379-1392.

Stewart, R.B., and Rouse, W.R., 1977, Substantiation of the Priestley and Taylor parameter $\alpha=1.26$ for potential evaporation in high latitudes: Journal of Applied Meteorology, v. 16, p. 649-650.

U.S. Department of Agriculture (Natural Resource Conservation Service), 1994, State soil geographic (STATSGO) data base-Data use information: Miscellaneous Publication 1492. 


\section{Appendix 1. Supplemental Tables}

\section{Tables}

1-1. Definitions of variables specified in the Simulation-Control File. . .52

1-2. Definitions for column headings printed to the grid-cell properties output file...............56

1-3. Definitions for column headings printed for specific dates to the daily output file for each grid cell

1-4. Definitions for column headings printed to the daily output file for specific grid cells

1-5. Definitions for column headings printed to the annual and average annual output files for all grid cells

1-6. Definitions for column headings printed to the daily and cumulative output file for the last successful day of a simulation

1-7. Definitions for column headings printed to the daily output file for the spatially averaged water-budget components

1-8. Definitions for column headings printed to the monthly and annual output files for all grid cells......

1-9. Definitions of variables printed to the average annual output file for each grid cell .....63 
Table 1-1. Definitions of variables specified in the Simulation-Control File.

[Numbers in parentheses after the variable type indicate the size of the variable. Double precision indicates a real variable type]

\begin{tabular}{|c|c|c|c|c|}
\hline Record & Variable name & Variable type & Explanation & Units \\
\hline 1 & title & Character & Title for the simulation (up to 250 characters). & dimensionless \\
\hline 2 & irout $^{1}$ & Integer & $\begin{array}{l}\text { Flag specifying the type of flow routing to be simulated. Options: } \\
\text { irout }=0 \text {, surface-water routing is decoupled from the root-zone water } \\
\text { balance; irout }=1 \text {, surface-water routing is coupled with the root-zone } \\
\text { water balance; irout }=-1 \text {, no flow routing will be done. }\end{array}$ & dimensionless \\
\hline 3 & petadj $^{1}$ & $\begin{array}{l}\text { Double } \\
\text { precision }\end{array}$ & $\begin{array}{l}\text { Empirical adjustment factor to the calculated potential evapotranspiration } \\
\text { to account for cloud cover (precipitation). }\end{array}$ & 1/millimeters \\
\hline \multirow[t]{2}{*}{4} & isnow & Integer & $\begin{array}{l}\text { Flag specifying whether or not snow accumulation, melting, and sublima- } \\
\text { tion will be simulated. Options: isnow }=0 \text {, snow processes will not be } \\
\text { simulated, and all precipitation will be assumed to be rain; isnow }=2 \text {, } \\
\text { snow processes will be simulated. }\end{array}$ & dimensionless \\
\hline & melttime & $\begin{array}{l}\text { Double } \\
\text { precision }\end{array}$ & Duration of the daily snowmelt. & hours \\
\hline \multirow[t]{4}{*}{5} & snoday1 & Integer & Starting (Julian) day for early spring snowmelt period. & dimensionless \\
\hline & snopar1 & Real & Snowmelt rate for early spring snowmelt period. & millimeters/day \\
\hline & snoday 2 & Integer & Starting (Julian) day for late spring snowmelt period. & dimensionless \\
\hline & snopar2 & Real & Snowmelt rate for late spring snowmelt period. & millimeters/day \\
\hline \multirow[t]{3}{*}{6} & isublim & Integer & $\begin{array}{l}\text { Flag specifying whether or not sublimation will be simulated. } \\
\text { Options: isublim }=0 \text {, sublimation will not be simulated; isublim }=1 \text {, } \\
\text { sublimation will be simulated. }\end{array}$ & dimensionless \\
\hline & subpar1 & Real & Sublimation factor for air temperature less than or equal to $0^{\circ}$ Celsius. & dimensionless \\
\hline & subpar2 & Real & Sublimation factor for air temperature greater than $0^{\circ}$ Celsius. & dimensionless \\
\hline \multirow[t]{2}{*}{7} & ipptval & Integer & $\begin{array}{l}\text { Flag specifying whether precipitation will be a constant value. } \\
\text { Options: ipptval }=0 \text {, precipitation will not be a constant value; } \\
\text { ipptval }=1 \text {, precipitation will be a constant value. }\end{array}$ & dimensionless \\
\hline & pptval & $\begin{array}{l}\text { Double } \\
\text { precision }\end{array}$ & Constant precipitation value for the simulation period. & millimeters \\
\hline \multirow[t]{2}{*}{8} & iairval & Integer & $\begin{array}{l}\text { Flag specifying whether air temperature will be a constant value. } \\
\text { Options: iairval = } 0 \text {, air temperature will not be a constant value; } \\
\text { iarval = } 1 \text {, air temperature will be a constant value. }\end{array}$ & dimensionless \\
\hline & airval & Real & Constant air-temperature value for simulation. & degrees Celsius \\
\hline \multirow[t]{2}{*}{9} & ietval & Integer & $\begin{array}{l}\text { Flag specifying whether evapotranspiration will be a constant value. } \\
\text { Options: ietval }=0 \text {, evapotranspiration will not be a constant value; } \\
\text { ietval }=1 \text {, evapotranspiration will be a constant value. }\end{array}$ & dimensionless \\
\hline & etval & $\begin{array}{l}\text { Double } \\
\text { precision }\end{array}$ & Constant evapotranspiration for simulation. & millimeters \\
\hline \multirow[t]{2}{*}{10} & isdepthval & Integer & $\begin{array}{l}\text { Flag specifying whether a constant soil depth will be used for all grid cells. } \\
\text { Options: isdepthval }=1 \text {, a constant value will be used; isdepthval } \neq 1 \text {, } \\
\text { spatially variable depths will be used. }\end{array}$ & dimensionless \\
\hline & sdepthval & Real & Constant soil depth for all grid cells. & meters \\
\hline 11 & isksval $^{1}$ & Integer & $\begin{array}{l}\text { Flag specifying whether soil saturated vertical hydraulic conductivity will } \\
\text { be a constant value. Options: isksval }=0 \text {, soil saturated vertical hydrau- } \\
\text { lic conductivity will not be a constant value; isksval } \neq 0 \text {, soil saturated } \\
\text { vertical hydraulic conductivity will be a constant value (sksval). }\end{array}$ & dimensionless \\
\hline & sksval & Real & Constant soil saturated vertical hydraulic conductivity. & millimeters/day \\
\hline
\end{tabular}


Table 1-1. Definitions of variables specified in the Simulation-Control File.-Continued

[Numbers in parentheses after the variable type indicate the size of the variable. Double precision indicates a real variable type]

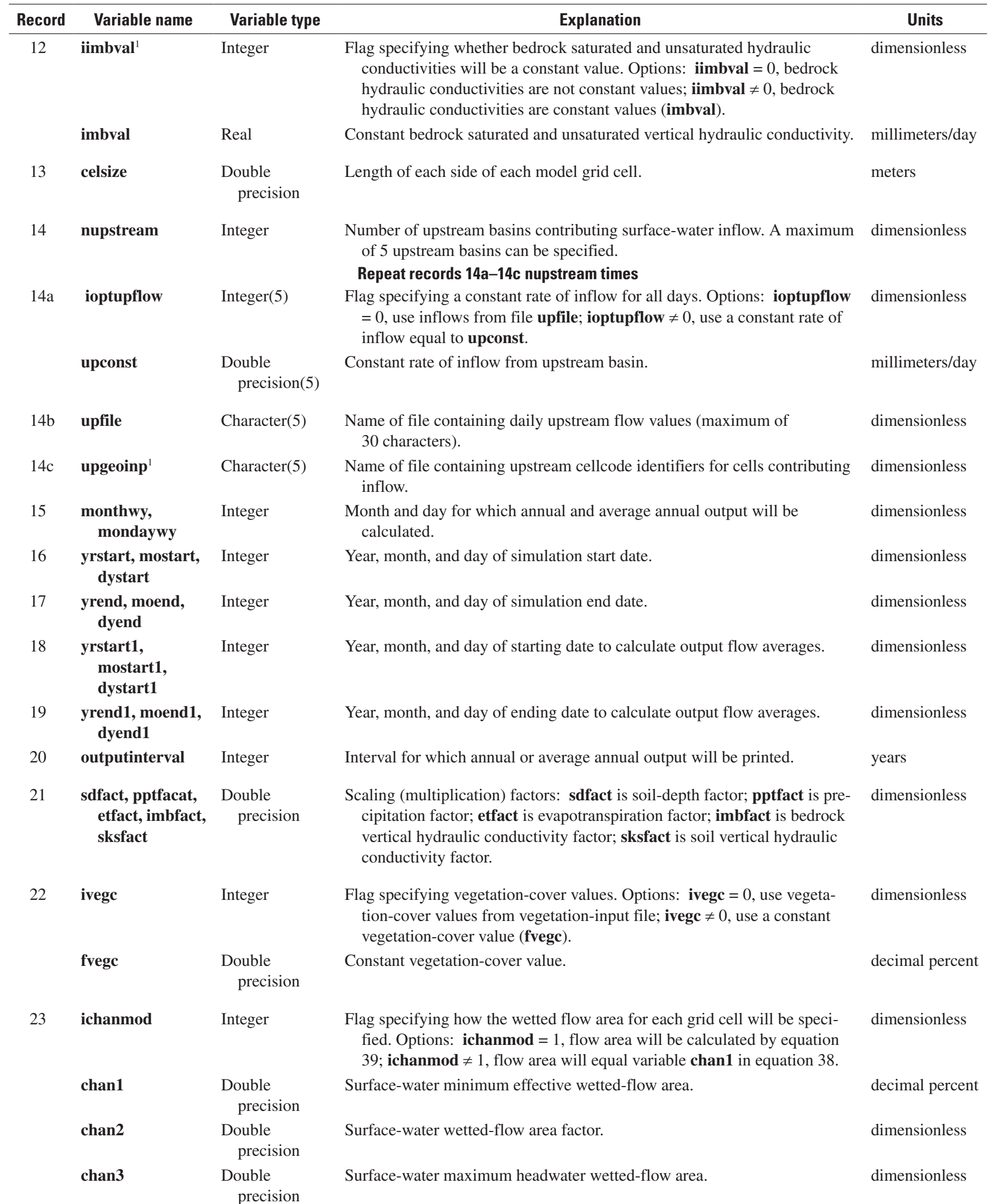


Table 1-1. Definitions of variables specified in the Simulation-Control File.-Continued

[Numbers in parentheses after the variable type indicate the size of the variable. Double precision indicates a real variable type]

\begin{tabular}{|c|c|c|c|c|}
\hline Record & Variable name & Variable type & Explanation & Units \\
\hline & chan4 & $\begin{array}{l}\text { Double } \\
\text { precision }\end{array}$ & Surface-water maximum stream-channel wetted-flow area. & dimensionless \\
\hline \multirow{2}{*}{24} & kschn2 & $\begin{array}{l}\text { Double } \\
\text { precision }\end{array}$ & $\begin{array}{l}\text { Scaling factor for adjusting soil saturated vertical hydraulic conductivity in } \\
\text { channels. }\end{array}$ & dimensionless \\
\hline & kschn3 & $\begin{array}{l}\text { Double } \\
\text { precision }\end{array}$ & $\begin{array}{l}\text { Maximum adjustment factor to the soil saturated vertical hydraulic conduc- } \\
\text { tivity in channels. }\end{array}$ & dimensionless \\
\hline \multirow[t]{2}{*}{25} & barsoil1 $^{1}$ & $\begin{array}{l}\text { Double } \\
\text { precision }\end{array}$ & $\begin{array}{l}\text { Variable } \beta \text { in modified Priestley-Taylor equation defining evaporation as a } \\
\text { function of bare-soil water content and potential evapotranspiration. }\end{array}$ & dimensionless \\
\hline & barsoilf $^{1}$ & $\begin{array}{l}\text { Double } \\
\text { precision }\end{array}$ & $\begin{array}{l}\text { Adjustment factor that can be used to modify the value of barsoil1 for } \\
\text { layer } 2 \text { of the model. }\end{array}$ & dimensionless \\
\hline \multirow[t]{2}{*}{26} & rocket1 $^{1}$ & Real & $\begin{array}{l}\text { Variable } \beta \text { in modified Priestley-Taylor equation defining transpiration as a } \\
\text { function of rock-matrix water content and potential evapotranspiration. }\end{array}$ & dimensionless \\
\hline & rocket $2^{1}$ & Real & $\begin{array}{l}\text { Variable } \alpha \text { in modified Priestley-Taylor equation defining transpiration as a } \\
\text { function of rock-matrix water content and potential evapotranspiration. }\end{array}$ & dimensionless \\
\hline \multirow[t]{2}{*}{27} & soilet1 $^{1}$ & Real & $\begin{array}{l}\text { Variable } \beta \text { in modified Priestley-Taylor equation defining transpiration as a } \\
\text { function of soil-water content and potential evapotranspiration. }\end{array}$ & dimensionless \\
\hline & soilet $2^{1}$ & Real & $\begin{array}{l}\text { Variable } \alpha \text { in the modified Priestley-Taylor equation used for defining } \\
\text { transpiration as a function of soil-water content and potential evapo- } \\
\text { transpiration. }\end{array}$ & dimensionless \\
\hline 31 & daystations & Character & $\begin{array}{l}\text { Name of Climate-Stations Information File (maximum of } \\
30 \text { characters). }\end{array}$ & dimensionless \\
\hline 32 & monthmod & Character & $\begin{array}{l}\text { Name of Monthly Climate Regression-Models File (maximum of } \\
30 \text { characters). }\end{array}$ & dimensionless \\
\hline 33 & daypptinput & Character & Name of Daily Precipitation File (maximum of 30 characters). & dimensionless \\
\hline 34 & tunit & Integer & $\begin{array}{l}\text { Flag to convert from degrees Fahrenheit to degrees Celsius in the air- } \\
\text { temperature/elevation regression models. If tunit }=1 \text {, temperatures are } \\
\text { converted from degrees Fahrenheit to degrees Celsius. }\end{array}$ & dimensionless \\
\hline 35 & daytmaxinput & Character & $\begin{array}{l}\text { Name of Daily Maximum Air-Temperature File (maximum of } \\
30 \text { characters). }\end{array}$ & dimensionless \\
\hline 36 & daytmininput & Character & $\begin{array}{l}\text { Name of Daily Minimum Air-Temperature File (maximum of } \\
30 \text { characters). }\end{array}$ & dimensionless \\
\hline 37 & soilprop & Character & Name of Soil-Properties File (maximum of 30 characters). & dimensionless \\
\hline 38 & rockprop & Character & Name of Bedrock-Properties File (maximum of 30 characters). & dimensionless \\
\hline 39 & atmosinput & Character & $\begin{array}{l}\text { Name of Monthly Atmospheric-Parameters File (maximum of } \\
30 \text { characters). }\end{array}$ & dimensionless \\
\hline 40 & vegprop & Character & Name of Vegetation-Properties File (maximum of 30 characters). & dimensionless \\
\hline
\end{tabular}


Table 1-1. Definitions of variables specified in the Simulation-Control File.-Continued

[Numbers in parentheses after the variable type indicate the size of the variable. Double precision indicates a real variable type]

\begin{tabular}{|c|c|c|c|c|}
\hline Record & Variable name & Variable type & Explanation & Units \\
\hline \multirow[t]{3}{*}{41} & initopt & Integer & $\begin{array}{l}\text { Flag for determining how initial soil-water content will be set. } \\
\text { Options: initopt }=0 \text {, initial conditions based on soil porosity; } \\
\text { initopt }=1 \text {, initial conditions based on residual soil-water content; } \\
\text { initopt }=3 \text {, initial conditions read from file restartfile. }\end{array}$ & dimensionless \\
\hline & \multirow[t]{2}{*}{ vwcfact } & \multirow[t]{2}{*}{$\begin{array}{l}\text { Double } \\
\text { precision }\end{array}$} & $\begin{array}{l}\text { Multiplication factor for setting initial soil-water content for each of the } \\
5 \text { soil layers. }\end{array}$ & dimensionless \\
\hline & & & \multicolumn{2}{|l|}{ Records $41 \mathrm{a}$ and $41 \mathrm{~b}$ are only read if initopt $=3$} \\
\hline $41 \mathrm{a}$ & restartfile & Character & $\begin{array}{l}\text { Name of file with several mass-balance terms for each grid cell for the last } \\
\text { successful day of a previous simulation (maximum of } 30 \text { characters). }\end{array}$ & dimensionless \\
\hline $41 b$ & ndayscrash & Integer & $\begin{array}{l}\text { Last day of successful simulation in a previous simulation that corresponds } \\
\text { to data in file restartfile. }\end{array}$ & dimensionless \\
\hline 42 & infile & Character & $\begin{array}{l}\text { Name of Geospatial Watershed-Characteristics File (maximum of } \\
30 \text { characters). }\end{array}$ & dimensionless \\
\hline 43 & crashfile & Character & $\begin{array}{l}\text { Name of program crash file to hold several mass-balance terms for each } \\
\text { grid cell for the last successful day of a simulation (maximum of } \\
30 \text { characters). }\end{array}$ & dimensionless \\
\hline 44 & dayall & Character & $\begin{array}{l}\text { Name of file for output of spatially averaged output terms for all grid-cell } \\
\text { locations for each successive day of a simulation (maximum of } \\
30 \text { characters). }\end{array}$ & dimensionless \\
\hline \multirow[t]{2}{*}{45} & \multirow[t]{2}{*}{ ndaymap } & \multirow[t]{2}{*}{ Integer } & $\begin{array}{l}\text { Number of daily output files of mass-balance results for each grid cell. } \\
\text { Maximum of } 100 \text { output files is allowed. Must be at least } 1 \text {. }\end{array}$ & \multirow[t]{2}{*}{ dimensionless } \\
\hline & & & Repeat records $45 a$ and $45 b$ ndaymap times & \\
\hline $45 \mathrm{a}$ & irday, nyrout & Integer(100) & $\begin{array}{l}\text { Sequential number of the Julian day (irday) and year (nyrout) to write } \\
\text { daily mass-balance results to a corresponding daymap file. }\end{array}$ & dimensionless \\
\hline $45 b$ & daymap & Character(100) & $\begin{array}{l}\text { Name of file for output of daily mass-balance terms for each grid cell } \\
\text { for specific days identified by irday and nyrout (maximum of } \\
30 \text { characters). }\end{array}$ & dimensionless \\
\hline 46 & pointfile(1) & Character(20) & $\begin{array}{l}\text { Name of file for output of daily mass-balance terms corresponding to the } \\
\text { last active grid cell in the model area (that is, the cell immediately above } \\
\text { the outflow cell) (maximum of } 30 \text { characters). }\end{array}$ & dimensionless \\
\hline 47 & ipointfile & Integer & $\begin{array}{l}\text { Number of additional output files of daily mass-balance terms at specific } \\
\text { grid cells. ipointfile must be less than or equal to } 19 \text { and can equal } 0 . \\
\text { Repeat records 47a and 47b ipointfile times }\end{array}$ & dimensionless \\
\hline $47 \mathrm{a}$ & xpoint, ypoint & $\begin{array}{l}\text { Double } \\
\quad \text { precision }(20)\end{array}$ & $\begin{array}{l}\text { East-west (easting; xpoint) and north-south (northing; ypoint) coordinates } \\
\text { of grid cell for output file of daily mass-balance terms. }\end{array}$ & meters \\
\hline $47 b$ & pointfile & Character(20) & $\begin{array}{l}\text { Name of file for output of daily mass-balance terms corresponding to } \\
\text { current xpoint, ypoint (maximum of } 30 \text { characters). }\end{array}$ & dimensionless \\
\hline 48 & outfile & Character & $\begin{array}{l}\text { Name of output file with summary information for the simulation, as } \\
\text { well as summary statistics for the entire simulation (maximum of } \\
30 \text { characters). }\end{array}$ & dimensionless \\
\hline 49 & flxfile & Character & $\begin{array}{l}\text { Name of output file with average annual mass-balance terms during aver- } \\
\text { aging period for each grid cell (maximum of } 30 \text { characters). }\end{array}$ & dimensionless \\
\hline 50 & spatialout & Character & $\begin{array}{l}\text { Name of output file to which summary information about spatial properties } \\
\text { for each grid cell is written (maximum of } 30 \text { characters). }\end{array}$ & dimensionless \\
\hline 51 & outyear1 & Character & $\begin{array}{l}\text { Prefix of the name of the output file for mass-balance terms for annual } \\
\text { totals or multiyear averages by grid cell (maximum of } 26 \text { characters). }\end{array}$ & dimensionless \\
\hline 52 & outannual & Character & $\begin{array}{l}\text { Name of file to hold total annual flow terms for the entire grid (maximum } \\
\text { of } 30 \text { characters). }\end{array}$ & dimensionless \\
\hline 53 & outmonth & Character & $\begin{array}{l}\text { Name of file to hold total monthly flow terms for the entire grid (maximum } \\
\text { of } 30 \text { characters). }\end{array}$ & dimensionless \\
\hline
\end{tabular}

${ }^{1}$ Additional information about this variable is provided in the text. 
Table 1-2. Definitions for column headings printed to the grid-cell properties output file.

[Water-budget terms are in millimeters unless otherwise noted]

\begin{tabular}{|c|c|}
\hline Column heading & Definition \\
\hline easting & Grid-cell east-west coordinate, in meters. \\
\hline northing & Grid-cell north-south coordinate, in meters. \\
\hline locid & Sequential grid-cell number. \\
\hline row & Row number of grid cell. \\
\hline col & Column number of grid cell. \\
\hline elev & Land-surface elevation of grid cell, in meters. \\
\hline slope & Land-surface slope of grid cell, degrees. \\
\hline aspect & Land-surface aspect of grid cell, degrees azimuth relative to north. \\
\hline upcells & Total number of upstream cells that contribute flow to the grid cell. \\
\hline soild & Total soil depth for grid cell (does not include bedrock thickness), in meters. \\
\hline soild1, ..., soild6 & Layer thickness for each layer of the grid cell, in meters. \\
\hline soil & Integer code for soil type of the grid cell. \\
\hline soilks & $\begin{array}{l}\text { Soil saturated vertical hydraulic conductivity of the grid cell, in millimeters } \\
\text { per day. }\end{array}$ \\
\hline resid & Residual soil-water content for the grid cell, dimensionless. \\
\hline fcap & Soil field capacity of the grid cell, dimensionless. \\
\hline sporo & Soil porosity of the grid cell, dimensionless. \\
\hline $\begin{array}{l}\text { lay } 1 \mathrm{~mm}, . . . \\
\text { lay } 5 \mathrm{~mm}\end{array}$ & Storage capacity of each soil layer of the grid cell, in millimeters. \\
\hline rockmm & Storage capacity of the bedrock layer of the grid cell, in millimeters. \\
\hline scapmmt & Total storage capacity of all six layers of the grid cell, in millimeters. \\
\hline rock & Integer code for bedrock type of the grid cell. \\
\hline $\mathbf{k s}(\mathbf{m m} / \mathbf{d y})$ & $\begin{array}{l}\text { Effective unsaturated vertical hydraulic conductivity for the bedrock layer of } \\
\text { the grid cell, in millimeters per day. }\end{array}$ \\
\hline $\mathbf{k s}(\mathbf{m m} / \mathbf{y r})$ & $\begin{array}{l}\text { Effective unsaturated vertical hydraulic conductivity for the bedrock layer of } \\
\text { the grid cell, in millimeters per year. }\end{array}$ \\
\hline
\end{tabular}


Table 1-3. Definitions for column headings printed for specific dates to the daily output file for each grid cell.

[Water-budget terms are in millimeters unless otherwise noted]

\begin{tabular}{|c|c|}
\hline Column heading & Definition \\
\hline cellcode & Grid-cell (node) number. \\
\hline easting & Grid-cell east-west coordinate. \\
\hline northing & Grid-cell north-south coordinate. \\
\hline elev & Land-surface elevation. \\
\hline temp & Average daily air temperature. \\
\hline swinflow & Surface-water inflow from upstream basins. \\
\hline precip & Daily precipitation. \\
\hline rain & Daily precipitation as rain. \\
\hline snowfall & Daily precipitation as snow. \\
\hline snowcover & Water-equivalent depth of snow cover. \\
\hline snowmelt & Daily snowmelt. \\
\hline sublimation & Daily sublimation. \\
\hline pet3 & $\begin{array}{l}\text { Approximate potential evapotranspiration estimated on the basis of vegetation cover, } \\
\text { bare-soil area, and Priestley-Taylor } \alpha \text { coefficients. }\end{array}$ \\
\hline pet2 & Potential evapotranspiration adjusted for cloudy days. \\
\hline pet & Potential evapotranspiration adjusted for cloudy days and sublimation. \\
\hline et & Total actual evapotranspiration from soil zone. \\
\hline delta-storage1 & Change in water content for all six soil layers of model cell in first step of flow routing. \\
\hline delta-storage 2 & $\begin{array}{l}\text { Change in water content for all six soil layers of model cell in second step of } \\
\text { flow routing. }\end{array}$ \\
\hline delta-storage & Total change in water content for all six soil layers of model cell for current day. \\
\hline runoff & Runoff during first step of flow routing. \\
\hline net-infil1 & Net infiltration in first step of flow routing. \\
\hline net-infil2 & Net infiltration in second step of flow routing. \\
\hline net-infil3 & Total net infiltration. \\
\hline runon-infil1 & Water-content change caused by infiltration of runoff for all six layers. \\
\hline sw-inflow & Infiltration into soil for second step of flow-routing algorithm. \\
\hline sw-outflow & Runoff during second step of flow routing. \\
\hline soilmm1, ..., soilmm5 & Soil-water content for layers $1-5$. \\
\hline soilvwc1, ..., soilvwc5 & Dimensionless volumetric soil-water content for layers $1-5$. \\
\hline et1, ..., et5 & $\begin{array}{l}\text { Evapotranspiration from soil layers } 1-2 \text { (et1 and et2) and evaporation from soil } \\
\text { layers 3-5 (et3, et4, and et5). }\end{array}$ \\
\hline flux1, ..., flux 5 & Flow from overlying to underlying layer in first step of flow routing. \\
\hline fluxr1, ..., fluxr5 & Flow from overlying to underlying layer in second step of flow routing. \\
\hline rockmm1 & Rock-water content. \\
\hline rockvwc1 & Dimensionless volumetric rock-water content for layer 6. \\
\hline et6 & Evaporation from rock layer. \\
\hline c-day-balance & Mass-balance check for each grid cell. \\
\hline
\end{tabular}


Table 1-4. Definitions for column headings printed to the daily output file for specific grid cells.

[Water-budget terms are in millimeters unless otherwise noted]

\begin{tabular}{|c|c|}
\hline Column heading & Definition \\
\hline daynum & Sequential day number in simulation. \\
\hline year & Year. \\
\hline mo & Month. \\
\hline md & Day of month. \\
\hline yd & Day of year. \\
\hline temp & Average daily air temperature. \\
\hline swinflow & Surface-water inflow from upstream basins. \\
\hline precip & Daily precipitation. \\
\hline rain & Daily precipitation as rain. \\
\hline snowfall & Daily precipitation as snow. \\
\hline snowpack & Water-equivalent depth of snow cover. \\
\hline snowmelt & Daily snowmelt. \\
\hline sublimation & Daily sublimation. \\
\hline pet3 & $\begin{array}{l}\text { Approximate potential evapotranspiration estimated on the basis of } \\
\text { vegetation cover, bare-soil area, and Priestley-Taylor } \alpha \text { coefficients. }\end{array}$ \\
\hline pet2 & Total unadjusted potential evapotranspiration. \\
\hline pet & Potential evapotranspiration adjusted for cloudy days and sublimation. \\
\hline et & Total actual evapotranspiration from soil zone. \\
\hline delta-storage1 & $\begin{array}{l}\text { Change in water content for all six soil layers of model cell in first step } \\
\text { of flow routing. }\end{array}$ \\
\hline delta-storage 2 & $\begin{array}{l}\text { Change in water content for all six soil layers of model cell in second } \\
\text { stop of flow routing. }\end{array}$ \\
\hline delta-storage & Sum of delta-storage 1 and delta-storage 2. \\
\hline runon & Total infiltration of run-on for both steps of flow-routing algorithm. \\
\hline layer1mm, ..., layer6mm & Water content for each model layer. \\
\hline layer1wc, ..., layer6wc & Dimensionless volumetric water content for each model layer. \\
\hline layer1et, ..., layer6et & $\begin{array}{l}\text { Evapotranspiration from model layers } 1 \text { and } 2 \text { (layer1et and } \\
\text { layer2et) and transpiration from layers } 3 \text { through } 6 \text { (layer3et } \\
\text { through layer6et). }\end{array}$ \\
\hline layer1drain, ..., layer5drain & $\begin{array}{l}\text { Flow from overlying to underlying model layer in first step of } \\
\text { flow routing. }\end{array}$ \\
\hline rundrain1, ..., rundrain5 & $\begin{array}{l}\text { Flow from overlying to underlying model layer in second step of } \\
\text { flow routing. }\end{array}$ \\
\hline runoff & Runoff during first step of flow routing. \\
\hline net-infil1 & Net infiltration in first step of flow-routing algorithm. \\
\hline net-infil2 & Net infiltration in second step of flow-routing algorithm. \\
\hline net-infil3 & Total net infiltration. \\
\hline run-infil & Water-content change caused by infiltration of run-on for all six layers. \\
\hline sw-inflow & Infiltration into soil in second step of flow-routing algorithm. \\
\hline sw-outflow & Runoff during second step of flow routing. \\
\hline tot-outflow & Total runoff estimated for both steps of the flow-routing algorithm. \\
\hline c-day-balance & Mass-balance check for each grid cell. \\
\hline
\end{tabular}


Table 1-5. Definitions for column headings printed to the annual and average annual output files for all grid cells.

[Water-budget terms are in millimeters unless otherwise noted. In the variable definitions, annual indicates an averaging interval of one year, whereas average annual indicates an averaging interval greater than one year]

\begin{tabular}{|c|c|}
\hline Column heading & Definition \\
\hline cellcode & Grid-cell (node) number. \\
\hline easting & Grid-cell east-west coordinate. \\
\hline northing & Grid-cell north-south coordinate. \\
\hline temp & Average daily air temperature, in degrees Celsius. \\
\hline Swinflow & Annual or average annual surface-water inflow from upstream basins. \\
\hline precip & Annual or average annual precipitation. \\
\hline rain & Annual or average annual precipitation as rain. \\
\hline snowfall & Annual or average annual precipitation as snow. \\
\hline snowcover & Annual or average annual water-equivalent depth of snow cover. \\
\hline snowmelt & Annual or average annual snowmelt. \\
\hline sublimation & Annual or average annual sublimation. \\
\hline pet3 & $\begin{array}{l}\text { Annual or average annual approximate potential evapotranspiration estimated } \\
\text { on the basis of vegetation cover, bare-soil area, and Priestley-Taylor } \alpha \\
\text { coefficients. }\end{array}$ \\
\hline pet2 & Annual or average annual total unadjusted potential evapotranspiration. \\
\hline pet & $\begin{array}{l}\text { Annual or average annual potential evapotranspiration adjusted for cloudy } \\
\text { days and sublimation. }\end{array}$ \\
\hline et & Annual or average annual total actual evapotranspiration from soil zone. \\
\hline delta-storage1 & $\begin{array}{l}\text { Annual or average annual change in water content for all six soil layers of } \\
\text { model cell in first step of flow routing. }\end{array}$ \\
\hline net-infil1 & Annual or average annual net infiltration in first step of flow routing. \\
\hline net-infil2 & Annual or average annual net infiltration in second step of flow routing. \\
\hline net-infil3 & Annual or average annual total net infiltration. \\
\hline runoff & Annual or average annual runoff during first step of flow routing. \\
\hline run-infil & $\begin{array}{l}\text { Annual or average annual water-content change caused by infiltration of } \\
\text { run-on for all six layers. }\end{array}$ \\
\hline run-on & Annual or average annual runoff for second step of flow-routing algorithm. \\
\hline mass-balance & Annual or average annual mass-balance error term for net infiltration. \\
\hline
\end{tabular}


Table 1-6. Definitions for column headings printed to the daily and cumulative output file for the last successful day of a simulation.

[Water-budget terms are in millimeters unless otherwise noted]

\begin{tabular}{|c|c|}
\hline Column heading & Definition \\
\hline daynum & Sequential day number in simulation. \\
\hline year & Year. \\
\hline easting & Grid-cell east-west coordinate. \\
\hline northing & Grid-cell north-south coordinate. \\
\hline row & Row number of grid cell. \\
\hline col & Column number of grid cell. \\
\hline snowmm & Water-equivalent depth of snow cover for cell for last successful day of simulation. \\
\hline soilmm1, ..., soilmm5 & Soil-water content for layers $1-5$ of cell for last successful day of simulation. \\
\hline rockmm & Rock-water content of cell for last successful day of simulation. \\
\hline aappt & Cumulative precipitation at cell through last successful day of simulation. \\
\hline aarain & Cumulative precipitation as rain at cell through last successful day of simulation. \\
\hline aasnow & Cumulative precipitation as snow at cell through last successful day of simulation. \\
\hline aasncv & $\begin{array}{l}\text { Cumulative water-equivalent depth of snow cover at cell through last successful } \\
\text { day of simulation. }\end{array}$ \\
\hline aamelt & Cumulative snowmelt at cell through last successful day of simulation. \\
\hline aasubl & Cumulative sublimation at cell through last successful day of simulation. \\
\hline aapet & $\begin{array}{l}\text { Cumulative potential evapotranspiration adjusted for cloudy days and sublimation } \\
\text { for cell through last successful day of simulation. }\end{array}$ \\
\hline aatet & $\begin{array}{l}\text { Cumulative total evapotranspiration from soil zone for cell through last successful } \\
\text { day of simulation. }\end{array}$ \\
\hline aadsw1 & $\begin{array}{l}\text { Cumulative change in water content for all six soil layers in first step of flow rout- } \\
\text { ing at cell through last successful day of simulation. }\end{array}$ \\
\hline aadsw2 & $\begin{array}{l}\text { Cumulative change in water content for all six soil layers in second step of flow } \\
\text { routing at cell through last successful day of simulation. }\end{array}$ \\
\hline aainfr & $\begin{array}{l}\text { Cumulative water-content change caused by infiltration of run-on for all six layers } \\
\text { of cell through last successful day of simulation. }\end{array}$ \\
\hline aainf1 & $\begin{array}{l}\text { Cumulative net infiltration in first step of flow routing at cell through last success- } \\
\text { ful day of simulation. }\end{array}$ \\
\hline aainf2 & $\begin{array}{l}\text { Cumulative net infiltration in second step of flow routing at cell through last suc- } \\
\text { cessful day of simulation. }\end{array}$ \\
\hline aaoff & $\begin{array}{l}\text { Cumulative runoff in first step of flow routing at cell through last successful day of } \\
\text { simulation. }\end{array}$ \\
\hline aarun & $\begin{array}{l}\text { Cumulative runoff in second step of flow routing at cell through last successful day } \\
\text { of simulation. }\end{array}$ \\
\hline
\end{tabular}


Table 1-7. Definitions for column headings printed to the daily output file for the spatially averaged water-budget components.

[Water-budget terms are average values for all active grid cells, in millimeters unless otherwise noted]

\begin{tabular}{|c|c|}
\hline Column heading & Definition \\
\hline daynum & Sequential day number in simulation. \\
\hline year & Year. \\
\hline mo & Month. \\
\hline md & Day of month. \\
\hline yd & Day of year. \\
\hline temp & Daily air temperature. \\
\hline nrun3 & $\begin{array}{l}\text { Number of grid cells generating runoff (either Hortonian- or Dunnian-type runoff) for a given daily } \\
\text { time step. }\end{array}$ \\
\hline swinflow & Surface-water inflow from upstream basins. \\
\hline precip & Daily precipitation. \\
\hline rain & Daily precipitation as rain. \\
\hline snowfall & Daily precipitation as snow. \\
\hline snowcover & Water-equivalent depth of snow cover. \\
\hline snowmelt & Daily snowmelt. \\
\hline sublimation & Daily sublimation. \\
\hline pet3 & $\begin{array}{l}\text { Approximate potential evapotranspiration estimated on the basis of vegetation cover, bare-soil area, } \\
\text { and Priestley-Taylor } \alpha \text { coefficients. }\end{array}$ \\
\hline pet2 & Unadjusted potential evapotranspiration. \\
\hline pet & Potential evapotranspiration adjusted for cloudy days and sublimation. \\
\hline et & Total actual evapotranspiration from soil zone. \\
\hline delta-storage1 & Change in water content for all six soil layers of model cell in first step of flow routing. \\
\hline delta-storage 2 & Change in water content for all six soil layers of model cell in second step of flow routing. \\
\hline delta-storage & Total change in water content for all six soil layers of model cell for current day. \\
\hline layer1mm, ..., layer6mm & Water content for each model layer. \\
\hline layer1wc, ..., layer6wc & Water content for each model layer divided by the average layer thickness, dimensionless. \\
\hline lay1etday, ..., lay6etday & Evapotranspiration for each model layer. \\
\hline layer1drain, ..., layer6drain & $\begin{array}{l}\text { Flow from one model layer to the underlying layer in first step of flow routing; layer6drain is } \\
\text { net infiltration. }\end{array}$ \\
\hline rundrain1, ..., rundrain6 & $\begin{array}{l}\text { Flow from one model layer to the underlying layer in second step of flow routing; rundrain6 is } \\
\text { net infiltration. }\end{array}$ \\
\hline runoff & Runoff during first step of flow routing. \\
\hline net-infil1 & Net infiltration in first step of flow routing. \\
\hline net-infil2 & Net infiltration in second step of flow routing. \\
\hline net-infil3 & Total net infiltration. \\
\hline rinfday & Infiltrated run-on from previous day. \\
\hline runonday & Total infiltration to soil in second step of flow routing. \\
\hline inflow0 & Inflow to last active grid cell in basin in second step of flow routing. \\
\hline totout2 & Runoff from grid cell at basin outflow. \\
\hline outflow0 & Outflow from last active grid cell in basin in second step of flow routing. \\
\hline swgainday & Net surface-water gain (inflow minus outflow) within the basin for the day. \\
\hline it & Number of iterations in second step of the flow routing. \\
\hline discharge0 & Outflow from last active grid cell in basin in second step of flow routing, in cubic meters of water. \\
\hline discharge1 & Runoff at basin outflow cell, in cubic meters of water. \\
\hline discharge2 & Outflow from last active grid cell in basin, in cubic meters of water. \\
\hline g-day-balance & Mass-balance check for each daily time step. \\
\hline
\end{tabular}


Table 1-8. Definitions for column headings printed to the monthly and annual output files for all grid cells.

[Water-budget terms are in millimeters unless otherwise noted]

\begin{tabular}{|c|c|}
\hline Column heading & Definition \\
\hline year & Year. \\
\hline mo & Month. \\
\hline md & Day of month. \\
\hline yd & Day of year. \\
\hline nd & Sequential day number in simulation. \\
\hline precip & Total precipitation. \\
\hline rain & Total precipitation as rain. \\
\hline snow & Total precipitation as snow. \\
\hline snowpack & Total water-equivalent depth of snow cover. \\
\hline snowmelt & Total snowmelt. \\
\hline sublimation & Total sublimation. \\
\hline pet3 & $\begin{array}{l}\text { Approximate potential evapotranspiration estimated on the basis of vegetation cover, } \\
\text { bare-soil area, and Priestley-Taylor } \alpha \text { coefficients. }\end{array}$ \\
\hline pet2 & Total unadjusted potential evapotranspiration for the month or year. \\
\hline pet0 & Total potential evapotranspiration adjusted for cloudy days for the month or year. \\
\hline pet & $\begin{array}{l}\text { Total potential evapotranspiration adjusted for cloudy days and sublimation for the month } \\
\text { or year. }\end{array}$ \\
\hline et & Total actual evapotranspiration from soil zone for the month or year. \\
\hline delta-storage & $\begin{array}{l}\text { Total change in water content for all six layers of model cell in first step of flow routing } \\
\text { for the month or year. }\end{array}$ \\
\hline net-infil1 & Total net infiltration in first step of flow routing. \\
\hline net-infil2 & Total net infiltration in second step of flow routing. \\
\hline net-infil3 & Total net infiltration. \\
\hline runoff & Total runoff during first step of flow routing. \\
\hline run-infil & Total infiltrated run-on from previous day. \\
\hline outflow & Total flow at outflow cell of basin. \\
\hline mass-bal & Total mass-balance error for the year (not printed for the monthly output). \\
\hline
\end{tabular}


Table 1-9. Definitions of variables printed to the average annual output file for each grid cell.

[Water-budget terms are in millimeters per year unless otherwise noted]

\begin{tabular}{|c|c|}
\hline Column heading & Definition \\
\hline cellcode & Grid-cell (node) number. \\
\hline easting & Grid-cell east-west coordinate. \\
\hline northing & Grid-cell north-south coordinate. \\
\hline ndays & Number of days in averaging period. \\
\hline elev & Land-surface elevation. \\
\hline temp & Average annual air temperature. \\
\hline swinflw & Average annual surface-water inflow from upstream basins. \\
\hline precip & Average annual precipitation. \\
\hline rain & Average annual precipitation as rain. \\
\hline snowfall & Average annual precipitation as snow. \\
\hline snowcover & Average annual water-equivalent depth of snow cover. \\
\hline snowmelt & Average annual snowmelt. \\
\hline sublimation & Average annual sublimation. \\
\hline pet3 & $\begin{array}{l}\text { Average annual approximate potential evapotranspiration estimated on the } \\
\text { basis of vegetation cover, bare-soil area, and Priestley-Taylor } \alpha \text { coefficients. }\end{array}$ \\
\hline pet2 & Average annual unadjusted potential evapotranspiration. \\
\hline pet & $\begin{array}{l}\text { Average annual potential evapotranspiration adjusted for cloudy days and } \\
\text { sublimation. }\end{array}$ \\
\hline et & Average annual total actual evapotranspiration from soil zone. \\
\hline delta-storage1 & $\begin{array}{l}\text { Average annual change in water content for all six soil layers of model cell in } \\
\text { first step of flow routing. }\end{array}$ \\
\hline delta-storage 2 & $\begin{array}{l}\text { Average annual change in water content for all six soil layers of model cell in } \\
\text { second step of flow routing. }\end{array}$ \\
\hline runoff & Average annual runoff during first step of flow routing. \\
\hline net-infil1 & Average annual net infiltration in first step of flow routing. \\
\hline net-infil2 & Average annual net infiltration in second step of flow routing. \\
\hline net-infil3 & Average annual total net infiltration. \\
\hline runon-infil1 & $\begin{array}{l}\text { Average annual water-content change caused by infiltration of run-on for all } \\
\text { six layers. }\end{array}$ \\
\hline Sw-inflow & Average annual run-on. \\
\hline sw-outflow & Average annual runoff during second step of flow routing. \\
\hline total-outflow & Average annual total runoff. \\
\hline run-on(cfs) & Average annual runoff for second step of flow routing, in cubic feet per second. \\
\hline run-on(cmd) & Average annual runoff for second step of flow routing, in cubic meters per day. \\
\hline c-run-balance & Average annual mass-balance check for each grid cell. \\
\hline
\end{tabular}





\section{Appendix 2. Programmers' Documentation}

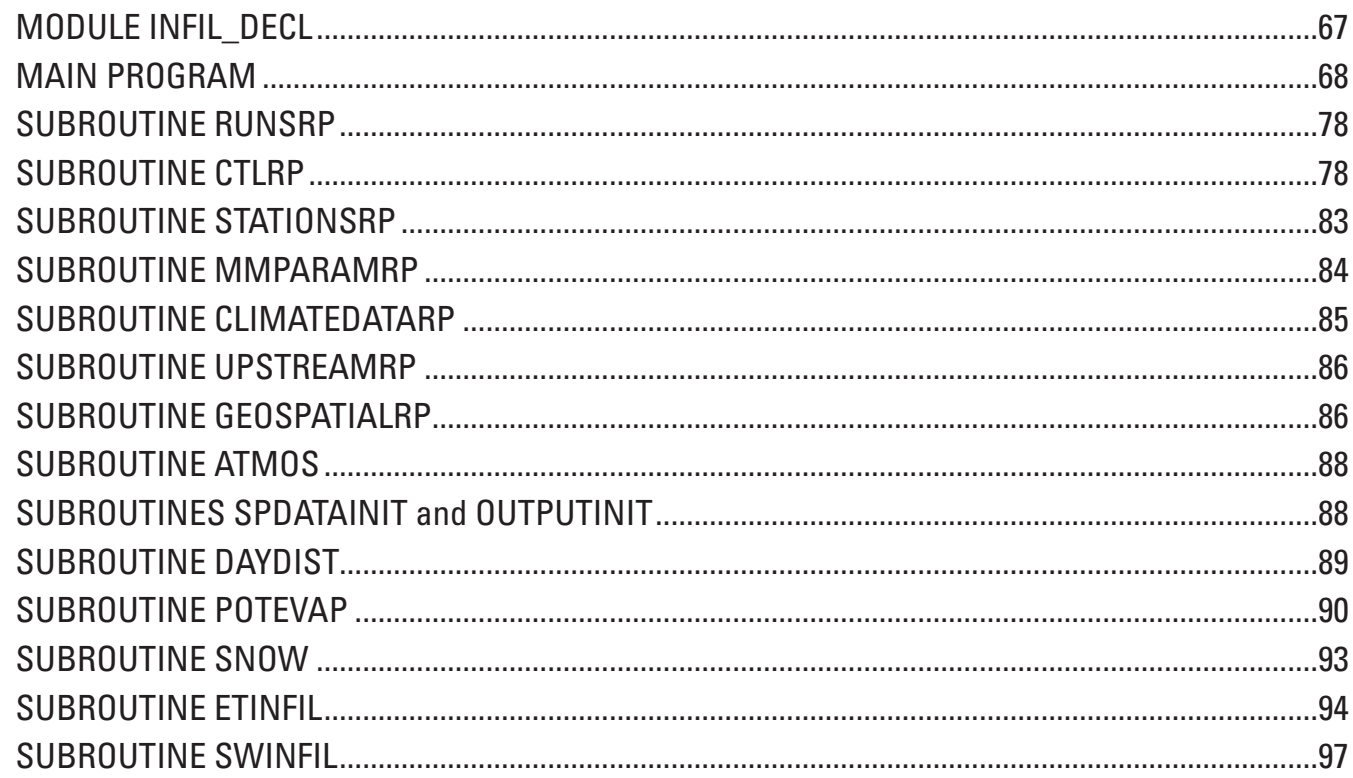

\section{Tables}

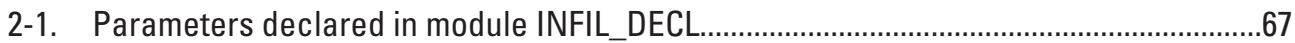

2-2. Miscellaneous variables used in MAIN program .........................................................68

2-3. Variables related to volumetric balances in MAIN program ..........................................70

2-4. Variables related to daily volumetric balances in postprocessing phase of



2-5. Variables related to total monthly volumetric balances in postprocessing phase of

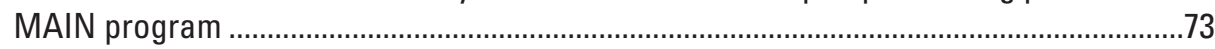

2-6. Variables related to total annual volumetric balances in postprocessing phase

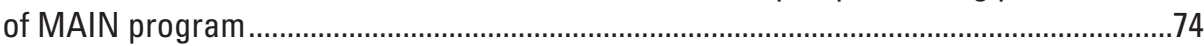

2-7. Variables related to average annual volumetric balances for each cell in postprocessing phase of MAIN program....

2-8. Variables related to long-term average annual volumetric balances for each location during averaging period of MAIN program .......................................................76

2-9. Variables related to global average annual volumetric balances for all cells in the simulation domain during averaging period of MAIN program ..................................77

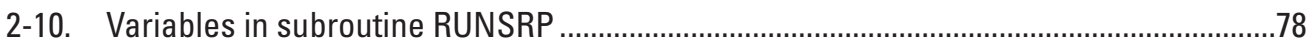

2-11. Variables in subroutine CTLRP read from the Simulation-Control File ..............................78

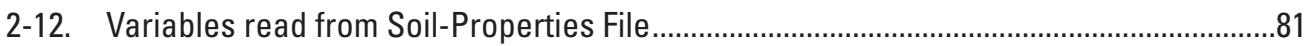

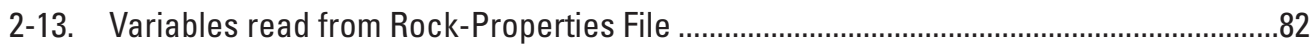

2-14. Variables read from Vegetation-Properties File .........................................................82

2-15. Variables read from Monthly Atmospheric-Parameters File ...........................................83

2-16. Variables in subroutine STATIONSRP .........................................................................83 
2-17. Variables in subroutine MMPARAMRP ...............................................................................84

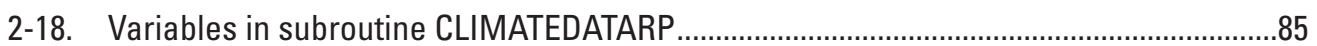

2-19. Variables in subroutine UPSTREAMRP ............................................................................ 86

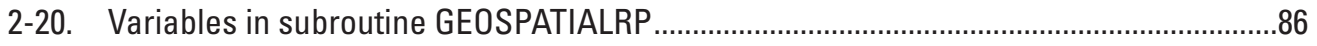

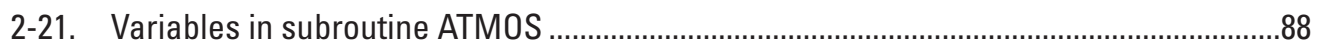

2-22. Variables in subroutines SPDATAINIT and OUTPUTINIT not defined previously............88

2-23. Variables in subroutine DAYDIST ........................................................................................89

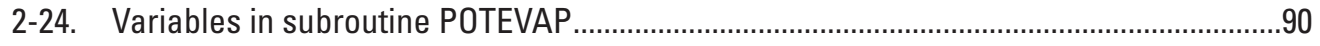

2-25. Variables in subroutine SNOW......................................................................................93

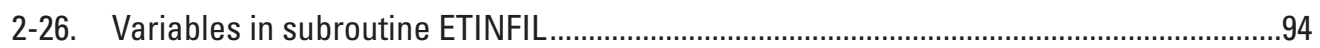

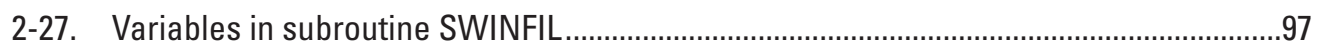


This appendix provides brief descriptions of each of the major components of the INFIL3.0 code, as well as definitions of the major program variables used in each program component. INFIL3.0 is written in the FORTRAN-90 computer-programming language.

\section{MODULE INFIL_DECL}

Module INFIL_DECL is used to declare variables and parameters that are shared among the MAIN program and subroutines. Several parameters that are declared in this module are defined in table 2-1. The remaining variables in the module are defined in the sections below for the MAIN program and each of the subroutines.

Table 2-1. Parameters declared in module INFIL_DECL.

\begin{tabular}{|c|c|c|}
\hline Variable name & Size & Description \\
\hline mxcells & 60,005 & Maximum number of grid cells in a simulation. \\
\hline mxgridind & 3,350 & Maximum number of row or column grid indices in a simulation. \\
\hline mxprop & 800 & Maximum number of rock or soil types in a simulation. \\
\hline mxstations & 250 & Maximum number of climate stations in a simulation. \\
\hline vegcodeub & 10,000 & Upper bound on vegetation code indice. \\
\hline dr & scalar & Degrees to radians conversion; set to 0.0174533 . \\
\hline rd & scalar & Radians to degrees conversion; set to 57.29579 . \\
\hline pi & scalar & The number pi; set to 3.141592654 . \\
\hline
\end{tabular}




\section{MAIN PROGRAM}

The MAIN program controls the order in which the subroutines are executed, as well as processing and writing of simulation results. Miscellaneous variables used in the MAIN program are defined in table 2-2, whereas water-budget terms are defined in tables 2-3 through 2-9.

Table 2-2. Miscellaneous variables used in MAIN program.

[C* $\mathrm{n}$ in size column indicates a character variable of $n$ characters]

\begin{tabular}{|c|c|c|}
\hline Variable name & Size & Description \\
\hline nr & scalar & Counter for number of simulations. \\
\hline nruns & scalar & Total number of simulations. \\
\hline initopt & scalar & Flag that determines how initial soil-water content conditions will be set. \\
\hline ndavg & scalar & Number of days in averaging period. \\
\hline $\mathbf{j}$ & scalar & Time step counter. \\
\hline yrstart & scalar & Simulation start year. \\
\hline mostart & scalar & Simulation start month. \\
\hline dystart & scalar & Simulation start day. \\
\hline dyend & scalar & Simulation end day. \\
\hline istart & scalar & Sequential day number of simulation start time. \\
\hline iend & scalar & Sequential day number of simulation end time. \\
\hline yrstart1 & scalar & Simulation start year for calculation of simulation averages. \\
\hline mostart1 & scalar & Simulation start month for calculation of simulation averages. \\
\hline dystart1 & scalar & Simulation start day for calculation of simulation averages. \\
\hline yrend1 & scalar & Simulation end year for calculation of simulation averages. \\
\hline moend1 & scalar & Simulation end month for calculation of simulation averages. \\
\hline iwat & mxcells & $\begin{array}{l}\text { Downstream grid identifier to which runoff is directed from current cell (iwat }=-3 \text { indicates the } \\
\text { outflow cell from the basin). }\end{array}$ \\
\hline monthold & scalar & Current month of simulation. \\
\hline nupstream & scalar & $\begin{array}{l}\text { Number of upstream basins contributing surface-water inflow. A maximum of } 5 \text { upstream basins } \\
\text { can be specified. }\end{array}$ \\
\hline iupstream & 5 & $\begin{array}{l}\text { Last value of cellcode that is read from each upgeoinp file. All values in the iupstream array } \\
\text { should be equal; otherwise, the program will stop. }\end{array}$ \\
\hline cellcode & mxcells & Location identifier for each grid cell. \\
\hline
\end{tabular}


Table 2-2. Miscellaneous variables used in MAIN program.-Continued

[C* $\mathrm{n}$ in size column indicates a character variable of $n$ characters]

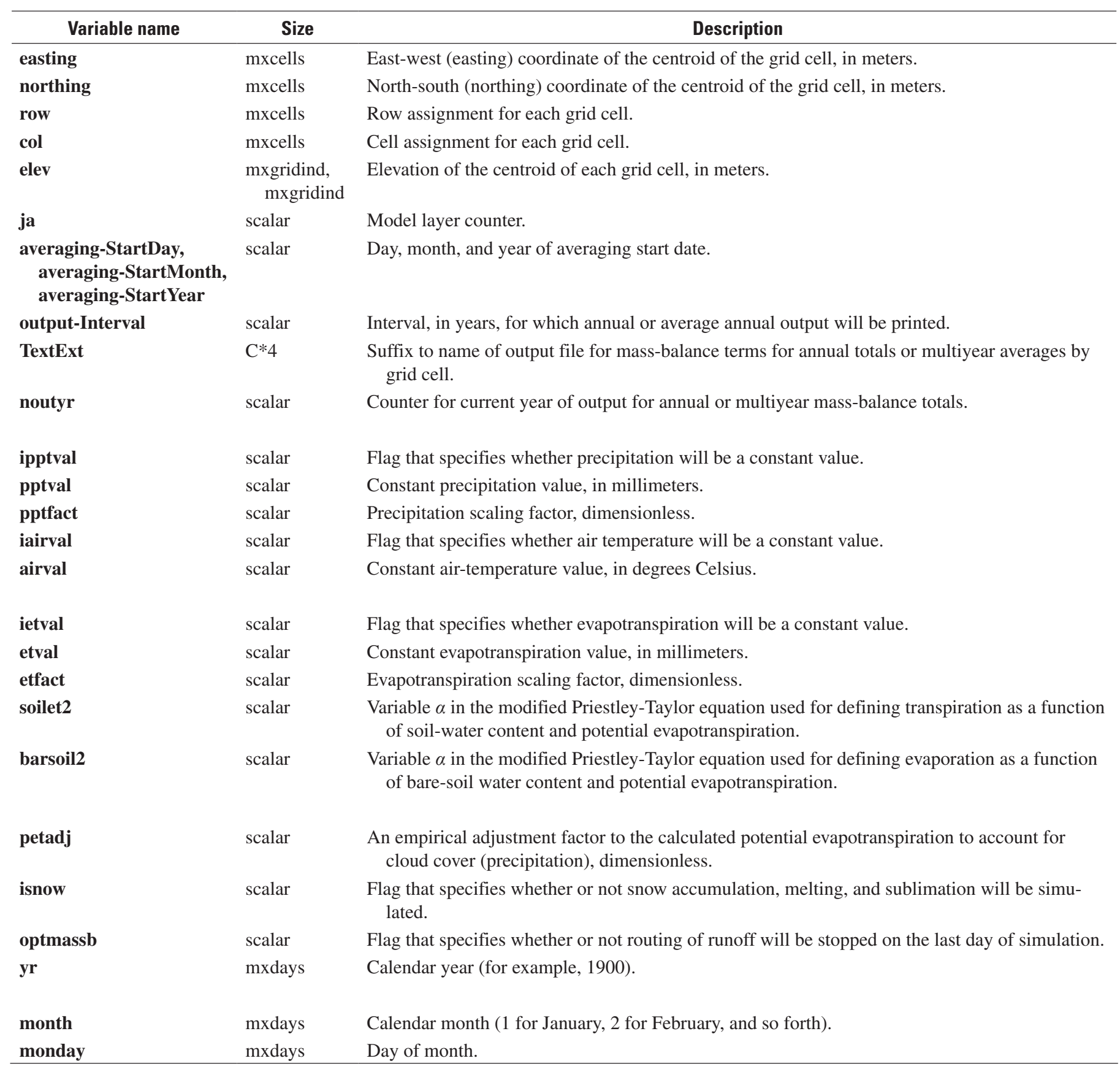


Table 2-3. Variables related to volumetric balances in MAIN program.

\begin{tabular}{|c|c|c|}
\hline Variable name & Size & Description \\
\hline inflow0 & scalar & $\begin{array}{l}\text { Daily inflow to last active grid cell in basin due to second step of flow routing, in millimeters of water } \\
\text { over the basin. }\end{array}$ \\
\hline outflow0 & scalar & $\begin{array}{l}\text { Daily outflow from last active grid cell in basin due to second step of flow routing, in millimeters of } \\
\text { water over the basin. }\end{array}$ \\
\hline outflow2 & scalar & Total daily outflow from last active grid cell in basin, in millimeters of water over the basin. \\
\hline swgainday & scalar & Net surface-water gain within the basin for the day, in millimeters. \\
\hline swinflw & mxdays, 5 & Surface-water flow value from upstream basin, in millimeters. \\
\hline flowout & $\begin{array}{l}\text { 0:mxgridind, } \\
\text { 0:mxgridind }\end{array}$ & Runoff from each grid cell for first step of flow routing, in millimeters. \\
\hline totout & $\begin{array}{l}\text { 0:mxgridind, } \\
\text { 0:mxgridind }\end{array}$ & Total runoff from each grid cell for second step of flow routing, in millimeters. \\
\hline totout2 & scalar & Runoff from grid cell at basin outflow, in millimeters. \\
\hline totout3 & scalar & Runoff from grid cell at basin outflow divided by number of grid cells, in millimeters. \\
\hline vegcover0 & $\begin{array}{l}\text { vegcodelb: } \\
\text { vegcodeub }\end{array}$ & Vegetation cover for vegetation type vegmap (specified as a percentage, such as 50.0). \\
\hline avglaythck & 10 & Average layer thickness for each of the six model layers, in meters. \\
\hline cdepth & 6, mxcells & Layer thickness for layers 1 through 6 , in meters. \\
\hline discharge 0 & scalar & $\begin{array}{l}\text { Daily outflow from last active grid cell in basin due to second step of flow routing, in cubic meters } \\
\text { of water. }\end{array}$ \\
\hline discharge1 & scalar & Daily runoff from grid cell at basin outflow, in cubic meters of water. \\
\hline totoutflow & mxcells & Total runoff from each grid cell for both steps of the flow-routing algorithm, in millimeters. \\
\hline runmassb1 & mxcells & $\begin{array}{l}\text { Mass-balance error term for net infiltration equation that includes changes in water content of soil zone } \\
\text { for second step of the flow-routing algorithm, in millimeters. }\end{array}$ \\
\hline totupflow & scalar & Total surface-water flow from upstream basins, in millimeters. \\
\hline pptloc & mxcells & Precipitation for each cell, in millimeters. \\
\hline pptloc00 & scalar & Precipitation for each cell, in millimeters. \\
\hline rain & mxcells & Precipitation as rain for each cell, in millimeters. \\
\hline snowfall & mxcells & Precipitation as snow for each cell, in millimeters. \\
\hline snowmm & mxcells & Water-equivalent depth of snow for each cell, in millimeters. \\
\hline meltmm & mxcells & Snowmelt for each cell, in millimeters. \\
\hline sublim & mxcells & Sublimation for each cell, in millimeters. \\
\hline avgairt & mxcells & Average air temperature for each cell, in degrees Celsius. \\
\hline dsoilmm1 & mxcells & $\begin{array}{l}\text { Change in water content for all six soil layers due to first step of flow routing for each cell, } \\
\text { in millimeters. }\end{array}$ \\
\hline
\end{tabular}


Table 2-3. Variables related to volumetric balances in MAIN program.-Continued

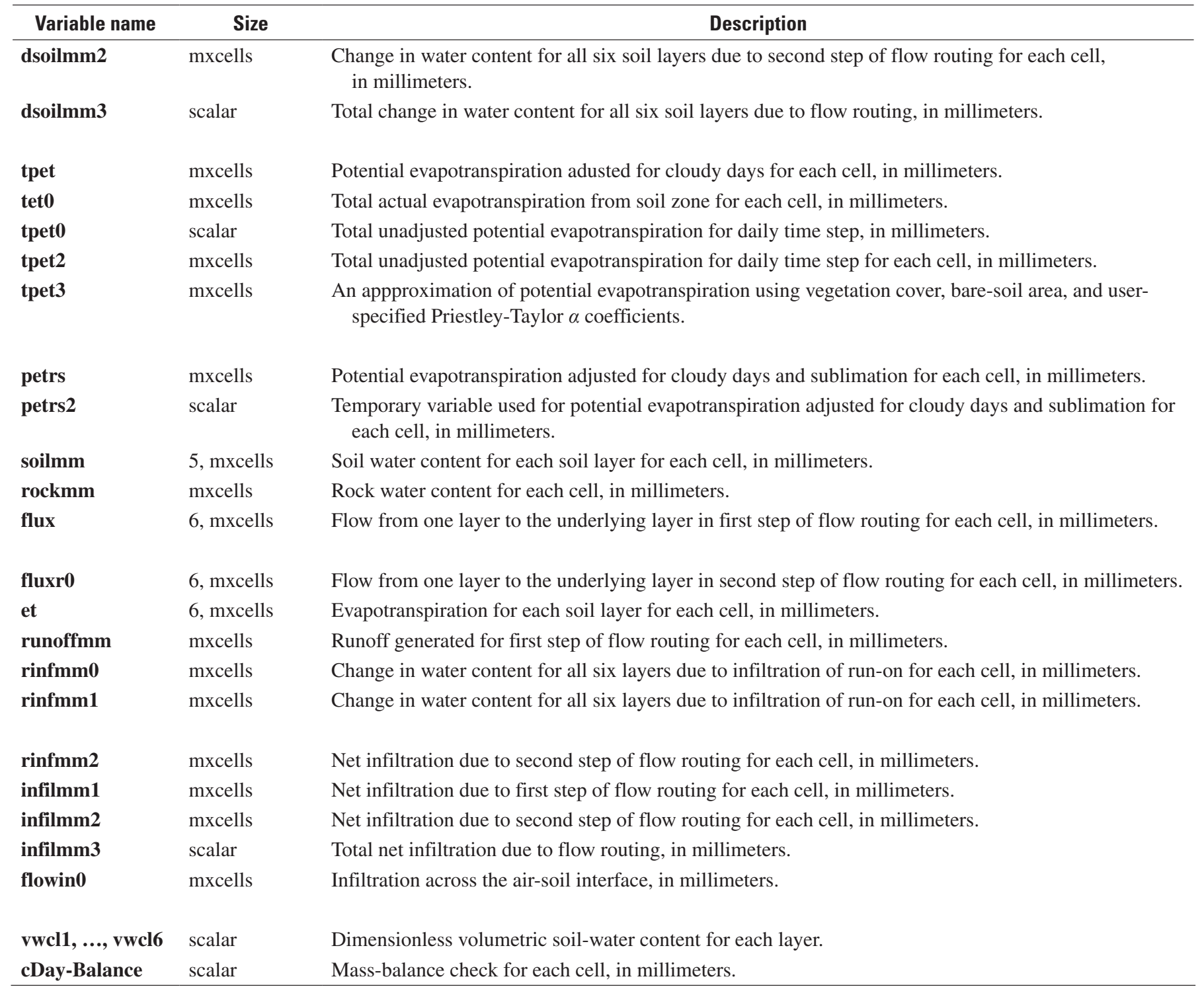


Table 2-4. Variables related to daily volumetric balances in postprocessing phase of MAIN program.

\begin{tabular}{|c|c|c|}
\hline Variable name & Size & Description \\
\hline upflwday & scalar & Daily total surface-water flow from upstream basins, in millimeters. \\
\hline pptday & scalar & Daily precipitation for all cells, in millimeters. \\
\hline snowday & scalar & Daily precipitation as snow for all cells, in millimeters. \\
\hline sncvday & scalar & Daily water-equivalent depth of snow for all cells, in millimeters. \\
\hline sublday & scalar & Daily sublimation for all cells, in millimeters. \\
\hline atday & scalar & Daily air temperature for all cells, in degrees Celsius. \\
\hline petday & scalar & Daily potential evapotranspiration adjusted for cloudy days for all cells, in millimeters. \\
\hline pet2day & scalar & Daily unadjusted potential evapotranspiration for daily time step for all cells, in millimeters. \\
\hline tetday & scalar & Total daily actual evapotranspiration from soil zone, in millimeters. \\
\hline tetday0 & scalar & Daily total actual evapotranspiration from soil zone for all cells, in millimeters. \\
\hline soilday 1 & scalar & $\begin{array}{l}\text { Daily change in water content for all six model layers due to first step of flow routing for all cells, } \\
\text { in millimeters. }\end{array}$ \\
\hline soilday 2 & scalar & $\begin{array}{l}\text { Daily change in water content for all six model layers due to second step of flow routing for all cells, } \\
\text { in millimeters. }\end{array}$ \\
\hline soilday3 & scalar & Total daily change in water content for all six model layers for all cells, in millimeters. \\
\hline $\begin{array}{l}11 \text { mmday, ...., } \\
\text { 15mmday }\end{array}$ & scalar & Daily soil water content for each soil layer for all cells, in millimeters. \\
\hline $\begin{array}{l}\text { l1rundrn, .... } \\
\text { l6rundrn }\end{array}$ & scalar & Daily flow from one layer to the underlying layer in second step of flow routing for all cells, in millimeters. \\
\hline runday & scalar & Daily runoff generated for first step of flow routing for all cells, in millimeters. \\
\hline rinfday & scalar & Daily change in water content for all six layers due to infiltration of run-on for all cells, in millimeters. \\
\hline rinfday 2 & scalar & Infiltrated run-on from previous day, in millimeters. \\
\hline infrday & scalar & Daily net infiltration due to second step of flow routing for all cells, in millimeters. \\
\hline inf1day & scalar & Daily net infiltration due to first step of flow routing for all cells, in millimeters. \\
\hline $\inf 2$ day & scalar & Daily net infiltration due to second step of flow routing for all cells, in millimeters. \\
\hline inf3day & scalar & Total daily net infiltration for all cells, in millimeters. \\
\hline runonday & scalar & Daily infiltration across air-soil interface for second step of flow-routing algorithm, in millimeters. \\
\hline totout4 & scalar & Daily flow at outflow cell of basin, in millimeters of water over the entire basin. \\
\hline cfsday & scalar & Daily flow at outflow cell of basin, in cubic feet per second from the entire basin. \\
\hline gDay-Balance & scalar & Mass-balance check for each daily time step, in millimeters. \\
\hline
\end{tabular}


Table 2-5. Variables related to total monthly volumetric balances in postprocessing phase of MAIN program.

\begin{tabular}{|c|c|c|}
\hline Variable name & Size & Description \\
\hline pptmo & scalar & Total precipitation for all cells for the month, in millimeters. \\
\hline rainmo & scalar & Total precipitation as rain for all cells for the month, in millimeters. \\
\hline sncvmo & scalar & Total water-equivalent depth of snow for all cells for the month, in millimeters. \\
\hline meltmo & scalar & Total snowmelt for all cells for the month, in millimeters. \\
\hline atmo & scalar & Total air temperature for all cells for the month, in degrees Celsius. \\
\hline petmo & scalar & Total potential evapotranspiration adjusted for cloudy days for all cells for the month, in millimeters. \\
\hline pet $2 \mathrm{mo}$ & scalar & Total unadjusted potential evapotranspiration for daily time step for all cells for the month, in millimeters. \\
\hline pet3mo & scalar & $\begin{array}{l}\text { Total approximation of potential evapotranspiration using vegetation cover, bare-soil area, and user-specified } \\
\text { Priestley-Taylor coefficient } \alpha \text { coefficients for all cells for the month, in millimeters. }\end{array}$ \\
\hline tetmo & scalar & Total actual evapotranspiration from soil zone for the month, in millimeters. \\
\hline dswmo1 & scalar & $\begin{array}{l}\text { Total change in water content for all six model layers due to first step of flow routing for all cells for the month, } \\
\text { in millimeters. }\end{array}$ \\
\hline dswmo2 & scalar & $\begin{array}{l}\text { Total change in water content for all six model layers due to second step of flow routing for all cells for the } \\
\text { month, in millimeters. }\end{array}$ \\
\hline inf1mo & scalar & Total net infiltration due to first step of flow routing for all cells for the month, in millimeters. \\
\hline inf2mo & scalar & Total net infiltration due to second step of flow routing for all cells for the month, in millimeters. \\
\hline inf3mo & scalar & Total daily net infiltration for all cells for the month, in millimeters. \\
\hline rinfmo & scalar & Total infiltrated run-on from previous day for the month, in millimeters. \\
\hline
\end{tabular}


Table 2-6. Variables related to total annual volumetric balances in postprocessing phase of MAIN program.

\begin{tabular}{|c|c|c|}
\hline Variable name & Size & Description \\
\hline pptyr & scalar & Total precipitation for all cells for the year, in millimeters. \\
\hline rainyr & scalar & Total precipitation as rain for all cells for the year, in millimeters. \\
\hline sncvyr & scalar & Total water-equivalent depth of snow for all cells for the year, in millimeters. \\
\hline meltyr & scalar & Total snowmelt for all cells for the year, in millimeters. \\
\hline atyr & scalar & Total air temperature for all cells for the year, in degrees Celsius. \\
\hline petyr & scalar & Total potential evapotranspiration adjusted for cloudy days for all cells for the year, in millimeters. \\
\hline pet2yr & scalar & Total unadjusted potential evapotranspiration for daily time step for all cells for the year, in millimeters. \\
\hline pet3yr & scalar & $\begin{array}{l}\text { Total approximation of potential evapotranspiration using vegetation cover, bare-soil area, and user-specified } \\
\text { Priestley-Taylor coefficient } \alpha \text { coefficients for all cells for the year, in millimeters. }\end{array}$ \\
\hline dswyr1 & scalar & $\begin{array}{l}\text { Total change in water content for all six model layers due to first step of flow routing for all cells for the year, } \\
\text { in millimeters. }\end{array}$ \\
\hline dswyr2 & scalar & $\begin{array}{l}\text { Total change in water content for all six model layers due to second step of flow routing for all cells for the year, } \\
\text { in millimeters. }\end{array}$ \\
\hline inf1yr & scalar & Total net infiltration due to first step of flow routing for all cells for the year, in millimeters. \\
\hline $\inf 2 y \mathbf{r}$ & scalar & Total net infiltration due to second step of flow routing for all cells for the year, in millimeters. \\
\hline inf3yr & scalar & Total daily net infiltration for all cells for the year, in millimeters. \\
\hline rinfyr & scalar & Total infiltrated run-on from previous day for the year, in millimeters. \\
\hline runyr & scalar & Total runoff generated for first step of flow routing for all cells for the year, in millimeters. \\
\hline
\end{tabular}


Table 2-7. Variables related to average annual volumetric balances for each cell in postprocessing phase of MAIN program.

\begin{tabular}{|c|c|c|}
\hline Variable name & Size & Description \\
\hline yearat & mxcells & Average annual air temperature for each cell, in degrees Celsius. \\
\hline yearrun & mxcells & Average annual runoff for second step of flow-routing algorithm for each cell, in millimeters. \\
\hline yearswin & mxcells & Average annual surface-water inflow to basin from upstream sources, in millimeters. \\
\hline yearppt & mxcells & Average annual precipitation for each cell, in millimeters. \\
\hline yearrain & mxcells & Average annual precipitation as rain for each cell, in millimeters. \\
\hline yearsnow & mxcells & Average annual precipitation as snow for each cell, in millimeters. \\
\hline yearsncv & mxcells & Average annual water-equivalent depth of snow for each cell, in millimeters. \\
\hline yearmelt & mxcells & Average annual snowmelt for each cell, in millimeters. \\
\hline yearsubl & mxcells & Average annual sublimation for each cell, in millimeters. \\
\hline yearpet2 & mxcells & Average annual unadjusted potential evapotranspiration for each cell, in millimeters. \\
\hline yearpet3 & mxcells & $\begin{array}{l}\text { Average annual approximation of potential evapotranspiration using vegetation cover, bare-soil area, and user- } \\
\text { specified Priestley-Taylor coefficient } \alpha \text { coefficients for each cell, in millimeters. }\end{array}$ \\
\hline yeartet & mxcells & Average annual total evapotranspiration from soil zone for each cell, in millimeters. \\
\hline yeardsw1 & mxcells & $\begin{array}{l}\text { Average annual change in water content for all six soil layers due to first step of flow routing for each cell, } \\
\text { in millimeters. }\end{array}$ \\
\hline yeardsw2 & mxcells & $\begin{array}{l}\text { Average annual change in water content for all six soil layers due to second step of flow routing for each cell, in } \\
\text { millimeters. }\end{array}$ \\
\hline yearinf1 & mxcells & Average annual net infiltration due to first step of flow routing for each cell, in millimeters. \\
\hline
\end{tabular}


Table 2-8. Variables related to long-term average annual volumetric balances for each location during averaging period of MAIN program.

\begin{tabular}{|c|c|c|}
\hline Variable name & Size & Description \\
\hline aainfr & mxcells & $\begin{array}{l}\text { Average annual change in water content for all six layers due to infiltration of run-on for each cell, } \\
\text { in millimeters. }\end{array}$ \\
\hline aaupflw & mxcells & Average annual surface-water inflow to basin from upstream sources, in millimeters. \\
\hline aappt & mxcells & Average annual precipitation for each cell, in millimeters. \\
\hline aarain & mxcells & Average annual precipitation as rain for each cell, in millimeters. \\
\hline aasnow & mxcells & Average annual precipitation as snow for each cell, in millimeters. \\
\hline aasncv & mxcells & Average annual water-equivalent depth of snow for each cell, in millimeters. \\
\hline aamelt & mxcells & Average annual snowmelt for each cell, in millimeters. \\
\hline aasubl & mxcells & Average annual sublimation for each cell, in millimeters. \\
\hline aatet & mxcells & Average annual total evapotranspiration from soil zone for each cell, in millimeters. \\
\hline aadsw2 & mxcells & $\begin{array}{l}\text { Average annual change in water content for all six soil layers due to second step of flow routing for each cell, } \\
\text { in millimeters. }\end{array}$ \\
\hline aapet & mxcells & $\begin{array}{l}\text { Average annual potential evapotranspiration adjusted for cloudy days and sublimation for each cell, } \\
\text { in millimeters. }\end{array}$ \\
\hline aapet2 & mxcells & Average annual unadjusted potential evapotranspiration for daily time step for each cell, in millimeters. \\
\hline aapet3 & mxcells & $\begin{array}{l}\text { Average annual approximation of potential evapotranspiration using vegetation cover, bare-soil area, and } \\
\text { user-specified Priestley-Taylor coefficient } \alpha \text { coefficients for each cell, in millimeters. }\end{array}$ \\
\hline aainf1 & mxcells & Average annual net infiltration due to first step of flow routing for each cell, in millimeters. \\
\hline aainf2 & mxcells & Average annual net infiltration due to second step of flow routing for each cell, in millimeters. \\
\hline aacfs & mxcells & Average annual runoff for second step of flow routing for each cell, in cubic feet per second. \\
\hline aacmd & mxcells & Average annual runoff for second step of flow routing for each cell, in cubic meters per day. \\
\hline cRun-Balance & scalar & Average annual mass-balance check for each cell, in millimeters. \\
\hline
\end{tabular}


Table 2-9. Variables related to global average annual volumetric balances for all cells in the simulation domain during averaging period of MAIN program.

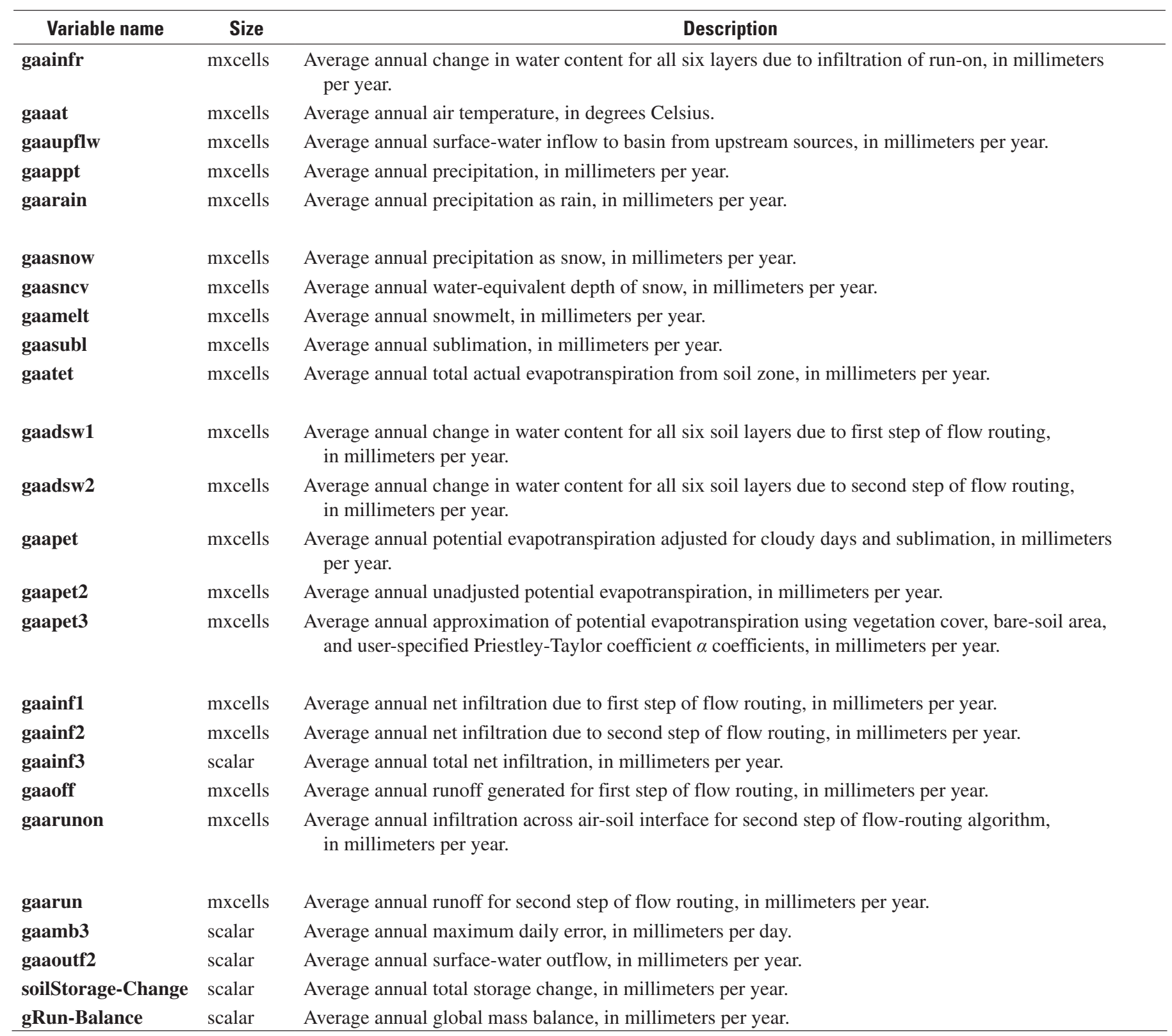




\section{SUBROUTINE RUNSRP}

Subroutine RUNSRP reads the total number of simulations to be made by INFIL3.0 and the names of the SimulationControl Files for each simulation from the batch-control file named infil3.ctl. Variables used in the subroutine are defined in table 2-10.

Table 2-10. Variables in subroutine RUNSRP.

[C* $\mathrm{n}$ in size column indicates a character variable of $n$ characters]

\begin{tabular}{ccc}
\hline Variable name & Size & \multicolumn{1}{c}{ Description } \\
\hline header & $\mathrm{C}^{*} 250$ & A character variable that can be used for a title for the set of simulations. \\
nruns & scalar & Total number of simulations to be made. A maximum of 100 simulations is allowed. \\
runfile & $\mathrm{C}^{*} 30$ & Name of simulation. A maximum of 100 names is allowed. \\
\hline
\end{tabular}

\section{SUBROUTINE CTLRP}

Subroutine CTLRP reads data from the Simulation-Control, Soil-Properties, Bedrock-Properties, Vegetation-Properties, and Monthly Atmospheric-Parameters Files. Variables used in the subroutine are defined in tables 2-11 through 2-15.

Table 2-11. Variables in subroutine CTLRP read from the Simulation-Control File.

[C* $\mathrm{n}$ in size column indicates a character variable of $n$ characters]

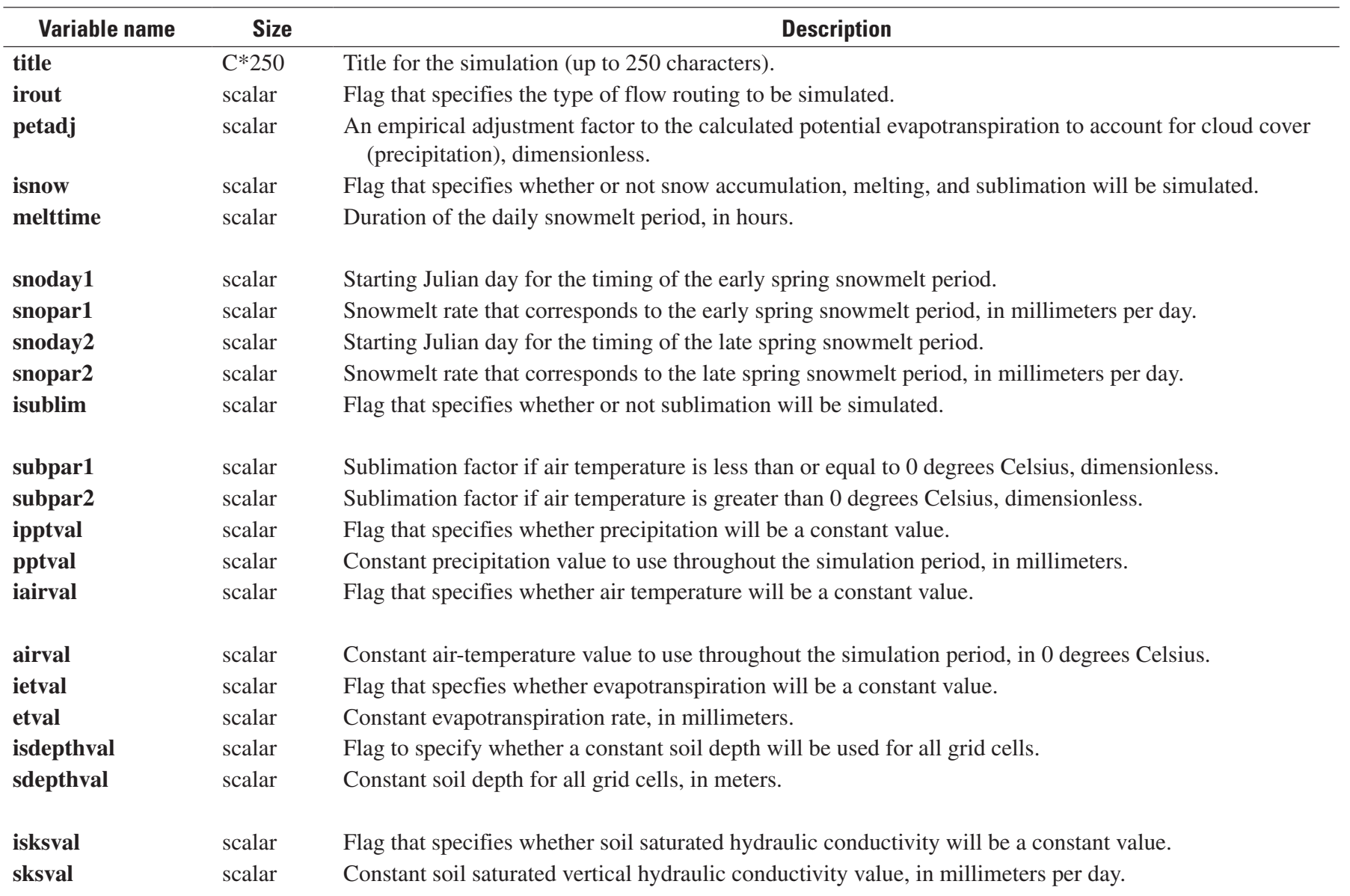


Table 2-11. Variables in subroutine CTLRP read from the Simulation-Control File.-Continued

[ $\mathrm{C}^{*} \mathrm{n}$ in size column indicates a character variable of $n$ characters]

\begin{tabular}{|c|c|c|}
\hline Variable name & Size & Description \\
\hline iimbval & scalar & $\begin{array}{l}\text { Flag that specifies whether bedrock unsaturated and saturated hydraulic conductivities will be a } \\
\text { constant value. }\end{array}$ \\
\hline imbval & scalar & Constant bedrock unsaturated and saturated hydraulic conductivities, in millimeters per day. \\
\hline celsize & scalar & Length of each side of each model grid cell, in meters. \\
\hline nupstream & scalar & Number of upstream basins contributing surface-water inflow. \\
\hline ioptupflow & 5 & Flag that specifies a constant rate of inflow for all days. \\
\hline upconst & 5 & Constant rate of inflow specified for upstream basin, in millimeters. \\
\hline upfile & 5 & Name of file containing daily upstream flow values. \\
\hline upgeoinp & 5 & Name of file containing upstream cellcode identifiers for cells contributing inflow. \\
\hline header & $\mathrm{C} * 250$ & Header line in file upgeoinp. \\
\hline cellcodeval & scalar & Location identifier for each grid cell. \\
\hline iupstream & 5 & $\begin{array}{l}\text { Last value of cellcode that is read from each upgeoinp file. All values in the iupstream array should be } \\
\text { equal; otherwise, the program will stop. }\end{array}$ \\
\hline $\begin{array}{l}\text { monthwy, } \\
\text { mondaywy }\end{array}$ & scalar & Month and day for which annual and average annual output will be calculated. \\
\hline $\begin{array}{l}\text { yrstart, mostart, } \\
\text { dystart }\end{array}$ & scalar & Year, month, and day of simulation start time. \\
\hline $\begin{array}{l}\text { yrend, moend, } \\
\text { dyend }\end{array}$ & scalar & Year, month, and day of simulation end time. \\
\hline $\begin{array}{l}\text { yrstart1, mostart1, } \\
\text { dystart1 }\end{array}$ & scalar & Year, month, and day of starting date to calculate simulation output flow averages. \\
\hline $\begin{array}{l}\text { yrend1, moend1, } \\
\text { dyend1 }\end{array}$ & scalar & Year, month, and day of ending date to calculate simulation output flow averages. \\
\hline output-Interval & scalar & Interval, in years, for which annual or average annual output will be printed. \\
\hline sdfact & scalar & Soil-depth scaling factor. \\
\hline pptfact & scalar & Precipitation scaling factor. \\
\hline etfact & scalar & Evapotranspiration scaling factor. \\
\hline imbfact & scalar & Bedrock unsaturated and saturated hydraulic conductivities scaling factor. \\
\hline sksfact & scalar & Soil saturated vertical hydraulic conductivity factor. \\
\hline ivegc & scalar & Flag for specifying vegetative-cover values. \\
\hline fvegc & scalar & Constant vegetation-cover value, in decimal percent. \\
\hline ichanmod & scalar & Flag for specifying how the wetted-flow area for each grid cell will be specified. \\
\hline chan1 & scalar & Surface-water minimum effective wetted-flow area, in decimal percent. \\
\hline chan2 & scalar & Surface-water wetted-flow area factor, dimensionless. \\
\hline chan3 & scalar & Surface-water maximum headwater wetted-flow area, dimensionless. \\
\hline chan4 & scalar & Surface-water maximum stream-channel wetted-flow area, dimensionless. \\
\hline ikschnmod & scalar & $\begin{array}{l}\text { Flag for specifying how soil saturated vertical hydraulic conductivity will be modified for stream-channel } \\
\text { locations. }\end{array}$ \\
\hline kschn1 & scalar & $\begin{array}{l}\text { Minimum number of upstream cells for adjusting the soil saturated vertical hydraulic conductivity, } \\
\text { dimensionless. }\end{array}$ \\
\hline kschn2 & scalar & Scaling factor for adjusting soil saturated vertical hydraulic conductivity in channels, dimensionless. \\
\hline kschn3 & scalar & $\begin{array}{l}\text { Maximum adjustment factor to the soil saturated vertical hydraulic conductivity in channels, } \\
\text { dimensionless. }\end{array}$ \\
\hline
\end{tabular}


Table 2-11. Variables in subroutine CTLRP read from the Simulation-Control File._Continued

[C*n in size column indicates a character variable of $n$ characters]

\begin{tabular}{|c|c|c|}
\hline Variable name & Size & Description \\
\hline barsoil1 & scalar & $\begin{array}{l}\text { Variable } \beta \text { in the modified Priestley-Taylor equation used for defining evaporation as a function of bare- } \\
\text { soil water content and potential evapotranspiration, dimensionless. }\end{array}$ \\
\hline barsoil2 & scalar & $\begin{array}{l}\text { Variable } \alpha \text { in the modified Priestley-Taylor equation used for defining evaporation as a function of bare- } \\
\text { soil water content and potential evapotranspiration, dimensionless. }\end{array}$ \\
\hline barsoilf & scalar & $\begin{array}{l}\text { An adjustment factor that can be used to modify the value of barsoil1 for layer } 2 \text { of the model, } \\
\text { dimensionless. }\end{array}$ \\
\hline rocket1 & scalar & $\begin{array}{l}\text { Variable } \beta \text { in the modified Priestley-Taylor equation used for defining transpiration as a function of rock- } \\
\text { matrix water content and potential evapotranspiration, dimensionless. }\end{array}$ \\
\hline rocket2 & scalar & $\begin{array}{l}\text { Variable } \alpha \text { in the modified Priestley-Taylor equation used for defining transpiration as a function of rock- } \\
\text { matrix water content and potential evapotranspiration, dimensionless. }\end{array}$ \\
\hline soilet1 & scalar & $\begin{array}{l}\text { Variable } \beta \text { in the modified Priestley-Taylor equation used for defining transpiration as a function of soil } \\
\text { water content and potential evapotranspiration, dimensionless. }\end{array}$ \\
\hline soilet2 & scalar & $\begin{array}{l}\text { Variable } \alpha \text { in the modified Priestley-Taylor equation used for defining transpiration as a function of soil } \\
\text { water content and potential evapotranspiration, dimensionless. }\end{array}$ \\
\hline hstep & scalar & Time-step length used for calculating total daily evapotranspiration, in hours. \\
\hline $\begin{array}{l}\text { dysumbeg, } \\
\text { dysumend }\end{array}$ & scalar & Beginning and ending Julian day number for summer storms. \\
\hline $\begin{array}{l}\text { stormsum, } \\
\text { stormwin }\end{array}$ & scalar & Duration of summer and winter storms, in hours. \\
\hline daystations & $\mathrm{C} * 30$ & Name of climate-stations information file. \\
\hline monthmod & $\mathrm{C} * 30$ & Name of monthly climate-regression models data file. \\
\hline daypptinput & $\mathrm{C} * 30$ & Name of daily precipitation data file. \\
\hline tunit & scalar & Flag to convert from degrees Fahrenheit to degrees Celsius. \\
\hline daytmax-input & $\mathrm{C} * 30$ & Name of daily maximum air-temperature data file. \\
\hline daytmin-input & $\mathrm{C} * 30$ & Name of daily minimum air-temperature data file. \\
\hline soilprop & $\mathrm{C} * 30$ & Name of soils-properties data file. \\
\hline rockprop & $\mathrm{C} * 30$ & Name of bedrock-properties data file. \\
\hline atmosinput & $\mathrm{C} * 30$ & Name of monthly atmospheric-parameters data file. \\
\hline vegprop & $\mathrm{C} * 30$ & Name of vegetation-properties data file. \\
\hline initopt & scalar & Flag for determining how initial soil-water content conditions will be set. \\
\hline vwcfact & scalar & Multiplication factor for setting initial soil-water content for each of the 5 soil layers. \\
\hline restartfile & $\mathrm{C} * 30$ & $\begin{array}{l}\text { Name of file with several mass-balance terms for each grid cell for the last successful day of a previous } \\
\text { simulation. }\end{array}$ \\
\hline ndayscrash & scalar & Last day of successful simulation in a previous simulation that corresponds to data in file restartfile. \\
\hline infile & $\mathrm{C} * 30$ & Name of Geospatial Watershed-Characteristics data file. \\
\hline crashfile & $\mathrm{C} * 30$ & $\begin{array}{l}\text { Name of program crash file to hold several mass-balance terms for each grid cell for the last successful } \\
\text { day of a simulation. }\end{array}$ \\
\hline dayall & $\mathrm{C} * 30$ & $\begin{array}{l}\text { Name of file for output of spatially averaged output terms for all grid cell locations for each successive } \\
\text { day of a simulation. }\end{array}$ \\
\hline ndaymap & scalar & Number of daily output files of mass-balance results for each grid cell. \\
\hline irday, nyrout & 100 & $\begin{array}{l}\text { Sequential number of day (irday) and the year (nyrout) to write daily mass-balance results to a cor- } \\
\text { responding daymap file. }\end{array}$ \\
\hline daymap & $\mathrm{C} * 30$ & $\begin{array}{l}\text { Name of file for output of daily mass-balance terms for each grid cell for specific days identified by } \\
\text { irday and nyrout. A maximum of } 100 \text { files may be listed. }\end{array}$ \\
\hline
\end{tabular}


Table 2-11. Variables in subroutine CTLRP read from the Simulation-Control File.-Continued

[ $\mathrm{C}^{*} \mathrm{n}$ in size column indicates a character variable of $n$ characters]

\begin{tabular}{|c|c|c|}
\hline Variable name & Size & Description \\
\hline pointfile(1) & $\mathrm{C} * 30$ & $\begin{array}{l}\text { Name of file for ouput of daily mass-balance terms corresponding to the last active grid cell in the model } \\
\text { area (that is, the cell immediately above the outflow cell). }\end{array}$ \\
\hline ipointfilte & scalar & Number of additional output files of daily mass-balance terms at specific grid cells. \\
\hline xpoint, ypoint & 20 & $\begin{array}{l}\text { East-west (easting; xpoint) and north-south (northing; ypoint) coordinates of grid cell for output file of } \\
\text { daily mass-balance terms. }\end{array}$ \\
\hline pointfile & $\mathrm{C} * 30$ & $\begin{array}{l}\text { Name of file for output of daily mass-balance terms corresponding to current xpoint, ypoint. A maxi- } \\
\text { mum of } 20 \text { files may be listed. }\end{array}$ \\
\hline outfile & $\mathrm{C} * 30$ & $\begin{array}{l}\text { Name of output file with summary information for the simulation, as well as summary statistics for the } \\
\text { entire simulation. }\end{array}$ \\
\hline flxfile & $\mathrm{C}^{*} 30$ & Name of output file with average annual mass-balance terms during averaging period for each grid cell. \\
\hline spatialout & $\mathrm{C} * 30$ & Name of output file to which summary information about spatial properties for each grid cell is written. \\
\hline outyear 1 & $\mathrm{C} * 26$ & $\begin{array}{l}\text { Prefix of the name of the output file for mass-balance terms for annual totals or multiyear averages by } \\
\text { grid cell. }\end{array}$ \\
\hline outannual & $\mathrm{C} * 30$ & Name of file to hold total annual flow terms for the entire grid. \\
\hline outmonth & $\mathrm{C}^{*} 30$ & Name of file to hold total monthly flow terms for the entire grid. \\
\hline
\end{tabular}

Soil properties are read from file soilprop, which is defined for each simulation in the Simulation-Control File. Variables that are read from this file are defined in table 2-12.

Table 2-12. Variables read from Soil-Properties File.

[ $\mathrm{C}^{*} \mathrm{n}$ in size column indicates a character variable of $n$ characters]

\begin{tabular}{|c|c|c|}
\hline Variable name & Size & Description \\
\hline header & $\mathrm{C} * 250$ & A character variable that can be used for a title for the file. \\
\hline nsoilid & scalar & Number of soil types to be entered. \\
\hline soilid & scalar & Integer variable used to identify the soil-type number. \\
\hline soilmu & $\mathrm{C} * 12$ & Name of the soil type. \\
\hline soilporo & mxprop & Soil porosity, dimensionless. \\
\hline fieldcap & mxprop & Soil field capacity, dimensionless. \\
\hline soilresid & mxprop & Residual soil-water content for plant transpiration, which is also referred to as the wilting point, dimensionless. \\
\hline soilb & mxprop & Soil drainage function coefficient, dimensionless. \\
\hline Soilks1 & scalar & Saturated vertical hydraulic conductivity of the soil, in millimeters per day. \\
\hline isksval & scalar & Flag that specifies whether soil saturated vertical hydraulic conductivity will be a constant value. \\
\hline sksval & scalar & Constant soil saturated vertical hydraulic conductivity value, in millimeters per day. \\
\hline soilks & mxprop & Saturated vertical hydraulic conductivity of the soil, in millimeters per day. \\
\hline soilet1 & scalar & $\begin{array}{l}\text { Variable } \beta \text { in the modified Priestley-Taylor equation used for defining transpiration as a function of soil-water } \\
\text { content and potential evapotranspiration, dimensionless. }\end{array}$ \\
\hline soilet2 & scalar & $\begin{array}{l}\text { Variable } \alpha \text { in the modified Priestley-Taylor equation used for defining transpiration as a function of soil-water } \\
\text { content and potential evapotranspiration, dimensionless. }\end{array}$ \\
\hline soilalbeta & mxprop & $\begin{array}{l}\text { Variable } \beta \text { in the modified Priestley-Taylor equation used for defining transpiration as a function of soil-water } \\
\text { content and potential evapotranspiration, dimensionless. }\end{array}$ \\
\hline soiltalpha & mxprop & $\begin{array}{l}\text { Variable } \alpha \text { in the modified Priestley-Taylor equation used for defining transpiration as a function of soil-water } \\
\text { content and potential evapotranspiration, dimensionless. }\end{array}$ \\
\hline
\end{tabular}


Bedrock and deep alluvium properties are read from file rockprop, which is defined for each simulation in the SimulationControl file. Variables that are read from this file are defined in table 2-13.

Table 2-13. Variables read from Rock-Properties File.

[C*n in size column indicates a character variable of $n$ characters]

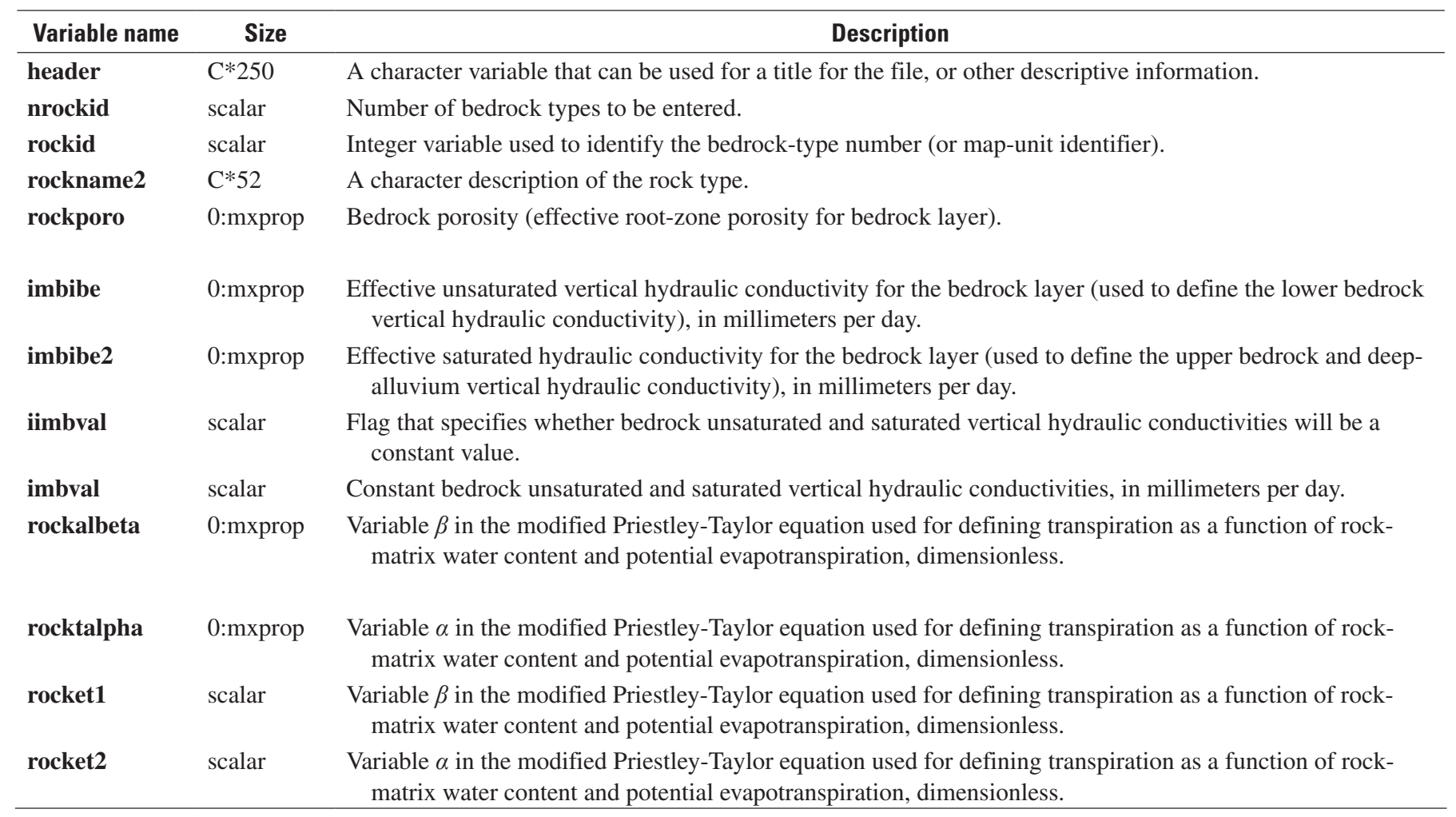

Vegetation properties are read from file vegprop, which is defined for each simulation in the Simulation-Control File. Variables that are read from this file are defined in table 2-14.

Table 2-14. Variables read from Vegetation-Properties File.

[C*n in size column indicates a character variable of $n$ characters]

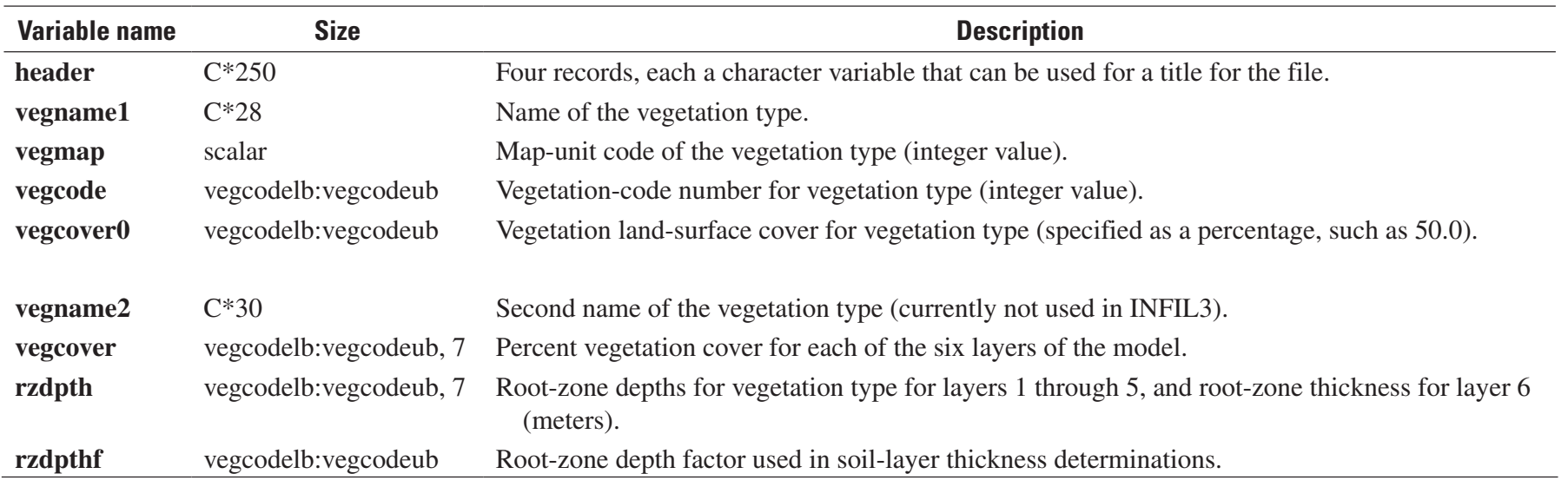


Monthly atmospheric variables are read from file atmosinput, which is defined for each simulation in the SimulationControl File. Records are read for each of the 12 months of the year. Variables that are read from this file are defined in table 2-15.

Table 2-15. Variables read from Monthly Atmospheric-Parameters File.

[C* $\mathrm{n}$ in size column indicates a character variable of $n$ characters]

\begin{tabular}{lll}
\hline Variable name & Size & \\
\hline header & C 250 & Four records, each a character variable that can be used for a title for the file. \\
iii & scalar & Month number, 1 for January, 2 for February, and so forth. \\
ozone & 12 & Ozone-layer thickness for month, in centimeters. \\
wp & 12 & Precipitable water in the atmosphere for month, in centimeters. \\
beta & 12 & Mean atmospheric turbidity for month, dimensionless. \\
csr & 12 & Circumsolar radiation for month, dimensionless. \\
pg & 12 & Surface reflectivity for month, dimensionless. \\
\hline
\end{tabular}

\section{SUBROUTINE STATIONSRP}

Subroutine STATIONSRP reads information about the climate stations that provide climate data for a simulation. Information for the subroutine is read from file daystations, which is defined for each simulation in the Simulation-Control File. Variables used in the subroutine are defined in table 2-16.

Table 2-16. Variables in subroutine STATIONSRP.

[C* $\mathrm{n}$ in size column indicates a character variable of $n$ characters]

\begin{tabular}{|c|c|c|}
\hline Variable name & Size & Description \\
\hline header & $\mathrm{C} * 256$ & A character variable that can be used for a title for the dataset. \\
\hline name & $\mathrm{C}^{*} 28, \mathrm{mxstations}$ & Name of each climate station. \\
\hline statid & mxstations & An integer-variable code for each climate station. \\
\hline eutm & mxstations & East-west coordinate (easting) of each climate station, in meters. \\
\hline nutm & mxstations & North-south coordinate (northing) of each climate station, in meters. \\
\hline statelev & mxstations & Elevation of each climate station, in meters. \\
\hline
\end{tabular}




\section{SUBROUTINE MMPARAMRP}

Subroutine MMPARAMRP reads information about the data from the monthly climate-regression models and calculates estimated monthly climate variables (precipitation and maximum and minimum air temperature) for the climate stations. Information for the subroutine is read from file monthmod, which is defined for a specific simulation in the Simulation-Control File. Variables used in the subroutine are defined in table 2-17.

Table 2-17. Variables in subroutine MMPARAMRP.

[C*n in size column indicates a character variable of $n$ characters]

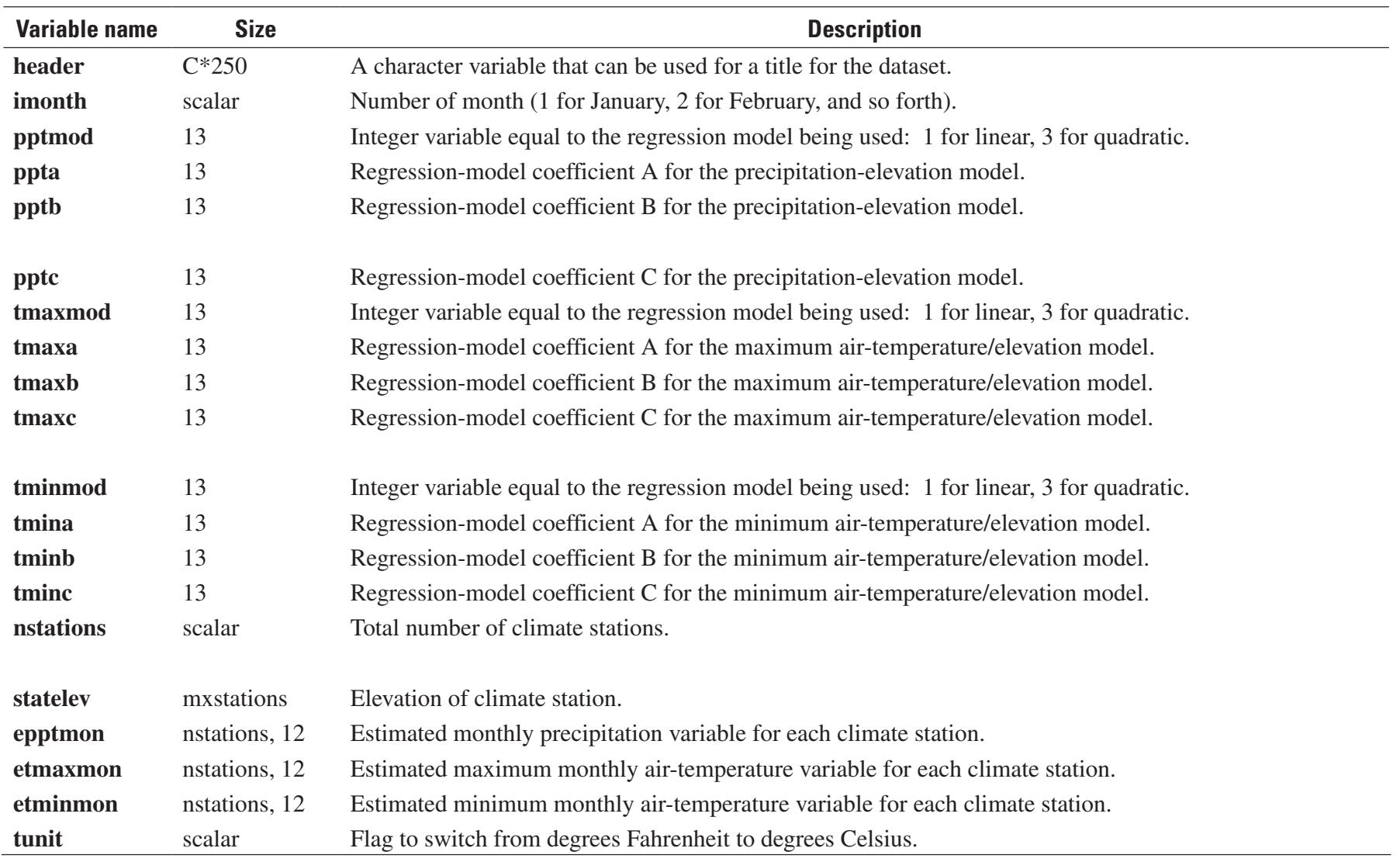




\section{SUBROUTINE CLIMATEDATARP}

Subroutine CLIMATEDATARP reads daily precipitation and maximum and minimum air-temperature values for each climate station. Climate data are read from files daypptinput, daytmaxinput, and daytmininput. The subroutine also is used to set starting and ending dates for the model simulation. Variables used in the subroutine are defined in table 2-18.

Table 2-18. Variables in subroutine CLIMATEDATARP.

[C* $\mathrm{n}$ in size column indicates a character variable of $n$ characters]

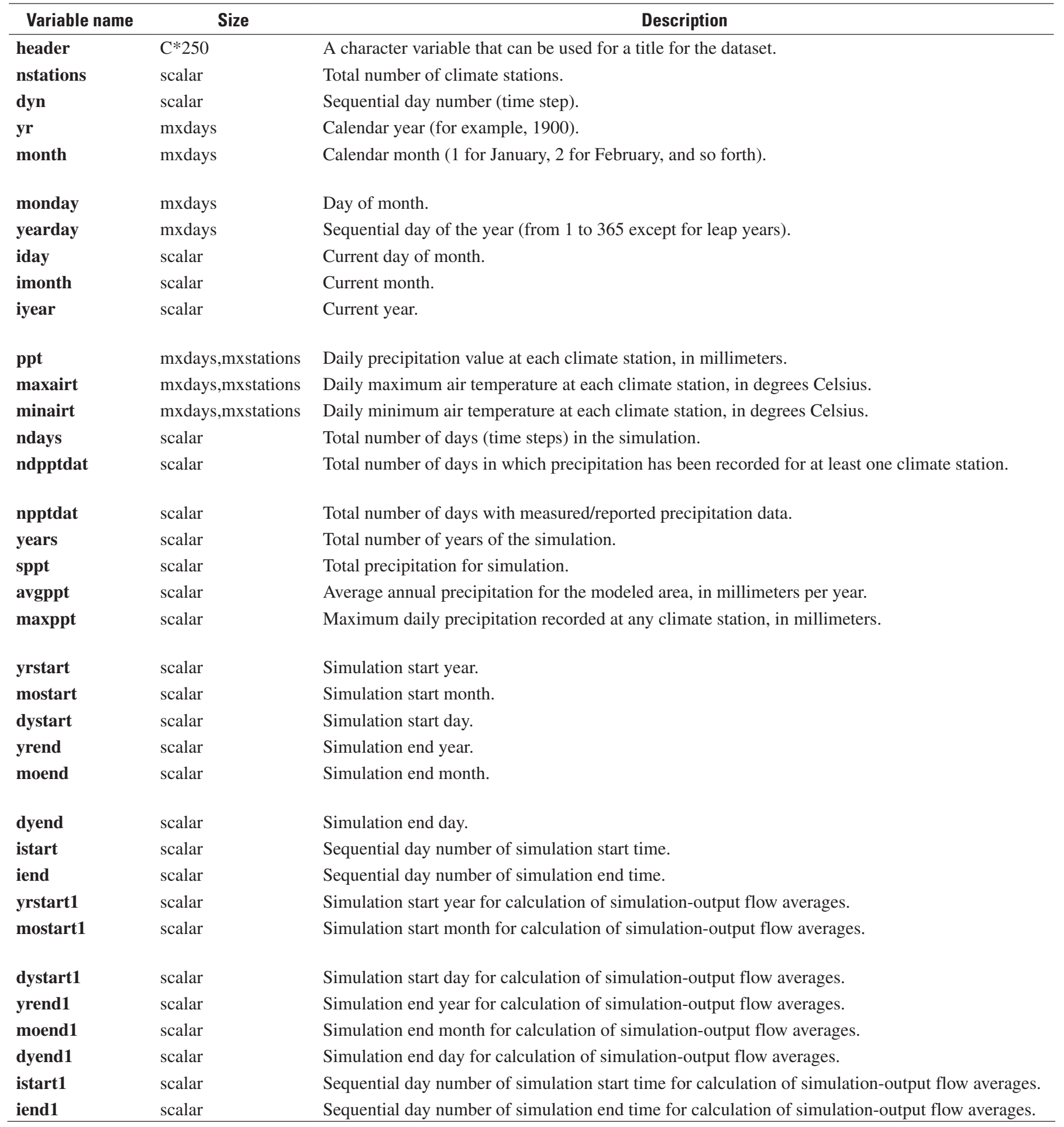




\section{SUBROUTINE UPSTREAMRP}

Subroutine UPSTREAMRP reads daily surface-water inflows for each subbasin that contributes flow to the simulated basin. Surface-water inflows are read for each subbasin from file upfile. The contents of upfile are the same as the contents of the pointfile that is generated as part of the INFIL simulation output for subbasins. The only values from upfile that are actually used by INFIL are those for variables dyn and upinput(51), which are the simulation time step and surface-water-inflow value, respectively. Variable upinput(51) is made equal to variable swinflw(mxdays,5), which is defined with the other variables for the subroutine in table 2-19.

Table 2-19. Variables in subroutine UPSTREAMRP.

[C*n in size column indicates a character variable of $n$ characters]

\begin{tabular}{lll}
\hline Variable name & \multicolumn{1}{c}{ Size } & \multicolumn{1}{c}{ Description } \\
\hline $\begin{array}{l}\text { header } \\
\text { dyn }\end{array}$ & $\begin{array}{l}\mathrm{C} * 256 \\
\text { scalar }\end{array}$ & $\begin{array}{l}\text { A character variable that can be used for a title for the dataset. } \\
\text { Sequential day number (time step). }\end{array}$ \\
$\begin{array}{l}\text { ioptupflow } \\
\text { upconst }\end{array}$ & 53 & $\begin{array}{l}\text { Array of flow and storage terms from upstream basin; the only variable of interest to the subroutine is } \\
\text { upinput(51), which is the surface-water-inflow value. } \\
\text { upfig that specifies a constant rate of inflow for all days. }\end{array}$ \\
swinflw & 5 & $\begin{array}{l}\text { Constant rate of inflow specified for upstream basin, in millimeters. } \\
\text { Name of file containing daily upstream flow values. }\end{array}$ \\
\hline
\end{tabular}

\section{SUBROUTINE GEOSPATIALRP}

Subroutine GEOSPATIALRP reads spatial coordinates and other watershed information about each grid cell, calculates average watershed characteristics for the modeled area, and calculates layer thicknesses for each grid cell. Information for the subroutine is read from file infile, which is defined for each simulation in the Simulation-Control File. Variables used in the subroutine are defined in table 2-20.

Table 2-20. Variables in subroutine GEOSPATIALRP.

[C*n in size column indicates a character variable of $n$ characters]

\begin{tabular}{lll}
\hline \multicolumn{1}{c}{ Variable name } & \multicolumn{1}{c}{ Size } & \multicolumn{1}{c}{ Description } \\
\hline $\begin{array}{l}\text { header } \\
\text { nloc } \\
\text { ncell } \\
\text { ssl }\end{array}$ & $\mathrm{C} * 250$ & A character variable that can be used for a title for the dataset. \\
scalar & Total number of grid cells. \\
avgsl & scalar & Total number of active grid cells (those with variable iwat not equal to -3). \\
scalar & Total slope of all active grid cells, degrees. \\
maxsl & scalar & Average slope of all active grid cells, degrees. \\
selev & scalar & Maximum slope of all active grid cells, degrees. \\
avgelev & scalar & Total elevation of all active grid cells, in meters. \\
maxelev & scalar & Average elevation of all active grid cells, in meters. \\
minelev & scalar & Maximum elevation of all active grid cells, in meters. \\
scalar & Minimum elevation of all active grid cells, in meters. \\
locid & mxcells & Location identifier for each grid cell. \\
cellcode & mxcells & Integer variable equal to the grid-cell (node) number. \\
easting & mxcells & East-west (easting) coordinate of the centroid of the grid cell, in meters. \\
northing & mxcells & North-south (northing) coordinate of the centroid of the grid cell, in meters.
\end{tabular}


Table 2-20. Variables in subroutine GEOSPATIALRP.—Continued

[C* $\mathrm{n}$ in size column indicates a character variable of $n$ characters]

\begin{tabular}{|c|c|c|}
\hline Variable name & Size & Description \\
\hline lat & mxcells & Latitude of the centroid of each grid cell. \\
\hline lon & mxcells & Longitude of the centroid of each grid cell. \\
\hline col & mxcells & Cell assignment for each grid cell. \\
\hline iwat & mxcells & $\begin{array}{l}\text { Integer variable equal to the downstream location identifier to which runoff is directed from the } \\
\text { current cell (iwat }=-3 \text { indicates the outflow cell of the basin). }\end{array}$ \\
\hline sl & mxcells & Land-surface slope of the centroid of each grid cell, degrees. \\
\hline asp & mxcells & Land-surface aspect of the centroid of each grid cell, degrees azimuth relative to north. \\
\hline upcells & mxcells & Total number of upstream cells that contribute flow to the current grid cell. \\
\hline rocktype & mxcells & Integer code for the bedrock type of each grid cell. \\
\hline vegtype & mxcells & Integer code for the vegetation type of each grid cell. \\
\hline skyview & mxcells & Total fraction of viewable sky, as fraction of hemisphere, dimensionless. \\
\hline ridge & mxcells, 36 & Blocking ridge angles (36) for each grid cell. \\
\hline isdepthval & scalar & Flag to specify whether a constant soil depth will be used for all grid cells. \\
\hline sdepthval & scalar & Constant soil depth for all grid cells, in meters. \\
\hline sdfact & scalar & Soil-depth scaling factor. \\
\hline imbibe & 0:mxprop & $\begin{array}{l}\text { Effective unsaturated vertical hydraulic conductivity for the bedrock layer (used to define the lower } \\
\text { bedrock hydraulic conductivity). }\end{array}$ \\
\hline $\begin{array}{l}\text { rdepth1, } \ldots \text {, } \\
\text { rdepth6 }\end{array}$ & scalar & Root-zone depth for layers 1 through layer 5 and root-zone thickness for layer 6 , in meters. \\
\hline rdepthf & scalar & Root-zone depth factor used in soil-layer thickness determinations. \\
\hline cdepth & 6, mxcells & Layer thickness for layers 1 through 6 , in meters. \\
\hline xcfs & scalar & East-west coordinate of basin outflow cell (iwat $=-3$ cell), in meters. \\
\hline ycfs & scalar & North-south coordinate of basin outflow cell (iwat $=-3$ cell), in meters. \\
\hline xpoint(1) & 20 & East-west coordinate of basin outflow cell (iwat $=-3$ cell), in meters. \\
\hline ypoint(1) & 20 & North-south coordinate of basin outflow cell (iwat $=-3$ cell), in meters. \\
\hline avgdepth & scalar & Average soil depth of all active grid cells, in meters. \\
\hline avglaythck & 10 & Average layer thickness for each of the six model layers for all grid cells, in meters. \\
\hline avgimbibe & scalar & $\begin{array}{l}\text { Average unsaturated (lower) vertical hydraulic conductivity of bedrock for all grid cells, } \\
\text { in millimeters per day. }\end{array}$ \\
\hline avgimbibe2 & scalar & $\begin{array}{l}\text { Average saturated (higher) hydraulic conductivity of bedrock for all grid cells, in millimeters } \\
\text { per day. }\end{array}$ \\
\hline
\end{tabular}




\section{SUBROUTINE ATMOS}

Subroutine ATMOS calculates daily atmospheric variables that are subsequently used in subroutine POTEVAP for solarradiation calculations. The calculations for each of the daily atmospheric terms are based on a linear interpolation of values between the middle of each successive month. For example, the daily values for January 15 are equal to the monthly value for January and values for dates between January 1 and 14 are weighted between values for January and December. Variables used in the subroutine are defined in table 2-21.

Table 2-21. Variables in subroutine ATMOS.

\begin{tabular}{lcl}
\hline Variable name & Size & \multicolumn{1}{c}{ Description } \\
\hline ozone & 12 & Ozone-layer thickness for month, in centimeters. \\
wp & 12 & Precipitable water in the atmosphere for month, in centimeters. \\
beta & 12 & Mean atmospheric turbidity for month, dimensionless. \\
csr & 12 & Circumsolar radiation for month, dimensionless. \\
pg & 12 & Surface reflectivity for month, dimensionless. \\
& & \\
ozone0 & 366 & Daily ozone-layer thickness, in centimeters. \\
wp0 & 366 & Daily precipitable water in the atmosphere, in centimeters. \\
beta0 & 366 & Daily mean atmospheric turbidity, dimensionless. \\
csr0 & 366 & Daily circumsolar radiation, dimensionless. \\
pg0 & 366 & Daily surface reflectivity, dimensionless. \\
\hline
\end{tabular}

\section{SUBROUTINES SPDATAINIT and OUTPUTINIT}

Subroutines SPDATAINIT and OUTPUTINIT are used to initialize several of the water-budget variables that are used in INFIL computations. Most of the variables that are initialized in these subroutines are defined in tables 2-2 through 2-9, 2-11 and 2-12, or 2-20, and their definitions can be found in those tables. Variables that are not defined previously are defined in table 2-22.

Table 2-22. Variables in subroutines SPDATAINIT and OUTPUTINIT not defined previously.

\begin{tabular}{|c|c|c|}
\hline Variable name & Size & Description \\
\hline scapmm1, ..., scapmm5 & scalar & Initial storage capacity of each soil layer of the grid cell, in millimeters. \\
\hline rkmm & scalar & Initial storage capacity of the bedrock layer, in millimeters. \\
\hline soilvwe & mxcells & Initial soil-water contents for the five soil layers, dimensionless. \\
\hline skmm & scalar & Saturated vertical hydraulic conductivity of the soil, in millimeters per day. \\
\hline imb2 & scalar & $\begin{array}{l}\text { Effective unsaturated vertical hydraulic conductivity for the bedrock layer (used to define the lower } \\
\text { bedrock vertical hydraulic conductivity), in millimeters per year. }\end{array}$ \\
\hline tet & scalar & Total evapotranspiration, in millimeters. \\
\hline
\end{tabular}




\section{SUBROUTINE DAYDIST}

Subroutine DAYDIST distributes daily precipitation and air-temperature data across the model domain by monthly precipitation-elevation and air temperature-elevation regression models combined with an inverse-distance-squared interpolation algorithm. The subroutine calculates for each grid cell daily precipitation, maximum and minimum daily air temperatures, and average daily air temperature. Variables used in the subroutine are defined in table 2-23.

Table 2-23. Variables in subroutine DAYDIST.

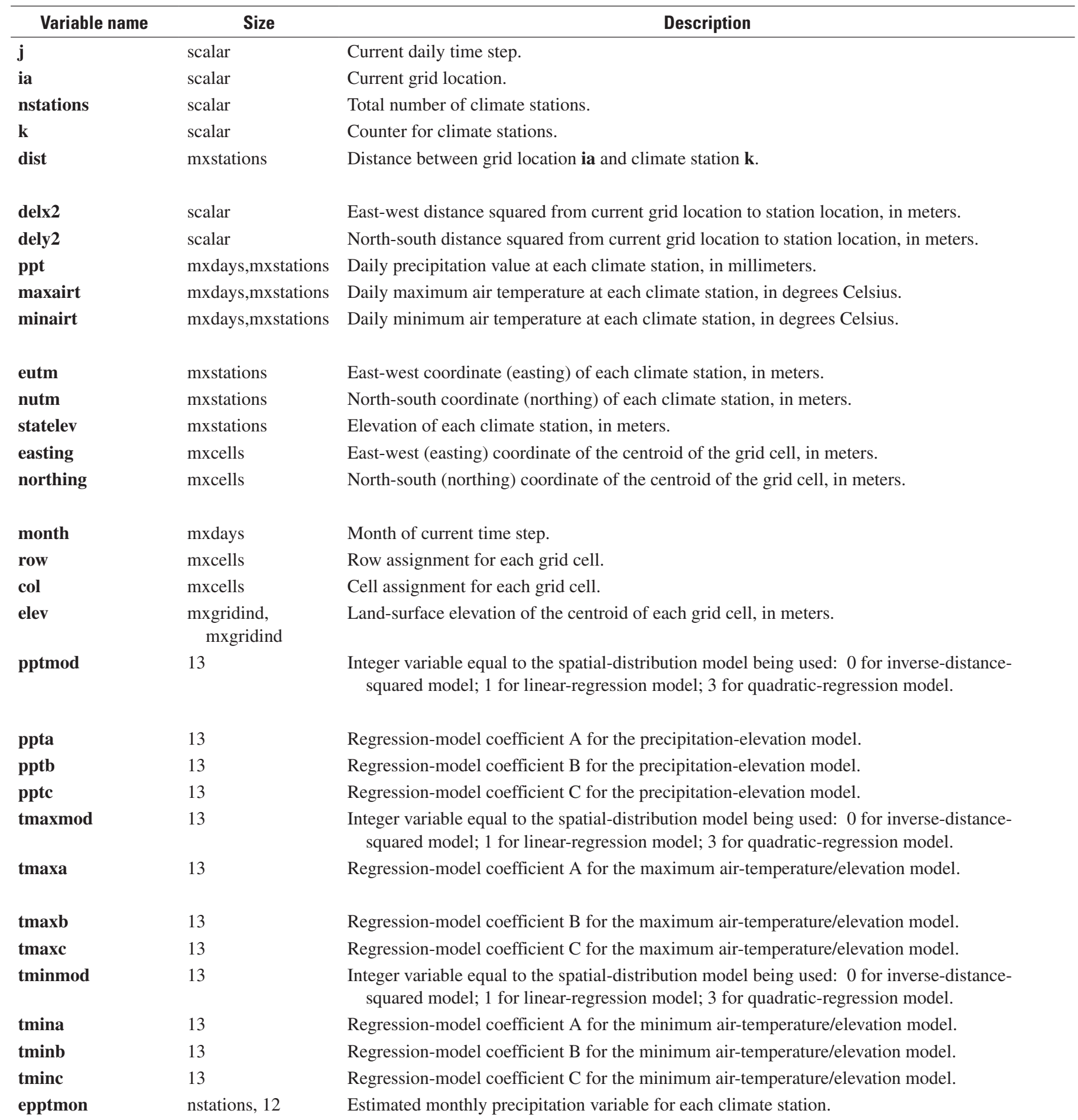


Table 2-23. Variables in subroutine DAYDIST._Continued

\begin{tabular}{|c|c|c|}
\hline Variable name & Size & Description \\
\hline etmaxmon & nstations, 12 & Estimated maximum monthly air temperature variable for each climate station. \\
\hline etminmon & nstations, 12 & Estimated minimum monthly air temperature variable for each climate station. \\
\hline $\begin{array}{l}\text { sdistppt, sdisttmax, } \\
\text { sdisttmin }\end{array}$ & scalar & $\begin{array}{l}\text { Sum of the distances between grid location ia and each of the climate stations that have values } \\
\text { for precipitation (sdistppt), maximum air temperature (sdisttmax), and minimum air tempera- } \\
\text { ture (sdisttmin). }\end{array}$ \\
\hline eppt1 & scalar & Estimated precipitation for grid cell, in millimeters. \\
\hline etmax & scalar & Estimated maximum air temperature for grid cell, in degrees Celsius. \\
\hline etmin & scalar & Estimated minimum air temperature for grid cell, in degrees Celsius. \\
\hline pptloc00 & scalar & Estimated precipitation for grid cell, in millimeters. \\
\hline
\end{tabular}

\section{SUBROUTINE POTEVAP}

Subroutine POTEVAP calculates daily solar radiation, net radiation, and potential evapotranspiration for each grid cell for each day. The primary output of the subroutine is a value of the daily potential evapotranspiration (variable tpet0) for a cell. Variables used in the subroutine are defined in table 2-24.

Table 2-24. Variables in subroutine POTEVAP.

\begin{tabular}{|c|c|c|}
\hline Variable name & Size & Description \\
\hline $\mathbf{j}$ & scalar & Current daily time step. \\
\hline ia & scalar & Current grid location. \\
\hline yearday & mxdays & Sequential day of the year (from 1 to 365 except for leap years). \\
\hline lat & mxcells & Latitude of the centroid of each grid cell. \\
\hline lon & mxcells & Longitude of the centroid of each grid cell. \\
\hline sl & mxcells & Slope of the centroid of each grid cell, degrees. \\
\hline row & mxcells & Row assignment for each grid cell. \\
\hline col & mxcells & Cell assignment for each grid cell. \\
\hline asp & mxcells & Aspect of the centroid of each grid cell, degrees azimuth relative to north. \\
\hline $\operatorname{csr} 0$ & 366 & Daily circumsolar radiation, dimensionless. \\
\hline pg0 & 366 & Daily surface reflectivity (albedo of ground or ground cover), dimensionless. \\
\hline airtemp & scalar & Average air temperature for grid cell, in degrees Celsius. \\
\hline ydn & scalar & Sequential day of the year (from 1 to 365 except for leap years). \\
\hline std & scalar & Standard meridian of the site, in degrees. \\
\hline lat2 & mxcells & Latitude of the centroid of each grid cell in radians. \\
\hline
\end{tabular}


Table 2-24. Variables in subroutine POTEVAP.-Continued

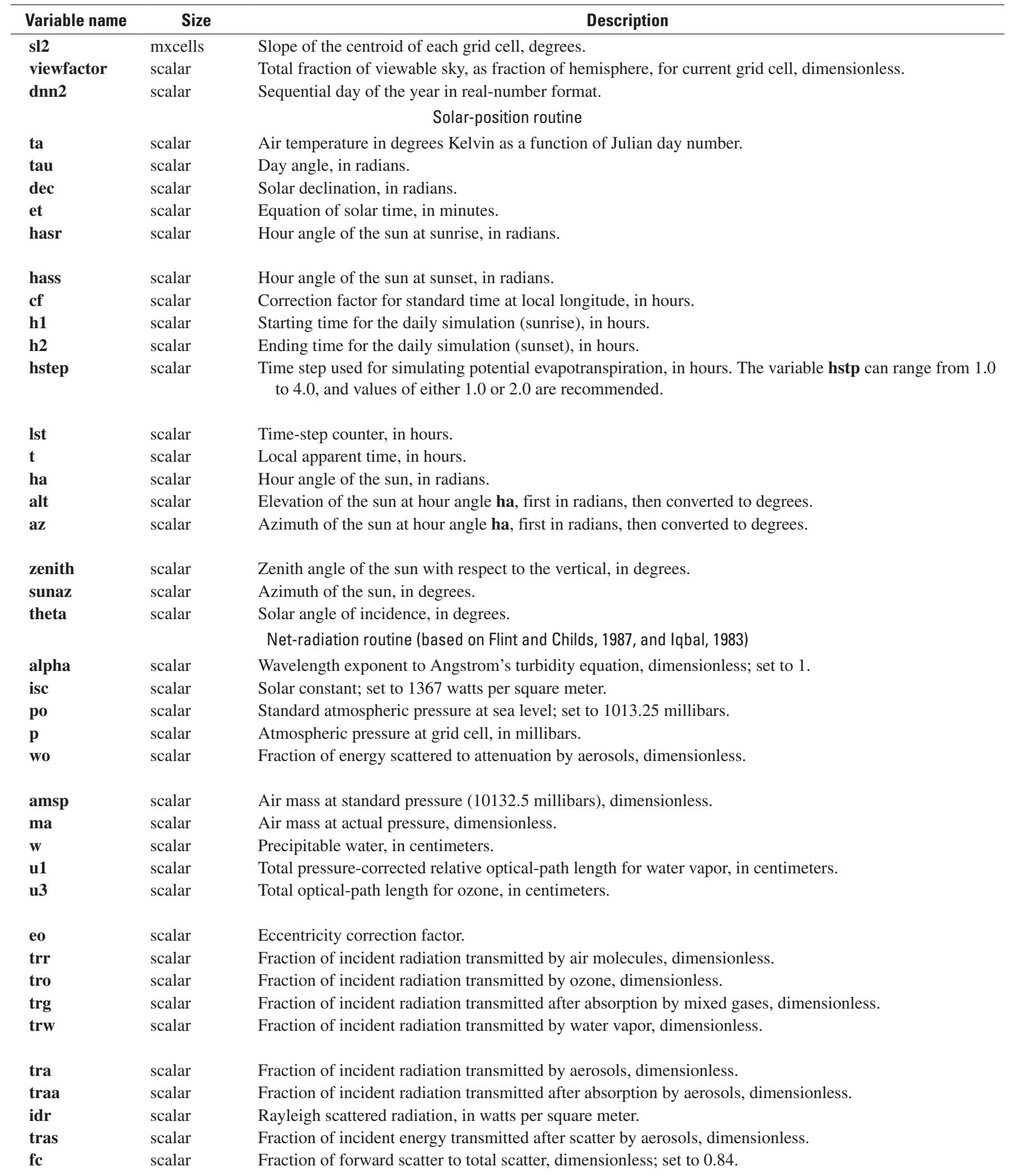


Table 2-24. Variables in subroutine POTEVAP._Continued

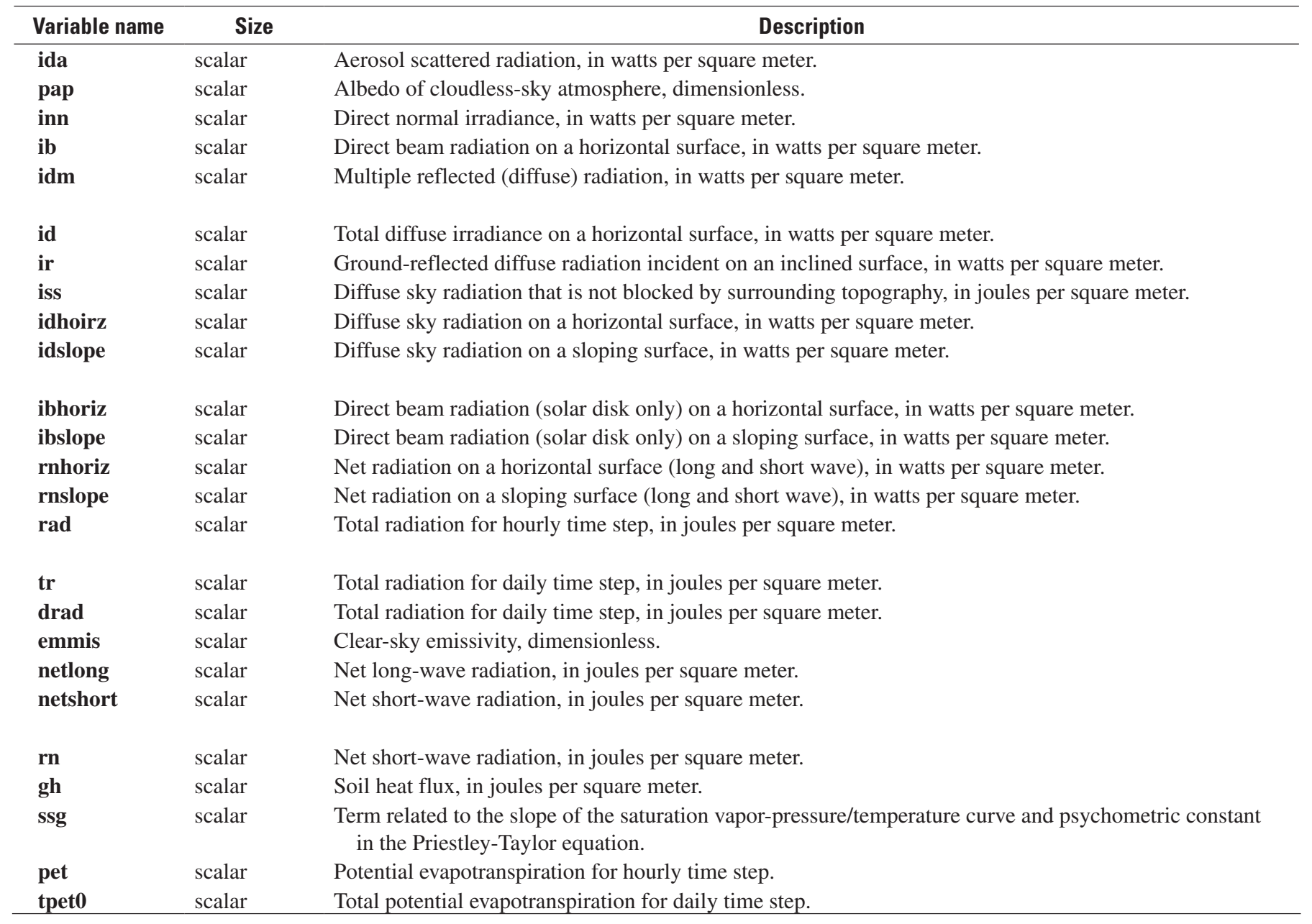




\section{SUBROUTINE SNOW}

Subroutine SNOW calculates daily snowfall (or rain), water-equivalent depth of snow, snowmelt, and sublimation for each grid cell for each day. Variables used in the subroutine are defined in table 2-25.

Table 2-25. Variables in subroutine SNOW.

\begin{tabular}{|c|c|c|}
\hline Variable name & Size & Description \\
\hline $\mathbf{j}$ & scalar & Current daily time step. \\
\hline ia & scalar & Current grid location. \\
\hline ydn & scalar & Sequential day of the year (from 1 to 365 except for leap years). \\
\hline airtemp & scalar & Average air temperature, in degrees Celsius. \\
\hline pptloc & mxcells & Precipitation, in millimeters. \\
\hline rain & mxcells & Precipitation as rain, in millimeters. \\
\hline snowfall & mxcells & Precipitation as snow, in millimeters. \\
\hline snowmm & mscells & Water-equivalent depth of snow, in millimeters. \\
\hline snopar1 & scalar & Snowmelt-rate variable that corresponds to the early-spring snowmelt period. \\
\hline snopar2 & scalar & Snowmelt-rate variable that corresponds to the late-spring snowmelt period. \\
\hline isublim & scalar & $\begin{array}{l}\text { Flag that specifies whether or not sublimation will be simulated: isublim }=1 \text { indicates that sublimation } \\
\text { will be calculated. }\end{array}$ \\
\hline petrs & mxcells & Adjusted potential evapotranspiration, in millimeters. \\
\hline subpar1 & scalar & Sublimation variable 1 , for temperatures less than or equal to freezing (dimensionless). \\
\hline subpar2 & scalar & Sublimation variable 2 , for temperatures greater than freezing (dimensionless). \\
\hline sublim & mxcells & Sublimation, in millimeters. \\
\hline dsnowev & scalar & Change in water-equivalent depth of snow, in millimeters. \\
\hline
\end{tabular}




\section{SUBROUTINE ETINFIL}

Subroutine ETINFIL is the primary subroutine that calculates root-zone water balance. The subroutine has four primary functions: (1) calculation of infiltration to the root zone from rain and snowmelt and an initial calculation of runoff equal to rain and snowmelt in excess of the infiltration capacity of the soil or bedrock; (2) redistribution of infiltration by downward drainage through all layers of the root zone and an initial calculation of the change in soil-water storage in each layer of the root zone; (3) calculation of evapotranspiration from each layer of the root zone; and (4) final calculations of infiltration below the root zone, change in soil-water storage in each layer of the root zone, and runoff from the grid cell. As part of the fourth function, ETINFIL is the first step in the two-step flow-routing algorithm of INFIL3.0. Variables used in the subroutine are defined in table 2-26.

Table 2-26. Variables in subroutine ETINFIL.

\begin{tabular}{|c|c|c|}
\hline Variable name & Size & Description \\
\hline $\mathbf{j}$ & scalar & Current daily time step. \\
\hline ia & scalar & Current grid location. \\
\hline yearday & mxdays & Sequential day of the year (from 1 to 365 except for leap years). \\
\hline ydn & scalar & Sequential day of the year (from 1 to 365 except for leap years). \\
\hline drmm1, .., drmm6 & scalar & Total drainage for layers $1(\mathbf{d r m m} \mathbf{1})$ through $6(\mathbf{d r m m} \mathbf{r})$ for cell, in millimeters. \\
\hline ivegc & scalar & Flag for specifying vegetative-cover values. \\
\hline vegc0 & scalar & Vegetation land-surface cover for vegetation type (specified as a percentage, such as 50.0). \\
\hline vegc1, ..., vegc6 & scalar & Percent vegetation cover for each of the six layers of the model. \\
\hline fvegc & scalar & Constant vegetation-cover value, in decimal percent. \\
\hline a & scalar & $\begin{array}{l}\text { Variable } \alpha \text { in the modified Priestley-Taylor equation used for defining evapotranspiration as } \\
\text { a function of soil-water content and potential evapotranspiration. }\end{array}$ \\
\hline $\mathbf{b}$ & scalar & $\begin{array}{l}\text { Variable } \beta \text { in the modified Priestley-Taylor equation used for defining evapotranspiration as } \\
\text { a function of soil water content and potential evapotranspiration. }\end{array}$ \\
\hline a3 & scalar & $\begin{array}{l}\text { Variable } \alpha \text { in the modified Priestley-Taylor equation used for defining evapotranspiration as } \\
\text { a function of rock-matrix water content and potential evapotranspiration, for rock type rockid. }\end{array}$ \\
\hline b3 & scalar & $\begin{array}{l}\text { Variable } \beta \text { in the modified Priestley-Taylor equation used for defining evapotranspiration as } \\
\text { a function of rock-matrix water content and potential evapotranspiration, for rock type rockid. }\end{array}$ \\
\hline a2 & scalar & $\begin{array}{l}\text { Variable } \alpha \text { in the modified Priestley-Taylor equation used for defining evaporation as a function of } \\
\text { bare-soil water content and potential evapotranspiration. }\end{array}$ \\
\hline b2 & scalar & $\begin{array}{l}\text { Variable } \beta \text { in the modified Priestley-Taylor equation used for defining evaporation as a function of } \\
\text { bare-soil water content and potential evapotranspiration. }\end{array}$ \\
\hline imb & scalar & $\begin{array}{l}\text { Effective unsaturated vertical hydraulic conductivity for the bedrock layer (used to define the lower } \\
\text { bedrock vertical hydraulic conductivity), in millimeters per day. }\end{array}$ \\
\hline imb2 & scalar & $\begin{array}{l}\text { Effective saturated vertical hydraulic conductivity for the bedrock layer (used to define the upper } \\
\text { bedrock and deep-alluvium vertical hydraulic conductivity), in millimeters per day. }\end{array}$ \\
\hline skmm & scalar & Vertical hydraulic conductivity of the soil, in millimeters per day. \\
\hline dysumbeg & scalar & Beginning Julian day number for summer storms. \\
\hline dysumend & scalar & Ending Julian day number for summer storms. \\
\hline skmmp & scalar & $\begin{array}{l}\text { Modified saturated vertical hydraulic conductivity (rain infiltration capacity) of the soil to account } \\
\text { for storm duration, in millimeters per day. }\end{array}$ \\
\hline stormsum & scalar & Duration of summer storms, in hours. \\
\hline imbp & scalar & $\begin{array}{l}\text { Modified saturated vertical hydraulic conductivity (rain infiltration capacity) of the bedrock to } \\
\text { account for storm duration, in millimeters per day. }\end{array}$ \\
\hline stormwin & scalar & Duration of winter storms, in hours. \\
\hline skmelt & scalar & $\begin{array}{l}\text { Modified saturated vertical hydraulic conductivity (snowmelt infiltration capacity) of the soil to } \\
\text { account for a snowmelt event, in millimeters per day. }\end{array}$ \\
\hline
\end{tabular}


Table 2-26. Variables in subroutine ETINFIL.-Continued

\begin{tabular}{|c|c|c|}
\hline Variable name & Size & Description \\
\hline rkmelt & scalar & $\begin{array}{l}\text { Modified saturated vertical hydraulic conductivity (snowmelt infiltration capacity) of the combined } \\
\text { rock matrix and fractures to account for a snowmelt event, in millimeters per day. }\end{array}$ \\
\hline fieldcp & scalar & Soil field capacity, dimensionless. \\
\hline fcmm $1, \ldots$, fcmm6 & scalar & Equivalent depth of field capacity for each layer, in millimeters. \\
\hline cdepth & 6, mxcells & Layer thickness for layers 1 through 6 , in meters. \\
\hline rkmm & scalar & Equivalent depth of rock porosity, in millimeters. \\
\hline rkpor & scalar & Porosity of rock, dimensionless. \\
\hline spor & scalar & Porosity of soil, dimensionless. \\
\hline sresid & scalar & Residual soil-water content for cell, dimensionless. \\
\hline epor & scalar & $\begin{array}{l}\text { Effective porosity, which is the difference between the porosity and residual water content of the } \\
\text { soil, dimensionless. }\end{array}$ \\
\hline totmm & scalar & Total equivalent depth of porosity for all six model layers, in millimeters. \\
\hline resmm1, ..., resmm6 & scalar & Equivalent depth of residual soil-water content for each layer, in millimeters. \\
\hline infilmm1 & mxcells & Infiltration below root zone for current cell, in millimeters. \\
\hline runoffmm & mxcells & Runoff for current cell, in millimeters. \\
\hline initmm & scalar & Initial water content of all six soil layers of model cell, in millimeters. \\
\hline rinfmm1 & mxcells & Change in water content for all six layers due to infiltration of run-on for each cell, in millimeters. \\
\hline finalmm & scalar & Final water content of all six soil layers of model cell, in millimeters. \\
\hline dsoilmm1 & mxcells & Difference between final and initial water content of all six soil layers of model cell, in millimeters. \\
\hline rainin & scalar & Precipitation as rain, in millimeters. \\
\hline rainout & scalar & Precipitation in excess of rain infiltration capacity of soil, in millimeters. \\
\hline meltin & scalar & Amount of snowmelt, in millimeters. \\
\hline meltout & scalar & Snowmelt in excess of snowmelt infiltration capacity, in millimeters. \\
\hline soilinf & scalar & Sum of infiltrated rain and snowmelt into soil, in millimeters. \\
\hline soilb & mxprop & Soil drainage function coefficient. \\
\hline gn & scalar & Modified soil drainage function coefficient. \\
\hline gb & scalar & Inverse of modified soil drainage function coefficient. \\
\hline drmm & scalar & Total drainage for current layer, in millimeters. \\
\hline vwc1, ..., vwc5 & scalar & $\begin{array}{l}\text { Dimensionless volumetric soil-water content for each layer, equal to soil-water content (in mil- } \\
\text { limeters) divided by thickness of layer (in meters) and by the conversion factor 1,000 millimeters } \\
\text { per meter. }\end{array}$ \\
\hline relsat $1, \ldots$, relsat5 & scalar & Relative saturation for each layer, dimensionless. \\
\hline soilmm & 5, mxcells & Soil water content for each soil layer, in millimeters. \\
\hline
\end{tabular}


Table 2-26. Variables in subroutine ETINFIL.—Continued

\begin{tabular}{|c|c|c|}
\hline Variable name & Size & Description \\
\hline soilmm1, ..., soilmm5 & scalar & Soil water content for each soil layer, in millimeters. \\
\hline rockmm & mxcells & Rock water content, in millimeters. \\
\hline ga1, ..., ga5 & scalar & Coefficients for layers 1 (ga1) through 5 (ga5) in the empirical drainage function. \\
\hline gc1, ..., gc5 & scalar & Coefficients for layers 1 (gc1) through 5 (gc5) in the empirical drainage function. \\
\hline vwc11, ..., vwc51, & scalar & Coefficients for layers 1 (vwc11) through 5 (vwc51) in the empirical drainage function. \\
\hline vwc12, ..., vwc52, & scalar & Coefficients for layers $1(\mathbf{v w c 1 2})$ through $5(\mathbf{v w c 5 2})$ in the empirical drainage function. \\
\hline vwc13, ..., vwc53, & scalar & Coefficients for layers 1 (vwc13) through $5(\mathbf{v w c 5 3})$ in the empirical drainage function. \\
\hline rockinf & scalar & Infiltration into bedrock, in millimeters. \\
\hline petrs3 & scalar & $\begin{array}{l}\text { Updated potential evapotranspiration, in millimeters. This potential evaporation is equal to the } \\
\text { adjusted rate of potential evapotranspiration accounting for days on which there is precipitation } \\
\text { minus sublimation and minus the total amount of evaporation and transpiration that occurs from } \\
\text { all model layers in the subroutine. }\end{array}$ \\
\hline barsoilf & scalar & An adjustment factor that can be used to modify the value of $\mathbf{b} 2$ used for layer 1 . \\
\hline totsat & scalar & Total relative saturation of all six layers, dimensionless. \\
\hline wgt1, ..., wgt2 & scalar & Weighting functions for each model layer for use in modified Priestley-Taylor equation. \\
\hline et1, ..., et6 & scalar & Transpiration from each of the six model layers, in millimeters. \\
\hline et & $(6$, mxcells $)$ & Actual evapotranspiration from each model layer, in millimeters. \\
\hline
\end{tabular}




\section{SUBROUTINE SWINFIL}

Subroutine SWINFIL is the second step of the flow-routing algorithm. In this step, runoff is routed to downstream cells as surface-water run-on. Run-on can infiltrate back into the root zone and contribute to the total daily net-infiltration rate. Variables used in the subroutine are defined in table 2-27.

Table 2-27. Variables in subroutine SWINFIL.

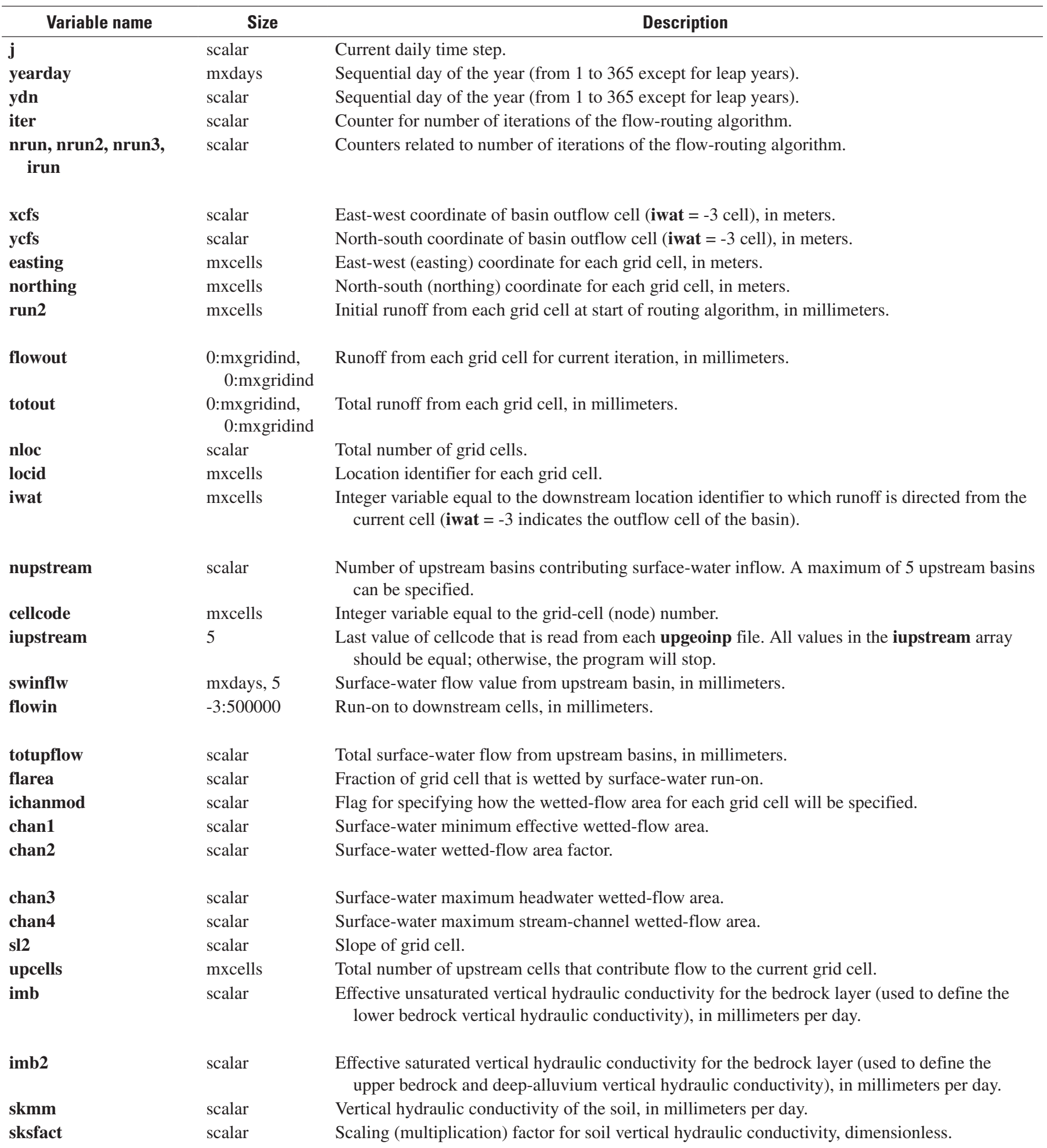


Table 2-27. Variables in subroutine SWINFIL.-Continued

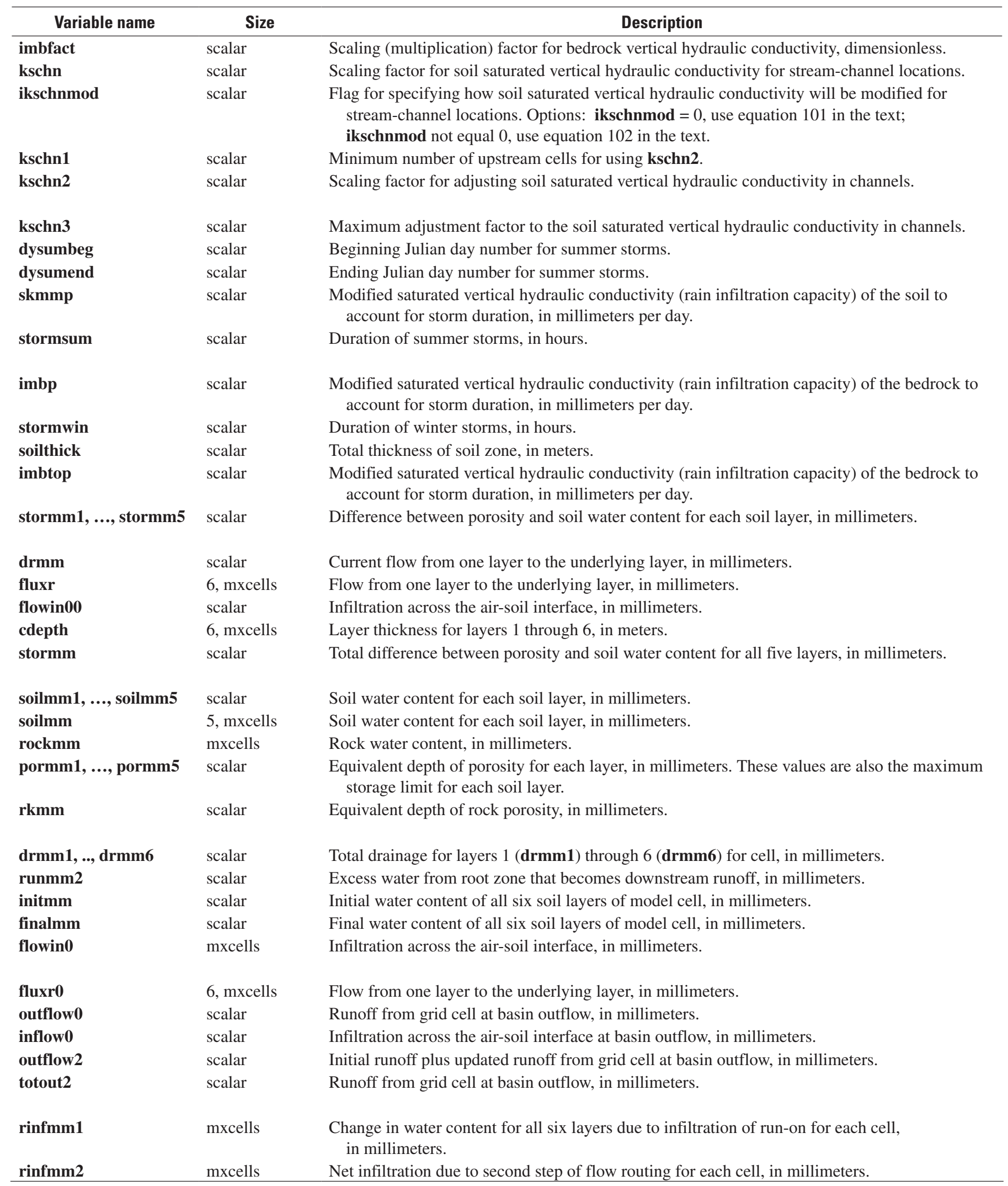


Prepared by the Pembroke Publishing Service Center

For more information concerning the research in this report, contact:

Office of Ground Water

U.S. Geological Survey

411 National Center

Reston, VA 20192

(703) 648-5001 
